\title{
EL PRINCIPIO DE PUBLICIDAD EN LA ACTIVIDAD CONTRACTUAL DEL ESTADO. PERSPECTIVA DE LA TRANSPARENCIA.
}

\section{LUIS FRANCISCO VELANDIA VENEGAS}

\section{TESIS}

Con el propósito de obtener el título de

Magíster en Derecho Público

Directora de Investigación

PhD. CORINA DUQUE AYALA

UNIVERSIDAD SANTO TOMAS

UNIVERSIDAD KONSTANZ

Bogotá, 2016 


\section{Agradecimientos}

A mi tutora Dra. Corina Duque Ayala, por sus sabios consejos y trascendentales aportes que permitieron desarrollar esta tesis.

A mis padres, por su incondicional apoyo, en las metas que me propongo.

A mi hermana, por su invaluable e inquebrantable compañía.

A mi querida sobrina, que con su frase 'la manía de mi tío, en el computador', lograba desconectarme para compartir su infancia y sonrisas. 


\section{Índice}

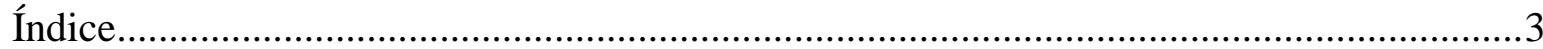

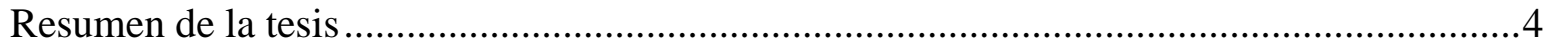

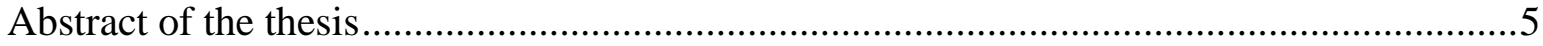

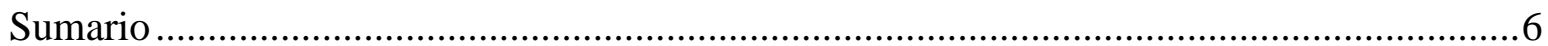

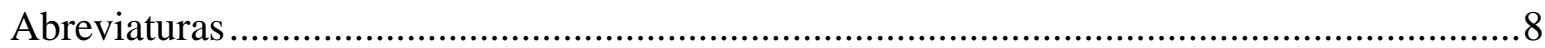

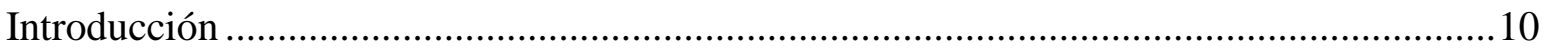

Primera Parte: Evolución del Contrato en la Administración Pública....................................24

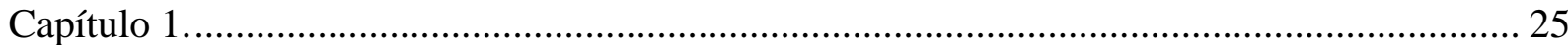

Antecedentes en los Contratos de la Administración .............................................................. 25

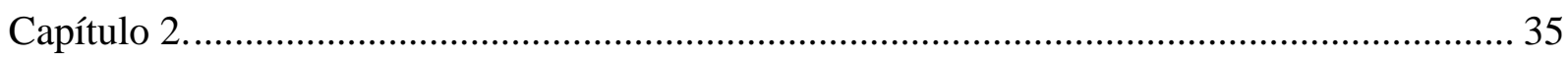

El Contrato de la Administración Pública en la Ley 80 de 1993 ............................................. 35

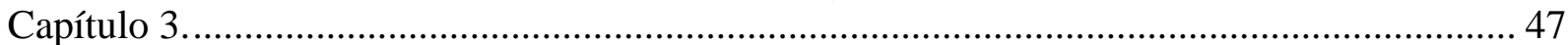

Las Reformas en el Marco de Probidad a partir de la Ley 1150 de 2007 ................................. 47

Segunda Parte: La Actividad Contractual Pública en el Estado Colombiano ........................61

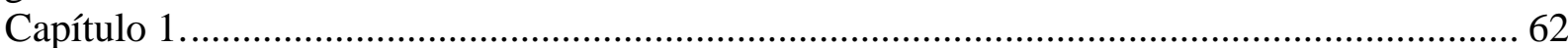

El Paradigma del Principio de Transparencia en la Ley 80 de 1993 ......................................... 62

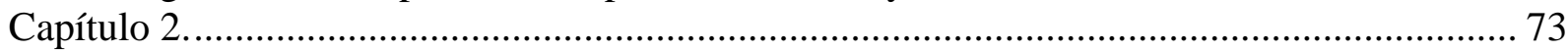

Resultados del Fortalecimiento al Principio de Transparencia en las Compras Públicas......... 73

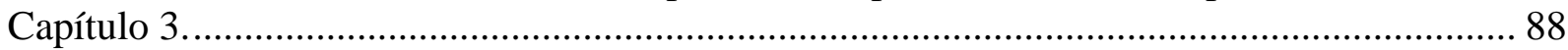

Prácticas que afectan la Transparencia en la Actividad Contractual Pública ........................... 88

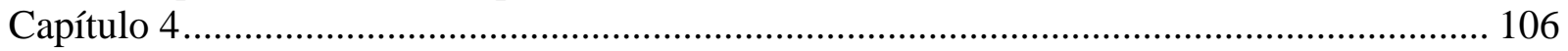

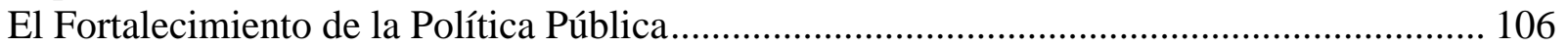

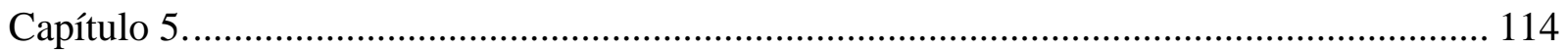

Incidencia de las Buenas Prácticas en las Compras Públicas .............................................. 114

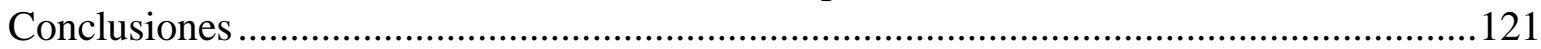

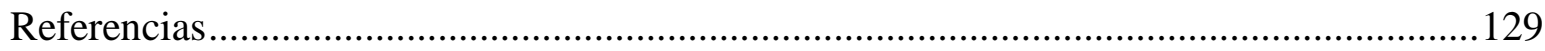

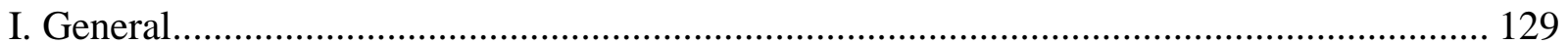

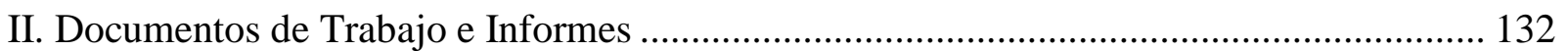

III. Legislación, Disposiciones, Reglamentos y otros documentos ...................................... 136

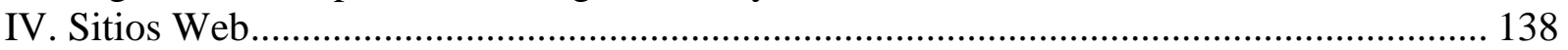

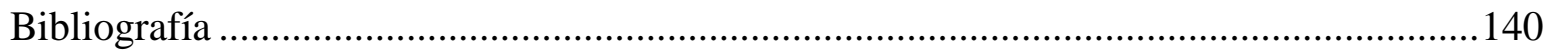

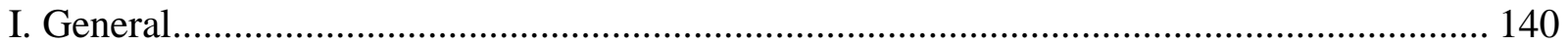

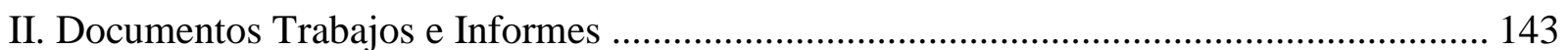

Notas 
Resumen de la tesis

\section{EL PRINCIPIO DE PUBLICIDAD EN LA ACTIVIDAD CONTRACTUAL DEL ESTADO. PERSPECTIVA DE LA TRANSPARENCIA}

En la primera parte, se analizará la evolución del contrato de la administración en Colombia, desde las relaciones originadas en virtud del derecho ordinario, época en que prevalecían actos de poder que permitían la libre disposición de recursos públicos, para continuar en un período de profusión normativa, caracterizado por disposiciones contractuales que diferían de un ente público a otro; y finalizar con el estudio del Estatuto General de Contratación de la Administración Pública y sus modificaciones.

En la segunda parte, se analizará el paradigma del principio de transparencia en el texto primigenio del Estatuto General de Contratación de la Administración Pública; para continuar con los resultados de las medidas de fortalecimiento en la actividad contractual del Estado; y culminar con la identificación de prácticas individuales y sociales que afectan la transparencia en la gestión.

Por último, se plantea, a partir del análisis normativo de las experiencias internacionales, de las prácticas de los diferentes actores en los procesos de contratación pública y de la jurisprudencia, unas conclusiones en busca de una posible solución al problema propuesto.

Palabras clave: Contrato estatal, legalidad, publicidad, transparencia, probidad, corrupción, prácticas. 


\section{Abstract of the thesis}

\section{THE PUBLICITY PRINCIPLE OF CONTRACTUAL ACTIVITY OF STATE. PERSPECTIVE ON TRANSPARENCY ACTIONS.}

In first section, contract evolution on the management in Colombia will be analyzed from the relationship created on the basis of the ordinary right, period in which power acts prevailed, that allowed free disposition of public resources, and then to continue into profusion of regulations, characterized by contractual rules that differed from a public entity with regard to another one; and finally, to deal with a study on General Statute of Contracting of Civil Service and its modification.

In the second section, the transparency principle paradigm of the original text General Statute of Contracting of Civil Service will be analyzed, to go on with results of the strengthening forms in contractual activity of State, and to end with identification of individual and social performances that affect the transparency action.

Finally, conclusions are considered in search of a possible solution for a suggested problem, from regulation analysis about international experiences, from performances of different actors in the public contracting and jurisprudence processes.

Keywords: state contracting, legality, publicity, transparency, probity, corruption, performances. 


\section{Sumario}

Índice

Resumen

Sumario

Abreviaturas

Introducción

Primera Parte: Evolución del Contrato en la Administración Pública

Capítulo 1. Antecedentes en los Contratos de la Administración

Capítulo 2. El Contrato de la Administración Pública en la Ley 80 de 1993

Capítulo 3. Las Reformas en el Marco de Probidad a partir de la Ley 1150 de 2007

Segunda Parte: La Actividad Contractual Pública en el Estado Colombiano

Capítulo 1. El Paradigma del Principio de Transparencia en la Ley 80 de 1993

Capítulo 2. Resultados del Fortalecimiento al Principio de Transparencia en las Compras Públicas

Capítulo 3. Prácticas que afectan la Transparencia en la Actividad Contractual Pública

Capítulo 4. El Fortalecimiento de la Política Pública

Capítulo 5. Incidencia de las Buenas Prácticas en las Compras Públicas

Conclusiones

Referencias

Bibliografía

Notas 


\section{Gráficas y Tablas}

Gráfica No. 1 - Nivel de Corrupción en el Gobierno Departamental

Gráfica No. 2 - Riesgos de Corrupción en Entidades Descentralizadas

Gráfica No. 3 - Nivel de Publicidad en la Contratación Departamental

Gráfica No. 4 - Índice de Corrupción - Gobierno Municipal

Gráfica No. 5 - Riesgos de Corrupción

Gráfica No. 6 - Ofrecimiento de Sobornos por Empresarios

Gráfica No. 7 - Influencia de Pagos Extraoficiales

Gráfica No. 8 - Porcentajes de Participación en Licitaciones

Tabla No. 1 - Índice de Percepción de Corrupción 2007

Tabla No. 2 - Índice de Percepción de Corrupción 2012 
ACP Acuerdo sobre Contratación Pública

BID Banco interamericano de Desarrollo

CBS Clasificador de Bienes y Servios

CEPAL Comisión Económica para América Latina y el Caribe

$\mathrm{CCl} \quad$ Cámara Colombiana de Infraestructura

CIACC Convención Interamericana contra la Corrupción

CIIU Clasificación Industrial Internacional Uniforme

CNUCC Convención de las Naciones Unidas contra la Corrupción

CNUDMI Comisión de las Naciones para el Derecho Mercantil Internacional

CONPES Consejo Nacional de Política Económica y Social

CPAR Informe de Evaluación de Adquisiciones del país

DANE Departamento Administrativo de Planeación

DAPRE Departamento administrativo de la Presidencia de la Republica

EACA Empresas Activas en Cumplimiento Anticorrupción

ECDE Encuesta de Calidad de la Gestión Estatal para el Desarrollo Empresarial. (DANE)

IDRC Centro Internacional de Investigaciones para el Desarrollo

ítd Índice de Transparencia Departamental

ítm Índice de Transparencia Municipal

ítn Índice de Transparencia Nacional

K Capacidad de contratación

Mipymes Micro, pequeñas y medianas empresas

OCDE Organización para la Cooperación y Desarrollo Económicos

OEA Organización de Estados Americanos

OMC Organización Mundial del Comercio

PIB Producto Interno Bruto

PPIA Política Pública Integra Anticorrupción

Pymes Pequeñas y medianas empresas 


$\begin{array}{ll}\text { RICG } & \text { Red Interamericana de Compras Gubernamentales } \\ \text { SECOP } & \text { Sistema Electrónico para la Contratación Pública } \\ \text { SELA } & \text { Sistema Económico Latinoamericano y del Caribe } \\ \text { TI } & \text { Transparencia Internacional } \\ \text { TIC } & \text { Tecnologías de la Información y las Comunicaciones } \\ \text { UE } & \text { Unión Europea } \\ \text { UNCITRAL } & \text { Ley Modelo sobre la Contratación Pública de la Comisión de Naciones } \\ & \text { Unidas para el Derecho Mercantil }\end{array}$




\section{Introducción}

El panorama en la actividad contractual gubernamental, es constantemente cuestionado por los organismos internacionales y por la sociedad civil, con la intención de lograr que los gobiernos incorporen instrumentos que posibiliten la transparencia y pulcritud de la mencionada gestión pública, por situaciones en las que predominan, irregularidades en los procedimientos para la escogencia del futuro contratista y deficiencias en la ejecución contractual, por fenómenos asociados con actos de corrupción.

La Organización Mundial del Comercio $(O M C)$ señaló que la contratación pública se omitió inicialmente en los instrumentos comerciales multilaterales, lo cual conllevó a restricciones discriminatorias que dieron lugar a un primer intento, por la Organización de Cooperación de Desarrollo Económico (OCDE), de incluirla en las disposiciones de comercio internacional, por su importante representación en el Producto Interno Bruto (PIB) que oscilaba entre el $10 \%$ y $15 \% .^{1}$

En consecuencia, las compras públicas forman parte de la agenda multilateral del comercio desde 1979, cuando se firmó el Código de la Ronda de Tokio sobre Compras del Sector Público, el cual estableció el marco internacional convenido de derechos, obligaciones, procedimientos y prácticas relativas a las compras públicas, que se adoptó el 15 de abril de 1994 en el marco de la Ronda de Uruguay, mediante el Acuerdo sobre Contratación Pública - ACP.2

El ACP como instrumento jurídico de la Organización Mundial del Comercio (OMC) resulta vinculante solo para los países que lo suscriban por ser plurilateral y se estructura en dos segmentos: El texto del acuerdo y las listas de compromisos entre las partes en materia de acceso a los mercados. En su contenido desarrolla específicamente el tema de las compras públicas y de los principios fundamentales de no-discriminación, equidad procesal y transparencia. La no-discriminación, implica la utilización de instrumentos que garanticen la transparencia, la publicidad de las 
disposiciones aplicables, la divulgación de los procedimientos y las prácticas relativas a la contratación pública. ${ }^{3}$

En la misma línea, los países que integran las Américas, crearon en el año 2004 la Red Interamericana de Compras Gubernamentales (RICG), como mecanismo de cooperación técnica regional, que es apoyado institucional y financieramente por la Organización de Estados Americanos (OEA), el Banco Interamericano de Desarrollo (BID) y el Centro Internacional de Investigaciones para el Desarrollo (IDRC), con la intención de aumentar la transparencia, favorecer la implementación de las tecnologías de la información, intercambiar experiencias para fortalecer prácticas en compras gubernamentales y transmitir a los ciudadanos una imagen de credibilidad de las instituciones en las actividades derivadas de las compras estatales. ${ }^{4}$

En el año 2011 se aprobó y publicó la Ley Modelo de la CNUDMI sobre la Contratación Pública de la Comisión de Naciones Unidas para el Derecho Mercantil Internacional (UNCITRAL), que determina las directrices en las compras públicas para promover la competencia, la eficiencia y la economía, así como la transparencia, la rectitud, la integridad, la confianza y la equidad en el proceso de adjudicación. El texto de la ley armoniza con disposiciones internacionales de contratación estatal, el ACP, las directivas de la Unión Europea y las normas del Banco Mundial, entre otras. ${ }^{5}$

Se caracterizan entre las disposiciones de la Ley UNCITRAL, la licitación como medio predilecto para la selección; la opción de reconsideración y apelación; el uso de las tecnologías; la subasta inversa electrónica; la promulgación de un código de conducta para el personal de compras públicas; y las particularidades del proveedor o contratista para participar, tales como, fiabilidad, idoneidad y experiencia. En su conjunto la norma propende por la objetividad en la selección al estimular la participación en igualdad de condiciones. $^{6}$

Como resultado de arduas negociaciones, el Comité de Contratación Pública de la OMC adoptó el 30 de marzo de 2012 el protocolo que modificó el ACP de 1994, el cual, 
una vez aceptado por los dos tercios de sus integrantes, formó parte de la agenda de la IX Cumbre Ministerial de la OMC en Balil, Indonesia en diciembre de 2013 y entró en vigor el 6 de abril de $2014 .^{7}$

El segundo ACP, mantiene los principios fundamentales y la apertura de los mercados de contratación pública entre sus partes, e incorpora, entre las disposiciones destacadas, la prevención de prácticas corruptas en los sistemas de contratación; el uso de herramientas electrónicas, al fortalecer el empleo de las TICs con la subasta en la era electrónica de las compras gubernamentales; y la promoción de la buena gobernanza, con el objetivo de garantizar actuaciones transparentes y brindar seguridad a las transacciones efectuadas por la red. Adicionalmente el ACP promueve las buenas prácticas en todo el mundo. ${ }^{8}$

Panamá, Argentina, Chile y Colombia son tan solo observadores del ACP, sin manifestar voluntad de adherirse, condición que les permite participar en deliberaciones sin asumir obligaciones. Colombia fue aceptada como observador por el Comité de Contratación Pública el 27 de febrero de $1996 .^{9}$

El Sistema Económico Latinoamericano y del Caribe (SELA, 2014) señaló que en América Latina y el Caribe la mayoría de países han adoptado sistemas electrónicos para acceder al mercado público; facilitado el comercio electrónico; visualizado su plan anual de compras en páginas electrónicas, lo cual permite garantizar su publicidad y seguimiento por las personas; para favorecer la participación de las pymes; y han organizado una autoridad específica para dirigir las políticas en compras gubernamentales.

El mismo análisis de las compras públicas, determinó que las pymes representan en América Latina y el Caribe importancia en el empleo regional y en la producción, por lo cual se debe garantizar en la política pública mecanismos eficaces para su inserción en las compras públicas, que involucren la transparencia en el manejo de los recursos públicos. 
En la actualidad las Mipymes de Latinoamérica se han convertido en el eje principal del desarrollo económico de muchos países, en especial de los más empobrecidos, quedando demostrado que no sólo las empresas grandes son capaces de generar crecimiento económico y empleo. Es así que a partir del crecimiento y desarrollo de la Mipymes, se ha podido combatir uno de los principales problemas que aqueja a la región, el desempleo.

Según datos de la Comisión Económica para América Latina y el Caribe (CEPAL), la presencia de las Mipymes en la estructura económica de la región es relevante, al representar un importante porcentaje de variables como la producción, el empleo y el número de empresas. (Regalado, 2007, pp. 38 - 39)

La contratación pública en la Unión Europea (UE) representó (Comisión de las Comunidades Europeas, 2008) para el año 20061.8 billones de euros, equivalentes al $16 \%$ del Producto Interno Bruto comunitario, con problemas en el acceso a las pyme, en los que prevalecieron el desconocimiento de procedimiento de licitaciones, el coste de la preparación de ofertas y la excesiva garantía financiera exigida, lo cual generó la implementación de estrategias tendientes a potenciar la participación de las pyme en los contratos gubernamentales.

La Convención Interamericana contra la Corrupción (CIACC), adoptada en 1996 en Venezuela, determinó la necesidad de cooperación entre los Estados para combatir la corrupción y tipificó entre los delitos el soborno transnacional y el enriquecimiento ilícito. Colombia firmó como Estado parte el 29 de marzo de 1996. ${ }^{10}$

El Preámbulo de la CIACC claramente determina que "la corrupción socava la legitimidad de las instituciones públicas, atenta contra la sociedad, el orden moral y la justicia, así como contra el desarrollo integral de los pueblos" y como propósito señala en su artículo II "promover y fortalecer (...) los mecanismos necesarios para prevenir, sancionar y erradicar la corrupción". ${ }^{11}$

Igualmente, la Convención de las Naciones Unidas contra la Corrupción (CNUCC), adoptada mediante Resolución 58/4 de la Asamblea General de octubre 31 de 2003, 
ratificada en México en el mismo año, que entró en vigor el 14 de diciembre de 2005, reconoce que "la corrupción ha dejado de ser un problema local para convertirse en un fenómeno transnacional que afecta a todas las sociedades y economías, lo que hace esencial la cooperación internacional para prevenirla y luchar contra ella." (ONU, 2004)

El artículo 9 de la Convención determina, con respecto a la contratación pública y la gestión en la hacienda pública, que:

1. Cada Estado Parte, de conformidad con los principios fundamentales de su ordenamiento jurídico, adoptará las medidas necesarias para establecer sistemas apropiados de contratación pública, basados en la transparencia, la competencia y criterios objetivos de adopción de decisiones, que sean eficaces, entre otras cosas, para prevenir la corrupción. Esos sistemas, en cuya aplicación se podrán tener en cuenta valores mínimos apropiados, deberán abordar, entre otras cosas:

a) La difusión pública de información relativa a procedimientos de contratación pública y contratos, incluida información sobre licitaciones e información pertinente u oportuna sobre la adjudicación de contratos, a fin de que los licitadores potenciales dispongan de tiempo suficiente para preparar y presentar sus ofertas;

b) La formulación previa de las condiciones de participación, incluidos criterios de selección y adjudicación y reglas de licitación, así como su publicación;

c) La aplicación de criterios objetivos y predeterminados para la adopción de decisiones sobre contratación pública a fin de facilitar la ulterior verificación de la aplicación correcta de las reglas o procedimientos;

d) Un mecanismo eficaz de examen interno, incluido un sistema eficaz de apelación, para garantizar recursos y soluciones legales en el caso de que no se respeten las reglas o los procedimientos establecidos conforme al presente párrafo;

e) Cuando proceda, la adopción de medidas para reglamentar las cuestiones relativas al personal encargado de la contratación pública, en particular declaraciones de interés respecto de determinadas contrataciones públicas, procedimientos de preselección y requisitos de capacitación. (ONU, 2004, pp. $12-13)$ 
En consecuencia, los Estados parte implementarán medidas para garantizar en la contratación pública la transparencia, la publicidad de los procesos realizados, las condiciones para participar y los criterios de selección, con el propósito de prevenir la corrupción.

En el año 2007 la OEA y la OCDE, con el fin de reforzar la aplicación y cumplimiento de la CIACC y CNUCC, firmaron un marco de cooperación por iniciativas anticorrupción, en el Programa Anticorrupción de la OCDE para América Latina, con objetivos comunes en la modernización del Estado, prevención y represión de la corrupción. México, Argentina, Chile, Brasil y Colombia forman parte de la Convención para combatir el Cohecho de Servidores Públicos extranjeros en Transacciones Comerciales Internacionales de la OCDE. Colombia se adhirió a la Convención el 19 de enero de $2013 .{ }^{12}$

En los anteriores escenarios resulta importante la vinculación de la sociedad civil y las empresas, con el propósito de que contribuyan en la lucha contra las prácticas corruptas, el fortalecimiento de la competitividad y la generación de códigos de buena conducta.

La OCDE señala como la violación más grave a la competitividad, los acuerdos de las empresas para no competir entre sí, por cuanto afectan directamente al consumidor al aumentar los precios, al restringir la oferta y al manipular las licitaciones mediante ofertas colusorias. Igualmente, señala que los cárteles conformados para tal propósito resultan difíciles de detectar, puesto que comprometen a muchas empresas. ${ }^{13}$

En la clasificación en la facilidad para hacer negocios Doing Business 2014, Colombia se ubica en el puesto 43 , pese a la promoción de disposiciones que protegen a los inversionistas, facilitan el comercio transfronterizo y mejoran la competitividad. (Banco Mundial, 2014) 
El desarrollo de la investigación, permitirá desde la I tesis de Trento (Ajani, Anderson, Arroyo \& Pasa, 2009), la comparación jurídica en el contexto de prácticas internacionales, con el propósito de adquirir un mejor conocimiento de la gestión pública contractual que contribuya a verificar el modelo aplicable en el ordenamiento colombiano.

En lo referente a la II tesis de Trento (Ajani et al., 2009), permitirá la comparación de los diversos fenómenos jurídicos y sociales acaecidos en la gestión contractual nacional, con el mismo criterio de validación de las ciencias históricas, desde un planteamiento cronológico y sincrónico.

En lo relativo a la III tesis de Trento (Ajani et al., 2009), se contemplará desde la comparación, los resultados útiles que se evidencian en otras latitudes, con respecto a la situación particular colombiana.

La comparación de los modelos utilizados en la actividad contractual gubernamental en el contexto internacional, permitirá identificar la congruencia del ordenamiento interno con los tratados o convenios suscritos por Colombia.

En consecuencia, el objetivo general del presente trabajo radica en establecer las regulaciones normativas del principio de publicidad en la actividad contractual del Estado, que fortalecen la transparencia, mediante una aproximación a las prácticas de los actores que realmente inciden en su concreción, con la finalidad de contribuir desde la academia en la gestión pública contractual.

Para tal propósito, el desarrollo del trabajo desde los objetivos específicos (i) analizó la evolución normativa de un marco de publicidad en los contratos celebrados por los entes públicos; (ii) determinó el alcance del principio de transparencia en el Estatuto de Contratación y su modificación; (iii) verificó la incorporación de medidas tendientes a lograr una mayor publicidad en busca de la transparencia en la actividad contractual del Estado; (iv) cuestionó los instrumentos adoptados por Colombia para luchar contra la 
corrupción; (v) determinó el impacto económico de la corrupción en la contratación pública; y finalmente, (vi) identificó prácticas de los actores en la actividad contractual que afectan la transparencia.

El problema jurídico desarrollado en esta tesis, plantea como discusión teórica ¿las regulaciones normativas adoptadas en materia de publicidad garantizan la transparencia en las prácticas contractuales del Estado?. La respuesta a la problemática permitirá formular, a partir de la realidad y su cuestionamiento, las conclusiones tendientes a fortalecer la gestión pública contractual.

La hipótesis de esta tesis radica en demostrar que el legislativo y el ejecutivo han avanzado y adoptado en materia de publicidad en la actividad contractual del Estado un marco jurídico que busca garantizar la transparencia, sin embargo, algunas prácticas de los actores inciden en su materialización. En consecuencia el trabajo identificará, a partir del marco normativo y la realidad en los procesos, las prácticas en la gestión contractual pública.

La metodología exploratoria, permitirá la aproximación a prácticas o hechos poco conocidos en la actividad contractual pública, con la intención de identificar las más relevantes, mediante estrategias que permitan determinar constantes a través de la técnica de recopilación analítica y critica de normatividad, revisión de referentes doctrinales y jurisprudenciales; estudio de recomendaciones por evaluaciones y estadísticas de organismos internacionales; y observación; con la finalidad de contemplar, estudiar y familiarizarse con el panorama de las compras gubernamentales en el contexto legal, el impacto de las reformas normativas y la realidad en la actividad contractual del Estado Colombiano.

Las investigaciones Cross-Culturales son ejemplos de estudios comparados.

El Eurobarómetro constituye un tipo de estos estudios, que se realiza en países de la Unión Europea. El Internacional Survey Program (ISSP) que es más amplio incluyendo países como Chile, Filipinas, Bangladesh, entre otros - también aparece como un modelo consistente y exitoso de encuesta transnacional. 
Los estudios comparados entre naciones están adquiriendo importancia a partir de la globalización del mundo económico y de los gobiernos transnacionales regionales (la Comunidad Europea y el Mercosur son claros ejemplos de ello). (Orler, 2010, p.218)

El marco teórico estructurado para el desarrollo del objetivo general así como específicos de la presente tesis, determinó categorías conceptuales, que permitieron abordar la problemática propuesta a través de niveles articulados y relacionados concatenadamente, que dieron la posibilidad de generar una perspectiva diferente al panorama de las compras públicas, con la intención de formular unas conclusiones en la gestión pública contractual.

Las categorías se agruparon temáticamente en dos partes. La primera, a partir de una investigación documental y crítica analizó la evolución del contrato de la administración, con la recopilación de los antecedentes de un marco de publicidad en los contratos suscritos con el Estado, desde el punto de vista legal y reglamentario; para continuar con la adopción del Estatuto General de Contratación de la Administración Pública, con el propósito de estructurar las regulaciones normativas y reglamentarias específicamente relacionadas con los postulados de publicidad y transparencia en la gestión contractual, a partir de una política pública general de contratación y la renovación de la administración pública; y finalizar en forma coherente con la recopilación y análisis crítico de las modificaciones al principio de transparencia a partir del año 2007 que incorporaron en la legislación interna medidas para prevenir y sancionar actos corruptos, derivadas de la misma constitución política y de compromisos con organismos internacionales.

Publicidad constituye, sin duda alguna, uno de los principios cardinales que deben presidir el ejercicio de la función administrativa tal como expresamente lo contempla el artículo 209 de la Constitución. Con razón se ha dicho que es de la esencia de las instituciones democráticas el carácter público de las actuaciones de la administración, al punto que sólo excepcionalmente resulta admisible una conducta diferente. 
En materia de contratación estatal, dicho principio garantiza tanto la igualdad de oportunidades para todos los proponentes, como el adecuado control del proceso de selección, además de hacer insospechable el proceder de los servidores públicos que han intervenido en su desarrollo. (Gaceta del Congreso de Colombia No. 75, 1992, p.18)

SÁNCHEZ MORÓN y GARCÍA TORRES señalan que en los procedimientos de adjudicación o licitaciones, así como en las propias adjudicaciones, la publicidad es formal, esto es, trata de garantizar jurídicamente la cognoscibilidad a los interesados mediante la predeterminada constancia documental de aquello que se hace público echando sobre el interesado la carga del efectivo conocimiento. (Expósito, 2005, p.589)

En forma correlativa, la temática correspondiente a la actividad contractual pública desarrollada en la segunda parte, inició con caracterizar el principio de transparencia como un paradigma, desde el texto primigenio de la Ley 80 de 1993, con el propósito de observar los niveles de publicidad, y determinar la transparencia en los procesos, con respecto al fenómeno de corrupción en el ámbito municipal, departamental y nacional que se presentaban hasta el año 2006, por algunas prácticas atribuidas a los actores del proceso; a continuación la categoría conceptual caracterizó, con fundamento en las situaciones detectadas, el fortalecimiento del principio de transparencia a partir del año 2007, para la cual recopiló la normatividad y trabajos de organismos internacionales a junio de 2015, fecha de terminación de la investigación, con el propósito de verificar las medidas incorporadas y los resultados de corrupción, con la finalidad de cotejarlos con respecto al periodo anterior; para continuar con una aproximación a las prácticas de los actores en la actividad contractual del Estado, que inciden en la transparencia de la gestión; lo cual permitió formular mecanismos para fortalecer las políticas públicas y la incidencia de las buenas prácticas en la gestión contractual.

La transparencia como principio rector abarca, respecto del actuar administrativo, el cumplimiento irrenunciable de los principios de legalidad, moralidad, publicidad, participación real y efectiva, competencia, razonabilidad, responsabilidad y control. (Dromi, 2008, p.70)

El procedimiento administrativo de contratación también se rige por el principio de la transparencia, el que permite ver con claridad y diafanidad el actuar de los 
órganos administrativos en la disposición y uso que se da a los fondos públicos destinados a la contratación administrativa. (Dromi, 2008, p.159)

Garantizar plenamente la transparencia de la contratación administrativa como medio para lograr la objetividad de la actividad administrativa. (García - Fernández, 2006, p.716)

Principio de transparencia que, a su turno, debe orientar la actividad contractual de las Entidades Estatales, al tiempo que constituye un presupuesto de la legalidad de la contratación pública, desde su misma génesis o formación. (Consejo de Estado, 16.450)

Todas las categorías conceptuales planteadas y desarrolladas en el marco teórico, se complementaron de manera precisa y específica con aportes jurisprudenciales y de doctrinantes nacionales y foráneos que puntualmente enriquecieron el objetivo general y objetivos específicos del trabajo, lo cual conllevó un riguroso análisis y selección de los fragmentos incorporados de manera coherente y lógica en las diferentes partes de la investigación.

Las categorías desarrolladas permitieron estructurar el estado presente y actual del conocimiento, para orientar la realización del estudio a partir de la comprensión de la normatividad nacional, de referentes internacionales y de la aproximación a prácticas reales de algunos actores en la actividad contractual del Estado, con la finalidad de ampliar el horizonte con las conclusiones.

El estudio pretende demostrar, hasta que punto el desarrollo y evolución normativa del marco de publicidad en la actividad contractual del Estado garantizan la transparencia en la gestión pública, con respecto a las prácticas que inciden en su materialización.

La caracterización de las prácticas encuentra sustento en las palabras de Soriano (2005) al señalar que " La gran aportación de Durkheim fue la de ver la importancia del hecho social como centro de la investigación social y que un hecho social se explicaba a través de otro hecho social" (p.93) 
Por ser el derecho un fenómeno social, la ciencia del derecho forma parte del grupo de ciencias que estudian la sociedad desde distintos puntos de vista (...) dado que la sociedad es una realidad totalmente distinta de la naturaleza. Por naturaleza entendemos un orden o sistema de elementos relacionados los unos con los otros por un principio particular: el de causalidad. Toda ley natural hace aplicación de este principio (...) Sólo entonces estaremos en condiciones de oponer las ciencias sociales a las ciencias de la naturaleza y ver en la sociedad un orden o un sistema diferente del de la naturaleza. (Kelsen, 2010, p.20)

En la investigación las constantes se identificaran a partir de conductas individuales, que inciden en la sociedad, para lograr aproximarse al problema planteado en la investigación.

El método pretendido está sacado de la realidad social y dotado de reglas prácticas empíricas. Efectivamente, Comte había dado ya un vuelco a la investigación social con su método positivo, pero seguía siendo éste un punto de vista del observador externo, del teórico de la investigación, si bien cercano a los hechos. Durkheim no sólo dirá que hay que partir de los hechos sociales, sino que además éstos deben ser tratados como cosas para poder construir una ciencia de la sociedad. (Soriano, 2015, p.92)

La identificación de prácticas individuales y sociales, es determinante para contextualizar el fenómeno de la corrupción y el impacto que genera su concreción.

La realidad social, y no solamente las normas jurídicas (que integran esa realidad por la doble condición ser/deber ser del Derecho) constituye la materia prima de la que debe valerse todo operador del Derecho, puesto que el análisis dogmático resulta insuficiente para describir y comprender el fenómeno de la corrupción, toda vez que el contenido material de las normas no puede explicar la realidad subyacente que, en esta temática -como en tantas otras-, suele no corresponderse con las prescripciones el ordenamiento jurídico, pues en eso consiste precisamente la corrupción, responsable en gran medida de nuestras actuales miserias.

Gran parte de las construcciones conceptuales modernas sobre la corrupción giran en torno a esa brecha entre legalidad o sistema normativo positivo y prácticas sociales, o bien, entre sistema mítico y código práctico, o entre lo escrito y lo no escrito, o entre legalidad y cultura, o entre una dimensión simbólica y una dimensión estratégica; todo lo cual determina la necesidad de situar la observación en el contexto de creación y de aplicación de las normas, excediendo el análisis meramente normativo, porque el Derecho, en definitiva, es realidad, acontecer, 
parte de todo ese conglomerado de productos sociales que situamos en la praxis (Arias, 2010, pp.381 - 382)

Las conductas caracterizadas como hechos de corrupción, han sido generalmente subsumidas en la tipología penal existente, abordando la problemática desde su faz represiva, al igual que la mayoría de los preceptos de la Convención Interamericana Contra la Corrupción.

Con relación a los aspectos organizacionales de la función administrativa, se han creado órganos con competencia específica en la materia, para la investigación de los actos de corrupción, sumados a los ya existentes que controlaron tradicionalmente la función administrativa. También se han anunciado sistemáticas acciones de gobierno para el logro de la misma finalidad y sin embargo -como he señalado en otra oportunidad-, nada de ello fue suficiente para conjurar ese flagelo y los resultados están a la vista: leyes sancionadas bajo sospecha de sobornos, venta ilegítima de armas, contratos fraudulentos, y un estado de corrupción generalizada que aún no ha cesado. Por su parte, el Poder Judicial, sospechado de falta de independencia con relación al Poder político y de no satisfacer las necesidades de los ciudadanos, tampoco ha podido brindar una respuesta efectiva, cuando no ha incurrido también en hechos de corrupción.

El fracaso de la normativa penalizadora -señala Botassino hace más que ratificar una realidad sobradamente conocida: el Derecho, por sí solo, no es capaz de variar la conducta de los gobernantes. (Arias, 2010, pp.384 - 387)

Por tanto el objeto de estudio, pretende aproximarse a esas prácticas individuales y sociales como incidencia en la materialización del postulado de transparencia en la actividad contractual del Estado a partir de un análisis normativo, crítico y fáctico.

Las modificaciones en las disposiciones, buscaron el orden en la actividad contractual pública, a través de la incorporación de principios, normas, instrumentos y procedimientos, para asegurar la eficacia en la gestión pública y disciplinar con cierto rigor a los sujetos que participan en las diferentes etapas del proceso.

Desde el punto de vista del derecho estático, la Primera Parte, a partir de un análisis crítico identificó que previo a la incorporación de instrumentos legales de publicidad en la gestión contractual, se pasó de un periodo de ausencia de normatividad específica 
en los contratos de la administración, que configuraba un manejo de poder en el ordenador del gasto; a una reglamentación excesiva.

Igualmente, se determina en forma cuantitativa el costo de la corrupción y su equivalencia en el Presupuesto General de la Nación, con observancia del impacto que genera en el mismo.

Desde el punto de vista del derecho dinámico, contempla la relación de los mecanismos dispuestos para lograr la publicidad, la transparencia, la diafanidad, la pulcritud del proceso y mitigar los actos de corrupción, con respecto a la aproximación de prácticas de los actores que inciden materialmente en la transparencia.

Por último, con fundamento en la Primera y Segunda Parte que desarrollan el objetivo general como específicos de esta investigación, se formulan las conclusiones que permiten una aproximación a resolver el problema jurídico planteado. 
Primera Parte: Evolución del Contrato en la Administración Pública 


\section{Capítulo 1.}

\section{Antecedentes en los Contratos de la Administración}

En una primera época la actividad contractual del Estado colombiano se enmarcó en la ausencia de normas específicas a los contratos de la administración, periodo en el cual las relaciones contractuales se adelantaban conforme a las disposiciones civiles y comerciales, es decir, con observancia de las reglas entre particulares y que regían en el derecho privado, en consecuencia, el representante del ente estatal, de acuerdo al marco legal aplicable, gozaba de plena libertad para suscribir contratos que comprometían recursos públicos sin procedimiento alguno para escoger al contratista.

En esa primera etapa las controversias contractuales del Estado fueron asignadas a la jurisdicción ordinaria, por cuanto no existía jurisdicción contenciosa administrativa, la que solo vino a proveerse en el ordenamiento constitucional de 1886 y a establecerse definitivamente por el legislador con la expedición de la Ley 130 de 1913, primer código contencioso, de aplicación a partir de diciembre de 1914, cuando por el acto legislativo de dicho año (sep. 10) se establece el Consejo de Estado, suprimido en 1905 (A.L. No. 10), como cabeza de la jurisdicción y se entra a proveer los tribunales seccionales, e igualmente por considerarse la actividad contractual de la administración como una actividad de gestión privada del Estado. Recuérdese la clasificación en actos de poder y actos de gestión en boga en esa época y durante muchos años, que se extendió hasta gran parte de la primera mitad del siglo XX.

En consecuencia, en el precitado ordenamiento constitucional de 1886 se contempló expresamente en el artículo 151-3 - art. 148-3 de la reforma constitucional de 1936, compilado como art. 146 - que la Corte Suprema conocería de las contenciones en que tuviera parte la Nación, contenciones entre las cuales se encontraban las contractuales. (González, 2004, p.16)

Regulación que Santofimio (2000) resaltó al citar: "Precisamente Carlos H. Pareja, en 1937, al describir las características jurídicas del contrato celebrado por las entidades públicas en todos sus niveles, se quejaba de su absoluta sujeción al derecho privado y a la jurisdicción ordinaria" (p.49). 
El Consejo de Estado (M.P. Giraldo Gómez, Expediente 12.723, 2000) al resolver un asunto en particular, precisó como antecedentes en los contratos de la administración y relacionados con la facultad de declarar la caducidad los siguientes:

La potestad de la Administración para declarar la caducidad del contrato tiene su fuente en la ley. En la historia legislativa (...) se encuentran como antecedentes los que siguen:

la ley 53 del 27 de noviembre de 1909 (arts. 4 y 5º); que la consagró por primera vez;

ley 110 del 23 de noviembre de 1912, Código Fiscal de la Unión (Art. 41), que desarrolló la figura y dispuso las causales de caducidad. (Expediente 12.723)

La facultad otorgada al Estado para declarar unilateralmente la caducidad por primera vez en el año 1909, concibe desde ese entonces la necesidad de contar con disposiciones que diferenciaran los contratos públicos de los privados, puesto que el fin de los primeros era satisfacer el interés general al que debía someterse la administración pública.

Regulaciones como las contenidas en la ley 53 de 1909, que dio la posibilidad a los ministros de declarar la caducidad de los contratos de obras públicas, en caso de incumplimiento de los contratistas; muestra que la facultad o poder del Estado para ejercer una potestad unilateral, no podía seguir manejándose por el derecho privado. La ley 110 de 1912 estableció la obligatoriedad de pactar caducidad en los contratos de obras públicas y de prestación de servicios; estipulaciones que no pueden ser objeto de los contratos particulares, por el estricto plano de igualdad que debe existir entre las partes del mismo. (Güechá, 2007, p.116)

El segundo Código Contencioso Administrativo, expedido con ocasión de la Ley 167 de 1941, señaló disposiciones específicas a las relaciones de los contratos celebrados por entes públicos. En el Capítulo XXI denominó la relación como Contratos de la Administración. En el artículo 242 determinó un trámite en virtud de la cuantía que implicaba una vez impartida la aprobación ejecutiva la remisión al Consejo de Estado para que decidiera si estaban o no ajustados a las autorizaciones, remisión que de acuerdo al artículo 243 debía realizarse también en los contratos sobre exploraciones, 
explotaciones de petróleos y de metales preciosos. Sin la revisión del Consejo de Estado no podía ejecutarse ningún contrato.

Como lo señala Matallana (2009) el "concepto de contrato administrativo colombiano fue importado de Francia, en donde se parte de seguir un procedimiento rígido de contratación" (p.117).

La ley en cita también indicó, a partir del artículo 254, en qué contratos debía incluirse la facultad de declaratoria administrativa de Caducidad y como causales la muerte del contratista y la incapacidad financiera por declaratoria de quiebra o concurso de acreedores, situaciones que configuraban o daban lugar a una terminación del contrato. Igualmente reguló la forma de decretar la caducidad, sus efectos y las prestaciones a que se obligaban las partes.

El artículo 73 de la misma ley determinaba como no acusables ante la jurisdicción contencioso administrativo las resoluciones de las autoridades originadas en un contrato, lo que evidencia para la época un régimen dominado por el derecho privado.

En esta materia, en Colombia podemos decir que hemos tenido tres etapas, en cuanto al juez o jurisdicción encargada de conocer de las contenciones en que tenga parte una entidad estatal en relación con un contrato y en cuanto a la clasificación y denominación de los diferentes vínculos celebrados por entes públicos, una primera que va desde los comienzos de la republica hasta el mes de julio de 1965, cuando entra a regir el decreto ley 528 de 1964, lapso durante el cual las contenciones contractuales fueron de la competencia de la jurisdicción ordinaria, concretamente de los jueces civiles, Corte Suprema de Justicia, sala civil o sala de negocios generales; salas civiles de los tribunales Superiores de Distrito Judicial, y jueces civiles del circuito, etapa en la cual, por lo demás, no tenía objeto alguno clasificar los contratos. (González, 2004, p.15)

En virtud del posterior desarrollo legislativo la Sala Plena de lo Contencioso Administrativo (M.P. Giraldo Gómez, Expediente 12.723, 2000) con respecto a las atribuciones para resolver conflictos originados en las relaciones contractuales de entes públicos señaló: 
La jurisdicción competente para conocer de las controversias contractuales era ya la de lo Contencioso Administrativa por virtud de lo dispuesto en el decreto ley 528 de 1964. Este decreto (arts. 6, 20, 30 y 32) introdujo la dualidad de jurisdicciones para conocer de las controversias derivadas de la actividad de la Administración, pues la jurisdicción Ordinaria conocía de asuntos eminentemente privados contenciosos de las entidades públicas y la jurisdicción de lo Contencioso Administrativa estaba instituida para "definir los negocios originados en las decisiones de la Administración" y las controversias relativas a contratos administrativos, entre otros. (Expediente 12.723)

Se advierte de la anterior jurisprudencia, que la segunda etapa normativa en Colombia, contempló la dualidad de jurisdicciones, por asuntos privados contenciosos de las entidades públicas y por negocios originados en la decisión de la administración, distinción que permitía determinar la jurisdicción competente en resolver los litigios presentados.

Que comenzó el $1^{\circ}$ de agosto de 1965, cuando entran a regir los arts. 30 y siguientes del decreto ley 528 de 1964, que trasladaron las controversias originadas en los denominados contratos administrativos de la jurisdicción ordinaria civil a la jurisdicción contenciosa del Consejo de Estado y tribunales administrativos. (González, 2004, p.15)

En vigencia del Decreto 528 de 1964 el desarrollo jurisprudencial del Consejo de Estado entre 1970 y 1975, en lo referente a la competencia y al carácter del contrato indicó que:

El juez administrativo, a través del análisis y estudio del correspondiente contrato, determinaba si era competente para su juzgamiento en la medida en que se encontraran argumentos para sustentar su naturaleza de contrato administrativo; de lo contrario, la competencia correspondía a la justicia ordinaria. (Santofimio, 2000, p.37)

El contrato administrativo es el acto creador de obligaciones en el cual el ente estatal hace prevalecer su poder público, es decir, utiliza ventajas o privilegios que usualmente no se presentan en los contratos privados. (Santofimio, 2000, p.38) 
En agosto 18 de 1975 se expide el Decreto Ley 1670 que aplicaba, por así disponerlo su artículo $1^{\circ}$ a los contratos celebrados por la Nación, Ministerios o Departamentos Administrativos, los Establecimientos Públicos, las Empresas Industriales y Comerciales del Estado y las Sociedades de Economía Mixta en las que la Nación poseía más del noventa por ciento. (90\%)

La aplicación limitada que se advierte de la norma, implicaba la coexistencia de disposiciones de orden territorial que regulaban la materia de manera especifica y particular lo que generaba dispersión normativa.

El artículo 47 incluyó la caducidad entre las cláusulas que forzosamente debían contener los contratos y el artículo 53 presumió su pacto por ausencia de disposición contractual que expresamente la consignare, norma fundamental para estructurar el contenido vigente en la actualidad de las potestades excepcionales.

Dentro de las causales de caducidad, además de las contempladas en la Ley 167 de 1941, la norma citada determinó la disolución de la sociedad del contratista y el incumplimiento de las obligaciones a cargo del contratista, disposición desafortunada por pretender enlistar causales diferentes en su naturaleza y esencia.

También determinó en el artículo 17 los requisitos previos a la celebración de contratos escritos, a través de licitación pública o privada. En el numeral $3^{\circ}$ del artículo 22 señaló como regla para la licitación pública, que se publicarían, con anticipación no inferior a diez (10) días de la fecha de apertura de la licitación, por lo menos dos avisos en diferentes fechas en dos o más periódicos de amplia circulación, con observancia del lugar en el que sé cumpliría la prestación, antecedente importante para estructurar la publicidad de los actos previos a la celebración del contrato en la administración.

El numeral d) del artículo 17 en cita, determinó un trámite complejo en el que intervenían varias autoridades, que comprendía el concepto del Consejo de Ministros, 
la aprobación del Presidente de la Republica y conservó la revisión del Consejo de Estado.

El artículo 31 determinó taxativamente en qué casos se podía prescindir de la licitación pública o privada, con el propósito de adelantar una contratación directa, por situaciones que contemplaban, entre otros, la naturaleza del contrato, la cuantía y la ausencia de suscripción del contrato por el favorecido, que permitía adjudicar al calificado en segundo lugar.

El título XI reguló en qué casos procedía la liquidación de los contratos, la autoridad competente, la forma de realizarla, su contenido y prescribió que los contratos de suministro y de obras debían liquidarse.

El Decreto Ley 150 de enero 27 de 1976 derogó la anterior disposición y reguló en términos similares el campo de aplicación; la responsabilidad; las cláusulas obligatorias; las clases de licitación pública y privada; y lo referente a la liquidación.

Aunque el interés por producir un estatuto que recogiera toda la legislación sobre contratos existía desde varios años atrás, no se había logrado nada, salvo la expedición de innumerables normas dispersas, en ocasiones contradictorias, con grandes vacíos. (Lamprea, 1979, p.19)

En las reglas para la licitación pública mantuvo en el numeral $3^{\circ}$ del artículo 22 la exigencia de publicar por lo menos dos avisos en diferentes fechas en dos o más periódicos de amplia circulación, con observancia del lugar en que sé cumpliría la prestación y señaló que la inserción en los diarios se efectuaría dentro de los veinte (20) días anteriores a la apertura de la licitación, cambio que en su época buscaba una mayor difusión a los posibles interesados.

A la licitación procede la formulación del pliego del pliego de cargos, y a ella siguen en rigurosa sucesión, primeramente la adjudicación y después el otorgamiento del contrato. Pero como la licitación es un acto reglado, o satisfactorio o no satisfactorio de una propuesta depende de que se ajuste o no al pliego de cargos. 
De otra manera las autoridades recobrarían una discrecionalidad que, por los peligros que ofrece, la ley ha querido evitar. (Rodríguez, 1977, p.40)

Igualmente, mantiene el trámite complejo previo a la suscripción de los contratos que comprendía el concepto del Consejo de Ministros, la aprobación del Presidente de la Republica y la revisión del Consejo de Estado, el cual era excesivo y configuraba coadministración del juez competente, que para ese entonces en virtud de la Ley 528 de 1964 estaba instituida para definir las controversias relativas a los contratos de la administración, cuya eventual demanda podría comprometer situaciones acaecidas en los actos previos a la suscripción del contrato.

Al elaborar una teoría del contrato administrativo hemos aplicado, en cuanto ha sido posible, los principios generales que gobiernan la institución contractual, los cuales se han sistematizado y ajustado para presentar un análisis aproximado del fenómeno de derecho público que es el contrato de la administración en Colombia; la cuestión, sin embargo, es muy compleja; los criterios de clasificación para distinguir los contratos administrativos de los de derecho privado de la administración no son constantes; se dice, por ejemplo, que la cláusula exorbitante es un criterio fundamental, pero ni siquiera en este aspecto tan importante existe unanimidad en el país; generalmente se le identifica con la cláusula de caducidad cuya inclusión es obligatoria en determinados casos; pero la sola inclusión de la cláusula de caducidad no confiere carácter de administrativo a un contrato. (Lamprea, 1979, p.31)

El Decreto Ley 1670 de 1975 y el Decreto Ley 150 de 1976, en sus 204 artículos, pasaron de un periodo de ausencia de normas específicas, a uno con rigor y exceso de reglas en los contratos celebrados por ciertos entes estatales.

Posteriormente, el Decreto Ley 222 de febrero 02 de 1983 derogó las normas contrarias y reguló el campo de aplicación en términos similares a las precedentes disposiciones, con extensión, conforme al último inciso del artículo $1^{\circ}$ de las reglas referidas a tipos de contratos, su clasificación, efectos, responsabilidades y terminación, a los departamentos y municipios; al extender los efectos de la norma únicamente a esos tópicos, los entes territoriales regulaban otros aspectos, que por consiguiente diferían de un ente al otro. 
Un total de 301 artículos conformaron el decreto aludido, que regularon en exceso y de manera minuciosa muchos detalles como los referidos a la urna en que se depositarían las propuestas. El análisis normativo evidencia, el paso de la omisión absoluta de reglas previas a la celebración del contrato, a un compendio meticuloso en asuntos que no revestían tal carácter.

El decreto mantuvo en los literales e), f) y g) del artículo 25 los requisitos del concepto del Consejo de Ministros, la firma del Presidente de la Republica y la revisión del Consejo de Estado en los contratos administrativos y de derecho privado de la administración y señaló en los artículos 50, 252 y 255 a partir de qué cuantía se exigía su revisión. En el artículo 51 determinó que con la ejecutoria de la providencia del Consejo de Estado se entendían perfeccionados los contratos. De la norma se advierte la complejidad de trámites previos a perfeccionar el contrato.

El Capítulo $3^{\circ}$ contempló requisitos adicionales para ciertos entes, verbigracia se exigía a los Establecimientos Públicos la aprobación del Ministro o Jefe de Departamento Administrativo y la cuantía de revisión por parte del Consejo de Estado.

El cúmulo de disposiciones allí contenidas y la precaria celeridad que permitía fueron profusamente criticadas ya que se encontraban inútiles y excesivos controles establecidos para determinados contratos, los que, en no pocas ocasiones generaron parálisis administrativa con la consecuente desatención del servicio público y de las necesidades básicas de la comunidad. (Rico, 2009, p.09)

El decreto condicionó la adjudicación del contrato al señalar en su artículo 35 como efectos que "cuando la ley subordine el perfeccionamiento de un contrato a la aprobación o revisión de un organismo o autoridad superior, la adjudicación no producirá otro efecto que el de obligar a la entidad contratante y al adjudicatario a cumplir los demás requisitos establecidos para el caso."

En lo referente a la cláusula de caducidad, incluyó en el artículo 49 como causales, además de lo dispuesto en las anteriores normas, la incapacidad física permanente del 
contratista y la interdicción judicial, causales que circunscriben nuevamente diversidad en cuanto a su naturaleza y esencia.

Determinó como clases de licitación la pública o privada y señaló en el numeral $3^{\circ}$ del artículo 30 como regla en la primera de las citadas, la publicación dentro de los veinte (20) días calendario anteriores a la apertura de la licitación de por lo menos dos avisos en uno o más periódicos de amplia circulación nacional. Se advierte de la norma, que buscaba publicidad en el territorio nacional.

Otras características (...) se encuentran en los procesos de selección de contratistas y el excesivo reglamentarismo de normas, que permitieron la proliferación de la corrupción administrativa por cuanto no sujetaban a la administración a seleccionar sus contratistas con criterios objetivos. Pero si lo anterior era criticable, lo eran más los excesivos controles que se imponían para seleccionar al contratista, traducidos en instancias de autorizaciones que pasaban desde el Consejo de Estado hasta el Consejo de Ministros, lo cual dilataba la iniciación del contrato con evidentes consecuencias presupuéstales, dado que la iniciación del contrato dependía de los ajustes al valor del contrato por aumento de costos. (Matallana, 2009, p.118)

Como se advierte de las disposiciones y doctrinantes en estudio, los excesos reglamentarios, la complejidad de trámites y los controles inútiles, constituían espacios para la corrupción y retardos o parálisis de la administración con efectos económicos antes de iniciar el contrato, que implicaban el ajuste del valor.

Con respecto a la tipología en las relaciones contractuales de los entes a los cuales se aplicaba, el decreto en cita, en el Título III los clasificó en Contratos Administrativos y de Derecho Privado de la Administración, carácter que definía el juez del contrato ante eventuales controversias. El artículo 16 enlistó los contratos administrativos y señaló que se consideraban de derecho privado de la administración los demás, a menos que la ley especial dispusiera lo contrario. 
El artículo 17 contempló la dualidad de jurisdicciones y determinó que de acuerdo con la calificación del contrato, en administrativo o de derecho privado, el conocimiento se atribuía al Contencioso Administrativo o a la Justicia ordinaria.

También fue motivo de creciente critica la clasificación dual de los contratos públicos hecha por el Decreto 222 de 1983, la cual dificultaba en grado sumo no solo la determinación exacta de su naturaleza, sino también y consecuentemente, la fijación de las reglas de interpretación y la jurisdicción ante la cual se ventilarían las diferencias que pudieran surgir en la ejecución, interpretación o terminación de dichas relaciones jurídicas. (Rico, 2009, p.10)

Igualmente, determinó que el registro de proponentes a cargo de los entes estatales daba la posibilidad a quienes se encontraban inscritos de presentar propuesta en los procesos que adelantaba la respectiva entidad. Los requisitos para inscribirse variaban por cuanto el mismo estatuto determinaba en su artículo 44 que se efectuaría en el formulario que preparaba y distribuía la entidad contratante.

Del análisis normativo se advierte, que a la fecha se encuentran vigentes del Decreto 222 de 1983 los artículos 108 a 113 del Capítulo 3ํㅡ, relacionados con la ocupación y adquisición de inmuebles e imposición de servidumbres.

El Tercer Código Contencioso Administrativo, adoptado por el Decreto 01 de 1984, determinó, en su texto original, al contencioso como el juez natural en las acciones relativas a controversias derivadas de un contrato de derecho privado de la administración con cláusula de caducidad o de un contrato administrativo.

El propósito del capítulo es determinar, conforme al objetivo general así como específicos de la investigación, los antecedentes normativos en los contratos de la administración que dieron tránsito de la aplicación de un marco de derecho ordinario a uno de derecho público en consideración a los fines del contrato, periodo en el cual las normas adoptadas buscaron brindar publicidad a algunos procesos de contratación adelantados por la administración, como un primer intento de resolver el problema planteado en la tesis. 


\section{Capítulo 2.}

\section{El Contrato de la Administración Pública en la Ley 80 de 1993}

Como resultado de la Asamblea Nacional Constituyente, en 1991 se adopta la nueva Constitución Política de Colombia, que incorpora el modelo de Estado Social de Derecho y reconoce principios y garantías fundadas en el respeto, la dignidad, la participación, la legalidad, la pluralidad, la igualdad y la seguridad jurídica.

Por más que las constituciones formales intenten recoger completamente la materia constitucional, lo cierto es que en todos los países, aún en los que han optado por textos constitucionales muy extensos, se hace preciso el desarrollo legislativo de numerosas materias propiamente políticas. La Constitución formal se limita a recoger las líneas fundamentales, los grandes principios, y luego el legislador mayoritario, de acuerdo con sus propias concepciones políticas (en realidad su "programa de gobierno"), debe regular con más detalle esas materias e instituciones, eso sí, sin apartarse del marco constitucional. (García, 2002, p.227)

En el modelo acogido, la Corte Constitucional (M.P. Calle Correa, Sentencia C-713, 2009) señaló que la actividad contractual y el fin de la contratación pública en el Estado Social de Derecho se materializan:

Para la jurisprudencia constitucional la actividad contractual en el Estado social de derecho es una modalidad de gestión pública, regida por los principios de igualdad, moralidad, eficacia, celeridad, economía, imparcialidad y publicidad previstos en los artículos 209 y 123 de la Constitución Política como parámetros específicos del cumplimiento de la función administrativa (...)

El fin de la contratación pública en el Estado Social de Derecho está directamente asociado al cumplimiento del interés general, puesto que el contrato público es uno de aquellos "instrumentos jurídicos de los que se vale el Estado para cumplir sus finalidades, hacer efectivos los deberes públicos y prestar los servicios a su cargo, con la colaboración de los particulares a quienes corresponde ejecutar, a nombre de la administración, las tareas acordadas. De hecho, la contratación del Estado es una de las formas de actuación pública de mayor utilización, pues muchos sostienen que el contrato estatal surge con la propia consolidación del Estado moderno, pues cuando éste asume la responsabilidad de prestar los servicios y adelantar funciones para la defensa de los derechos de los administrados $y$, por ese hecho, aumenta la complejidad de las tareas a su cargo, necesita del apoyo, la intervención y la experiencia que aportan los particulares. (C-713, 2009) 
En el artículo 150 de la Carta Magna se facultó al Congreso de la República para expedir el estatuto general de contratación de la administración pública y en especial de la administración nacional, reconocimiento que deja en libertad de configuración al legislador para el logro de los objetivos constitucionales del Estado Social de Derecho, como se determinó por la Corte Constitucional (M.P. Calle Correa, Sentencia C- 713 de 2009) al precisar:

De la Constitución no es posible inferir la obligación para el legislador de incorporar en un solo cuerpo normativo toda la legislación existente en materia contractual, pues si ésta hubiera sido la voluntad del constituyente, en el artículo 150 Fundamental se habría autorizado al Congreso de la República para expedir un estatuto único de contratación para el Estado y no un estatuto general como prevé la disposición constitucional (...)

En éste orden de ideas, es innegable el carácter instrumental que ostenta el contrato estatal, puesto que no es un fin en sí mismo sino un medio para la consecución de los altos objetivos del Estado (...)

En virtud de la potestad de configuración que se comenta el Congreso tiene libertad para regular los aspectos más significativos de la contratación pública como son los referentes a las cláusulas excepcionales, la clasificación de los contratos estatales, los deberes y derechos de las partes contratantes, la competencia y capacidad para contratar, principios fundamentales, nulidades, control de la gestión contractual, responsabilidad contractual, liquidación de los contratos y solución de las controversias contractuales, entre otros, todo dentro de los límites de razonabilidad y proporcionalidad y con arreglo a los parámetros constitucionales. (C-713, 2009)

Con respecto a la facultad constitucional Matallana (2009) señaló: "Finalmente, un aspecto que obligó a revisar el régimen de contratación anterior fue la entrada en vigencia de un nuevo orden constitucional y su exigencia al legislador de expedir un nuevo régimen de contratación estatal" (p.118).

En virtud de la competencia superior, el Congreso expidió la Ley 80 en octubre 28 de 1993, por la cual adoptó el Estatuto General de Contratación de la Administración 
Pública, régimen que determinó la tipología de Contrato Estatal y definió el juez del contrato en el contencioso.

Finalmente, llegamos a la tercera etapa en la cual nos encontramos, en la cual aparece la figura del CONTRATO ESTATAL - noción que reemplaza la dualidad contrato administrativo - contrato de derecho privado de la administración (...) Perdió la jurisdicción ordinaria, entonces, la competencia para conocer de aquellas contenciones relacionadas con los contratos de derecho privado de la administración. (González, 2004, pp.17 - 18)

El artículo 75 de la Ley 80 de 1993, determinó a la jurisdicción contenciosa administrativa como "el juez competente para conocer de las controversias derivadas de los contratos estatales", disposición que finalizó con la dualidad jurisdiccional que hasta esa época prevaleció.

La Ley 80 de 1993, contiene la regulación, o, por lo menos, fue su intención, de un régimen único de contratación, acabando la dispersión de normas. En consecuencia, quedo por fuera la facultad consagrada en el artículo $5^{\circ}$ de la Ley 19 de 1982, derogada expresamente por el artículo 81 del nuevo Estatuto Contractual, la Ley 80 de 1993, que permitía a los departamentos y municipios, en desarrollo de su autonomía, que dispusieran en sus estatutos fiscales, respetando los elementos esenciales que señala la ley, sobre la formación y adjudicación de los contratos que celebren, conforme a sus intereses y a las necesidades del servicio. (Palacio, 2003, p.26)

El nuevo régimen definió en él capítulo II como principios específicos de la contratación estatal, la Transparencia, la Economía y la Responsabilidad. En desarrollo del Principio de Transparencia determinó que la escogencia del contratista se efectuaría a través de licitación o concurso público, salvo los casos de contratación directa que fijó taxativamente. Postulado que pretendía garantizar la posibilidad de conocer las actuaciones tendientes a la escogencia del contratista y la publicidad de las mismas.

Por lo que se refiere al principio de transparencia (...) garantiza la imparcialidad y por consiguiente la escogencia objetiva de contratistas. Implica que dicha escogencia se efectúe siempre a través de licitación o concurso, salvo las excepciones previstas en la misma norma, y que en los procesos contractuales los interesados tengan oportunidad de conocer y controvertir los informes, conceptos y 
decisiones que se rindan o adopten, para lo cual se deben establecer etapas que permitan el conocimiento de dichas actuaciones y otorguen la posibilidad de expresar observaciones. Las actuaciones de las autoridades deben ser públicas y los expedientes que las contengan igualmente deben estar abiertos al público. (C400, 1999)

Describe Palacio (2003) que la licitación "ha sido la regla general para la contratación en Colombia, que somete la misma a reglas drásticas, cuyo respeto garantiza el control y la moralidad de la administración, lo cual está acorde con el régimen democrático del Estado" (p.53).

En las etapas de preparación, celebración y ejecución de los contratos estatales, los servidores públicos deben buscar el cumplimiento de los fines estatales definidos en el artículo $2^{\circ}$ del Estatuto Superior y el contratista es un colaborador para alcanzar tales propósitos.

Los valores de la axiología administrativa se plasman en los contratos administrativos, en tanto tienen por causa, motivo o razón determinante la satisfacción de un fin público, y su objeto es siempre aquel en el que la realización y prestación sirven a los fines excluyentes y concurrentes del Estado. En la hipermodernidad se avanza en la nota de colaboración del contratista en el logro del bien común. Los contratos públicos, además de herramienta del programa general de gobierno, edifican un nuevo modelo de Estado, en tanto instrumento de gestión pública.

Por la incidencia del interés público en el contrato administrativo la Administración y el contratista no pueden ser considerados simples partes que negocian, son también "colaboradores que se encuentran", aún cuando persigan propósitos distintos. El contratista, como colaborador de la Administración, participa de los esfuerzos comunes. Adhiere al fin de bien común que encierra el contrato, superando el antiguo "principio de desconfianza". Para la Administración su contratista es un colaborador voluntario, aunque no desinteresado, con un interés incluso pecuniario, pero no necesariamente opuesto o antagónico al del Estado. (Dromi, 2008, pp.24 - 25)

Para la convocatoria a licitación o concurso público, se determinó en el numeral $3^{\circ}$ del artículo 30 de la Ley 80 de 1993, que se publicarían dentro de los diez (10) a veinte (20) días calendario anteriores a su apertura hasta tres avisos en diarios de amplia 
circulación en el territorio de jurisdicción de la respectiva entidad. Igualmente, señaló que "En defecto de dichos medios de comunicación, en los pequeños poblados (...) se leerán por bando y se fijarán por avisos en los principales lugares públicos por el término de siete (7) días calendario, entre los cuales deberán incluir uno de los días de mercado", disposición que buscaba la publicidad de los procedimientos tendientes a la escogencia del contratista.

El estatuto adoptado en 1993 creó el Registro Único de Proponentes y determinó que la Cámara de Comercio sería la encargada del mismo, así como de certificar las personas que se encontraban inscritas, clasificadas y calificadas para contratar con el Estado; en consecuencia, con dicha certificación el interesado podía participar en todo proceso de selección que adelantaran entidades públicas en todos los niveles, órdenes y sectores. Con la implementación del registro único desaparece la limitación que se advirtió en el capítulo anterior, para participar en un proceso de selección por no encontrarse inscrito en el registro de proveedores del ente a cargo de la contratación.

Uno de los principios que rige la contratación estatal es el principio de concurrencia, el cual se manifiesta en el derecho que les asiste a todas las personas de participar en un plano de igualdad en las licitaciones o concursos públicos, a fin de realizar una oferta de negocios jurídicos a la administración, para que, luego de agotado un proceso de selección, esta adjudique el contrato a aquella propuesta que resulte más favorable para el interés público. (Cuello, 2009, p.91)

Mediante el Decreto 855 de 1994 se reglamentó la Contratación Directa y se determinó en el artículo $3^{\circ}$ que en la causal de Menor Cuantía se requería obtener previamente por lo menos dos (2) ofertas. Si el valor era igual o superior a Cien Salarios Mínimo Legales Vigentes (100 SMLV) y al mismo tiempo superaba el cincuenta por ciento (50\%) de la Menor Cuantía de la respectiva entidad, además debía invitarse públicamente a presentar propuesta a través de un aviso publicado en un lugar visible de la misma entidad por un término no menor de dos días. Se advierte de la norma, el manejo y control de la entidad para acreditar su cumplimiento. 
La anterior disposición fue modificada por los artículos $1^{\circ}$ y $2^{\circ}$ del Decreto 2170 de 2002, que determinaron que los proyectos de pliegos y pliegos definitivos en licitación o concurso público y en los casos señalados en contratación directa, se publicarían en la página web de la entidad que adelantaría el proceso, norma afortunada para garantizar los principios de publicidad y transparencia en la escogencia del contratista, así como la utilización de medios electrónicos en la contratación pública. De la norma en cuestión se evidencia que la publicación se realiza en página web de la entidad que adelanta el proceso, es decir, que nuevamente el ente contratante es el responsable de acreditar su cumplimiento.

La anterior disposición fue derogada por el Decreto 2434 de 2006, que determinó en los artículos $1^{\circ}$ y $2^{\circ}$ que la publicación de los proyectos de pliegos y pliegos definitivos se efectuaría en el Portal Único de Contratación, instrumento de publicación independiente del ente contratante y de los interesados, con acceso desde una conexión a Internet, lo cual garantizaba una mayor transparencia y publicidad en la actividad contractual adelantada por las entidades sometidas al Estatuto General de Contratación de la Administración Pública, al obligar a publicar la información contractual en el referido medio electrónico, norma que en su oportunidad entró en vigencia en forma progresiva.

Una de las críticas a las disposiciones que precedieron la Ley 80 de 1993 radicó en el exceso o dispersión de normas, suceso desafortunado que se repitió y configuró con más de 40 decretos que reglamentaron el Estatuto General de Contratación de la Administración Pública en un lapso de 15 años como se advirtió de la recopilación reglamentaria para el desarrollo de la investigación.

Además de lo anterior, se advierte que la Ley 80 de 1993, denominado estatuto único, mantiene varios regímenes especiales, lo que constituye dispersión normativa.

Ese anhelo de establecer un régimen contractual único para superar la regulación insular, dispersa, contradictoria entre las diferentes entidades, no se logró y sólo parcialmente alcanzó este propósito. En este sentido se concluye que habrá 
entidades a las que se les aplica el régimen de la Ley 80 de 1993 y otras que no, y más aún, habrá algunas a las que se les aplica un doble régimen contractual, el de la Ley 80 , cuando celebren un contrato que no sea de servicios públicos domiciliarios, y la contratación privada, cuando el objeto que desarrolle corresponda a estos servicios. (Palacio, 2003, p.28)

En consecuencia, desde un análisis legal en el contrato estatal se identifican dos categorías, que involucran recursos públicos, cuya definición de controversias corresponde al contencioso administrativo:

Tipos de contratos. A juicio de la Sala es preciso reconocer que en las diversas regulaciones normativas sobre contratación de la administración pública es posible identificar dos grandes categorías de actos contractuales: 1. Contratos estatales, propiamente dichos, que son aquellos que celebran las entidades públicas a que se refiere la ley 80/93, y por ende se regulan íntegramente por el régimen establecido en esta ley. Por regla general, adquieren este carácter en razón del ente público contratante, es decir, se definen desde el punto de vista orgánico. Las controversias que se deriven de este tipo de contratos y de los procesos de ejecución o cumplimiento serán de conocimiento de la jurisdicción contenciosa administrativa. 2. Contratos especiales sujetos a un régimen legal propio. Por regla general, el juez a quien compete conocer de sus controversias es el juez administrativo, en razón de que su celebración y ejecución constituye una actividad reglada, es decir, es el ejercicio pleno de una función administrativa, de conformidad con el artículo 82 del Código Contencioso Administrativo. De lo anterior, es jurídicamente viable considerar que la categoría "contratos estatales" no puede quedar exclusivamente referida a los actos contractuales que celebren las entidades del Estado relacionadas con la ley 80/93, sino que habría que reconocer que desde el punto de vista material y técnico formal, constituye una acertada categoría jurídica que tiene la virtud de englobar todos los contratos que celebren las entidades públicas del Estado, ya sea que se regulen por el estatuto general de contratación administrativa o que estén sujetos a regímenes especiales. De tal manera, es dable hablar genéricamente de dos tipos de contrato: a) contratos estatales regidos por la ley 80/93; b) contratos estatales especiales. Auto de agosto 20/98, expediente 14202. Consejero. Dr. Juan de Dios Montes Hernández. (Cuello, 2009, p.4)

La necesidad de estructurar las bases de una política pública general para la contratación de los entes públicos se recomendó por el Consejo Nacional de Política Económica y Social, en los documentos CONPES 3186, 3248 y 3249, en los cuales diagnosticó en la actividad contractual del Estado, entre otras: ausencia de transparencia en los procedimientos adelantados; que la corrupción ha generado sobre 
costos en los bienes o servicios contratados, que la proliferación de decretos reglamentarios sin unidad de criterio afecta el entorno de la contratación pública, con una normatividad compleja que hace primar la incoherencia; y que las barreras de la información son un aliado a la ineficiencia en la gestión pública y la corrupción. En consecuencia, recomendaron preparar la modificación del Estatuto General de Contratación, así como definir políticas que estimularán la concurrencia y la posibilidad de una nueva cultura gerencial de administración de lo público con eficiencia, honestidad, austeridad y la creación de un sistema electrónico de contratación que contribuya a contrarrestar los actos de corrupción.

Con el alcance que ha dado la Corporación al principio de libre concurrencia, encuentra la Sala que no vulnera el artículo 333 de la Carta, porque lo que garantiza la Constitución es la igualdad de oportunidades de acceso a la participación en un proceso de selección contractual (art. $13 \mathrm{CP}$ ), y la oposición y competencia en el mismo, de quienes tengan la real posibilidad de ofrecer lo que demanda la administración, en el marco de las prerrogativas de la libertad de empresa. (C-713)

El CONPES 3186, Una Política de Estado para la Eficiencia y la Transparencia en la Contratación Pública, con fundamento en el Informe de Evaluación de Adquisiciones (CPAR) realizado a la regulación colombiana por el Banco Mundial en el año 2000 con participación de funcionarios y contratistas del Estado, formuló, las bases de una política pública general para la contratación que propiciara la eficiencia, la transparencia y considerara el impacto socio - económico de la misma.

El CPAR analizó la dispersión normativa y señaló, que la Ley 80 de 1993 con la premisa de ser el Estatuto Único de Contratación terminó por convertirse no en la regla sino en una excepción más, por la existencia de normas que regulan regímenes especiales y que los numerosos decretos reglamentarios de la ley en comento desarticulan su vocación unificadora. Encontró también ineficaz el registro único de proponente; deficiencias en la etapa de planeación de los contratos públicos; falta de articulación en las normas presupuéstales y contractuales; y puntualizó que los vacíos 
que se presentaban en las normas favorecen la venalidad y la corrupción. (CONPES $3186,2002)$

EI CONPES también, atribuyó la corrupción y falta de transparencia, a la baja calidad de las auditorias y a la ausencia de controles a las fuentes de la corrupción. Por tanto la necesidad de una política pública con dos objetivos primordiales, la eficiencia en la utilización de los recursos públicos y la transparencia para evitar corrupción. (CONPES $3186,2002)$

El CONPES 3248, Renovación de la Administración Pública, señaló que en el 49.7\% de las licitaciones se realizan pagos adicionales para asegurar la adjudicación y cerca del $50 \%$ de montos de condenas contra la nación provienen de relaciones contractuales defectuosas. El diagnóstico atribuye los factores a la inexistencia de una política pública que fije objetivos de satisfacer necesidades a través de la contratación; a la proliferación de regímenes especiales; a la dispersión reglamentaria; a la excesiva discrecionalidad de los entes para diseñar procesos contractuales; a la ausencia de sistemas de información; y a la falta de información pública en materia contractual. Por consiguiente, formuló, la necesidad de diseñar un nuevo marco normativo que elimine las posibilidades de direccionamiento en la selección de los proponentes, pero que a la vez aumente la eficiencia administrativa y la reducción de costos de transacción para las entidades públicas, en busca de una mayor publicidad en los procesos con la implementación de un sistema electrónico de contratación.

El Consejo Nacional de Política Económica y Social CONPES, en el documento 3249 de 2003 - Política de Contratación Pública para un Estado Gerencial, señaló como prioridad la transparencia en las actuaciones del Estado, la pulcritud en la escogencia de sus contratistas y condiciones de contratación más favorables para el Estado, con el propósito de mitigar los actos de corrupción y buscar la eficiencia en la asignación de los recursos públicos. Por consiguiente identificó desde el punto de vista institucional, la necesidad de implementar una política de renovación de la administración pública: 
Cuyo objetivo es el replanteamiento del aparato estatal dirigido a la materialización de una precisa concepción del Estado: el Estado Comunitario que se realiza a través de un Estado participativo (que estimule la participación y que tenga en cuenta las demandas ciudadanas), un Estado gerencial (que administre lo público con eficiencia, honestidad, austeridad y por resultados) y un Estado descentralizado (que tenga en cuenta las necesidades locales sin perjuicio del interés nacional y de la solidaridad regional. (CONPES, 3249, 2003, p.4)

En su diagnóstico el CONPES 3249 determinó, según encuesta realizada por el Banco Mundial, que en Colombia el valor promedio de soborno en un contrato público es del $19 \%$, impacto que afecta la transparencia y genera sobre-costos en la contratación. Lo que evidencia la falta de probidad de algunos servidores y oferentes que buscan ser adjudicatarios al brindar dádivas o porcentajes para resultar favorecidos, puesto que la corrupción no es solo un flagelo que se enmarque en lo público, sino también, en los intereses de personas o emporios de derecho privado que son generosas en tales ofrecimientos y a la vez reclaman reglas justas y de transparencia.

Las encuestas del BM y de Confecámaras muestran que en estas condiciones de contratación pueden gestarse procesos de "selección adversa" porque vastos sectores empresariales se han marginado de las oportunidades de trabajar con el Estado debido a la poca transparencia en los procesos licitatorios, con lo cual se ha restringido la competencia por los negocios estatales. Al indagar sobre los criterios de rechazo básicos para su no participación, cerca de la mitad de los empresarios encuestados consideraron, en orden de importancia: i) la competencia injusta, ii) la complejidad en el proceso licitatorio y iii) tener contactos personales dentro de la entidad contratante, aspectos que ratifican la existencia de un creciente nivel de desconfianza respecto a la capacidad del Gobierno para establecer reglas claras de participación para las entidades y los oferentes, y corregir las deficiencias existentes en la mayoría de los procesos de contratación del Estado. (CONPES, 3249, 2003, pp. 6 - 7)

Con la finalidad de fortalecer los instrumentos para luchar contra los actos de corrupción, el legislador mediante la Ley 412 de 1997 aprobó la Convención Interamericana Contra la Corrupción (CICC) suscrita en Caracas en marzo 29 de 1996 y la Corte Constitucional en Sentencia C-397 de 1998 declaró su constitucionalidad, lo cual permitió en el ordenamiento colombiano fortalecer los compromisos de la lucha 
contra la corrupción y la participación de la sociedad civil en la prevención, al respecto precisó el órgano de cierre Constitucional:

El contenido del artículo VI de la Convención que se revisa, compromete a los países signatarios a incluir en sus legislaciones internas, como delitos, varias conductas que por sus características constituyen actos de corrupción, conductas cuyos elementos esenciales constitutivos, per-se, son violatorios de principios fundamentales del Estado social de derecho, e impiden la realización de los fines esenciales del mismo, entre ellos la prevalencia del interés general y la promoción de la prosperidad de la sociedad. Ello hace que su inclusión como tipos penales en nuestra legislación interna, encuentre fundamento (...) mientras el legislador colombiano procede expresamente a tipificar el soborno transnacional como delito, el Estado podrá legítimamente y sin contrariar el ordenamientos superior, brindar asistencia y cooperación a los demás países miembros de conformidad con las disposiciones de nuestro ordenamiento interno (...)

Para la Corte es claro que la creciente globalización e internacionalización de la economía, la cada vez más necesaria disolución de las fronteras para el ejercicio del comercio entre países dada la apertura de los mercados, y el avance acelerado de la ciencia y la tecnología, aspectos que modificaron sustancial y estructuralmente el manejo de las relaciones y del comercio internacional, ocasiona, como consecuencia inevitable, la paralela transnacionalización de los delitos, especialmente de aquellos en los que subyacen conductas de corrupción, lo que implica que los sistemas legales de los países que aspiren a colaborarse recíprocamente para la prevención y sanción de los mismos, deban adaptarse y modificarse para el efecto. (C-397, 1998)

En el modelo de Estado adoptado, corresponde al mismo mitigar y prevenir los actos de corrupción, así como fortalecer el principio de transparencia y el control en el manejo de recursos públicos, en tal sentido, la Corte en Sentencia C-172 de 2006 precisó:

La obligación del Estado colombiano de implementar instrumentos jurídicos de diversa naturaleza, dirigidos a la prevención de la corrupción es consecuencia natural de los postulados constitucionales que propugnan por la transparencia en el ejercicio de la función pública como condición necesaria para el debido funcionamiento del sistema democrático. Así, la justificación misma del Estado Social de Derecho pasa, entre otros aspectos, por la sujeción de la actuación de sus autoridades a los principios de legalidad, objetividad y debida utilización de los recursos públicos. Por lo tanto, las actuaciones venales, la concesión de ventajas indebidas dentro de los procedimientos estatales, el ocultamiento de información a 
los ciudadanos y la restricción de los legítimos espacios de participación ciudadana en la administración, entre otras conductas, son incompatibles con las previsiones constitucionales que propugnan por la protección del interés general como base misma del Estado. Así, ante la grave afectación que los actos de corrupción irrogan a bienes jurídicos intrínsecamente valiosos en tanto están estrechamente relacionados con principios y valores constitucionales, toda actuación que tenga por objeto la prevención del fenómeno es, no sólo acorde a la Carta, sino también una vía adecuada y necesaria para la realización de las finalidades del aparato estatal.

No puede perderse de vista, adicionalmente, los elementos innovadores que contiene la Convención, relacionados con la extensión de la prevención de los actos de corrupción al ámbito privado y el reforzamiento de la participación ciudadana en esta labor. Acerca del primer aspecto, es evidente que el instrumento internacional reconoce, a juicio de la Corte de forma acertada, que el tratamiento de la corrupción resulta incompleto si no incorpora medidas adecuadas y suficientes que garanticen las buenas prácticas de las empresas que interactúan permanentemente en la actividad estatal. La experiencia demuestra que distintos escenarios de la función pública, como es el caso de la contratación, resultan con frecuencia relacionados con actos de corrupción ocasionados, la mayoría de las veces, por la ausencia de controles efectivos a la actuación de los particulares que concurren en tales procesos. (C-172, 2006)

La Sentencia C 172 de marzo 08 de 2006 declara exequible la Ley 970 de 2005, por medio de la cual se aprobó la Convención de las Naciones Unidas Contra la Corrupción (CNUCC), adoptada por la Asamblea General de las Naciones Unidas el 31 de octubre de 2003 en Nueva York.

El propósito del capítulo es determinar, conforme al objetivo general así como específicos de la investigación, el alcance del principio de transparencia en la Ley 80 de 1993 y la reglamentación, al identificar las diferentes etapas en materia de publicidad hasta el año 2006, periodo en el cual las normas adoptadas buscaron brindar mayor publicidad en los procesos de selección de contratistas por la administración y establecer las bases de una política pública en contratación, así como la incorporación de instrumentos internacionales, como un segundo intento de resolver el problema planteado en la tesis. 


\section{Capítulo 3.}

\section{Las Reformas en el Marco de Probidad a partir de la Ley 1150 de 2007}

La Ley 80 de 1993 es modificada por la Ley 1150 de 2007, que introduce medidas para la eficiencia y la transparencia en la contratación con recursos públicos. Para dicho propósito determinó en el artículo $2^{\circ}$ y en virtud del Principio de Transparencia como Modalidades de Selección: la Licitación Pública, el Concurso de Méritos, la Selección Abreviada y la Contratación Directa. A su vez, el artículo 94 de la Ley 1474 de 2011 adiciona la Modalidad de Selección de Mínima Cuantía, que también se había previsto en reglamentaciones anteriores, que incluso se demandaron por incompetencia del ejecutivo en su regulación.

La exposición de motivos del proyecto de ley de origen gubernamental que dio paso a la Ley 1150 de 2007 señala claramente su intención (...) de introducir medidas para mejorar la eficiencia y transparencia en la gestión contractual y contrarrestar la corrupción.

(...) reglas que pretenden satisfacer los principios que orientan la función administrativa, previstos en el artículo 209 de la Carta (igualdad, moralidad, eficacia, economía, celeridad, imparcialidad y publicidad), y que imponen a las entidades estatales asegurar el cumplimiento de tales principios en los contratos que celebran. $(\mathrm{C}-713,2009)$

El desarrollo del principio de transparencia guarda coherencia con los postulados de la función administrativa determinados en el artículo 209 de la Constitución Política.

Principio de la Transparencia. Mediante este principio se ataca la corrupción; con él se busca garantizar la moralidad en la contratación, la imparcialidad de la administración en la escogencia del contratista al exigir que se haga de acuerdo con unas reglas precisas, claras, completas y objetivas. En este principio se conjugan también el de igualdad, el de publicidad, y de libre concurrencia 0 competencia, que sirven de base a la forma más clara de selección del contratista, que es la licitación, pero que deben estar presentes en los otros mecanismos de selección del contratista cualquiera que sea la forma acogida (...)

La publicidad de las actuaciones contractuales garantiza la transparencia que permite a la comunidad ejercer control sobre ella, ya sea por conducto de las 
asociaciones cívicas comunitarias, de profesionales, benéficas o de utilidad común, quienes podrán denunciar ante las autoridades competentes las actuaciones, hechos u omisiones (...) que constituyan contravenciones o faltas en materia de contratación estatal. (Palacio, 2003, p.53)

El principio de transparencia como mandato imperativo a la administración, debe observarse en la actividad contractual del Estado y en el resultado de la gestión pública contractual.

Transparencia quiere decir claridad, diafanidad, nitidez, pureza y translucidez. Significa que algo debe ser visible, que puede verse, para evitar la oscuridad, la opacidad, lo turbio y lo nebuloso. Así, la actuación administrativa, específicamente la relación contractual, debe ser perspicua, tersa y cristalina.

Se trata, sin duda, de un postulado que pretende combatir la corrupción en la contratación estatal, que en sus grandes líneas desarrolla también los principios constitucionales de igualdad, moralidad, eficiencia, imparcialidad y publicidad aplicados a la función administrativa. (Cuello, 2009, pp.91 - 92)

La estructura adoptada en la Ley 1150 de 2007 de las Modalidades de Selección, considera el objeto o tipo de contrato a realizar, mantiene el carácter de regla general en la licitación pública y a las demás atribuye un carácter excepcional al configurarse una causal determinada, clasificación que resulta acorde, por cuanto no es lo mismo comprar elementos de papelería, que adelantar una consultoría, que realizar una interventoría o construir una obra civil; en consecuencia, la selección corresponde al tipo de contrato a celebrar que por su naturaleza o esencia difieren.

A ese respecto es claro que las experiencias exitosas a nivel internacional demuestran que el criterio de distinción que debe gobernar el esquema contractual eficiente, es el modular de las modalidades de selección en razón a las características del objeto. (Gaceta Congreso No. 458 de 2005, p.8)

Conforme a desarrollos jurisprudenciales, el legislador determinó en el artículo 13 de la ley en cita, con respecto a las entidades que por disposición legal cuenten con un régimen especial, aplicarán en su actividad contractual (Gaceta Congreso No. 458, 2005) los principios de la función administrativa, de la gestión fiscal y estarán 
sometidas al régimen de inhabilidades e incompatibilidades, norma que buscaba mitigar actos de corrupción presentados en entes regulados por regímenes especiales y que afectaron los recursos públicos involucrados en la celebración de sus contratos, verbigracia, el contemplado en la Ley 100 de 1993, que permite contratar con observancia de las reglas entre particulares.

En el artículo $3^{\circ}$ de la Ley 1150 de 2007 se fortalecieron los Principios de Publicidad y Transparencia al crear el Sistema Electrónico para la Contratación Pública (SECOP) al determinar que las actuaciones derivadas de la actividad contractual podrán tener lugar por medios electrónicos, estrategia que resulta idónea para combatir la ineficiencia administrativa y la corrupción en la actividad contractual del Estado. En consecuencia y conforme a la reglamentación del Gobierno Nacional, los entes estatales comenzaron a publicar en el SECOP los procesos de contratación que pretendían adelantar.

El sistema fue administrado inicialmente por el Ministerio de las Tecnologías de la Información y las Comunicaciones, como punto único web de información de la actividad contractual de los entes estatales para toda persona interesada y la ciudadanía en general.

En concordancia, el artículo 224 del Decreto Ley 019 de 2012 modifica el numeral 3 del artículo 30 de la Ley 80 de 1993 y señala como regla en las convocatorias a licitación que se publicarán hasta 3 avisos en la página web de la entidad y en el Sistema Electrónico para la Contratación Pública, situación innecesaria, por cuanto constituye doble actuación de la administración y el espíritu de la disposición indicada es agilizar, simplificar y suprimir trámites superfluos en la administración.

Inició la reglamentación de la Ley 1150 de 2007 con el Decreto 066 de enero 08 de 2008, disposición que entró a regir ese mismo día, lo cual generó un caos en los entes estatales y principalmente en los territoriales que comenzaban con periodo constitucional de mandatarios, por cuanto el decreto no reglamentó varios aspectos y facultó a cada entidad para expedir en acto administrativo la regulación específica, 
como en el caso de la contratación inferior al diez por ciento (10\%), programas de protección, así como para adquirir bienes y servicios para la seguridad nacional, lo cual constituyó dispersión normativa por la proliferación de manuales diferentes, por lo tanto, los requisitos para participar variaban de un sujeto público a otro. Situación que fue criticada seriamente en regulaciones anteriores a 1991 y que sé auspicio con el decreto citado.

Además de lo anterior, la reglamentación en su aplicación presentaba inconsistencias y contradicciones, lo cual conllevo a que en menos de 6 meses se derogara por el Decreto 2474 de julio 07 de 2008, con excepción de su artículo 83 que expresamente derogó los decretos o disposiciones contenidas en el artículo 25 del Decreto 679 de 1994, el Decreto 855 de 1994, 1898 de 1994, 329 de 1995, 1275 de 1995, 287 de 1996, salvo sus artículos $3^{\circ}$ y $4^{\circ}, 2964$ de 1997, 1436 de 1998, 2334 de 1999, 2170 de 2002, salvo sus artículos $6^{\circ}, 9^{\circ}$ y 24, 3740 de 2004, 2503 de 2005, 219 de 2006, 959 de 2006, 2434 de 2006, 4117 de 2006, 4375 de 2006, 499 de 2007 y las demás normas que le fueren contrarias.

El Decreto 2474 de julio 07 de 2008 corrige los yerros que se presentaban y mantiene la exigencia del manual para los entes estatales, lo cual configuraba dispersión normativa, ello sumado al cúmulo de modificaciones que se presentaron a partir de la referida fecha y las nuevas reglamentaciones que se expidieron para temas específicos.

Luego de varias reformas reglamentarias, el Decreto 734 de 2012 derogó en su integridad las disposiciones vigentes de los Decretos 679 de 1994, 287 de 1996, 2170 de 2002, 1896 de 2004, 2166 de 2004, 066 de 2008, 1170 de 2008, 2474 de 2008, 3460 de 2008, 4828 de 2008, 4444 de 2008, 4533 de 2008, 127 de 2009, 490 de 2009, 931 de 2009, 2025 de 2009, 2493 de 2009, 3806 de 2009, 3576 de 2009,1039 de 2010,1430 de 2010, 1464 de 2010, 2473 de 2010,3844 de 2010, 4266 de 2010, 2516 de 2011, 3485 de 2011 así como las demás normas que le fueren contrarias, y subrogó aquellas reproducidas expresamente en el mismo decreto. 
Sumado a lo anterior, desde el primer decreto reglamentario (Decreto 066 de 2008) el ejecutivo reglamentó cinco (5) modalidades de selección, cuando la Ley 1150 de 2007 en su artículo $2^{\circ}$ solo determino cuatro (4), situación que configuraba extralimitación de funciones en la facultad reglamentaria y que fue objeto de demandas de nulidad simple, en las cuales la Sección Tercera de la Sala Plena de lo Contencioso Administrativo del Consejo de Estado concedió inicialmente la suspensión provisional y posteriormente la nulidad de las disposiciones demandadas, oportunidades en que el ejecutivo expedía un nuevo decreto en el que reproducía los apartes suspendidos.

Sobre la reproducción reglamentaria del gobierno nacional de disposiciones suspendidas, el Consejo de Estado (M.P. Gil Botero, Sentencia 36.054, 2010) señaló:

La lectura de las dos disposiciones transcritas no deja duda alguna, el ejecutivo mediante el artículo 3 del decreto 2025 de 2009 reprodujo, en su esencia, lo dispuesto por el artículo 46 del Decreto 2474 de 2008, incurriendo de esta manera en la prohibición establecida en el artículo 158 del C.C.A. Es más, el único cambio realizado se limita a eliminar las referencias que en la norma suspendida provisionalmente se hacía a los denominados manuales de funciones.

Por esta razón, la Sala declarará la nulidad del artículo 3 del decreto 2025 de 2009 con fundamento en los razonamientos expuestos respecto del artículo 46 del decreto 2474 de 2008. (Sentencia 36.054)

Las reglamentaciones del ejecutivo en lo referente al Registro Único de Proponentes, generaron caos en el sector de las obras públicas, por los constantes cambios, con modificaciones que exigieron registrarse en la Clasificación Industrial Internacional Uniforme -CIIU -, el cual limitaba a los posibles interesados a tan solo unas actividades de las que desarrollaba, en consecuencia, tal exigencia se reemplaza al año de su adopción por el Clasificador de Bienes y Servicios - CBS -, el cual permite la inscripción en las actividades que realmente puede realizar el interesado. Igualmente, se presentaron constantes cambios en la acreditación de la ' $\mathrm{k}$ ' o capacidad de contratación, en un principio se exigió la sumatoria de todos los contratos en ejecución y luego con el Decreto 1397 de 2012 solo los saldos de los contratos de obra en el año 
inmediatamente anterior, desde un análisis normativo se infiere que castigaba a los contratistas que celebraron contratos en dicho periodo o que tenían al tope su ' $k$ ' y premiaba a quienes no habían contratado en ese lapso.

Mediante la Ley 1437 de 2011 se adopta el actual Código de Procedimiento Administrativo y de lo Contencioso Administrativo, que desarrolla los postulados de la Constitución Política de 1991 y determina, conforme a los desarrollos jurisprudenciales, que conocerá de los asuntos relativos a los contratos con recursos públicos de cualquier régimen.

En el año 2011 se crea mediante el Decreto 4170 la Agencia Nacional de Contratación Pública - Colombia Compra Eficiente, con el propósito de desarrollar políticas públicas orientadas a una mayor eficiencia, transparencia y optimización en los recursos del Estado, mejores prácticas, así como el desarrollo y administración del Sistema Electrónico para la Contratación Pública. (SECOP)

Colombia Compra Eficiente se encarga de desarrollar y administrar el SECOP, en tal virtud, asumió los contratos y convenios celebrados por el Ministerio de las Tecnologías de la Información y las Comunicaciones que se encontraban vigentes.

En desarrollo de las funciones de Colombia Compra Eficiente, el Ejecutivo a través del Departamento Nacional de Planeación, expide el Decreto 1510 de julio 17 de 2013, por el cual deroga el Decreto 734 de 2012 y reglamenta, entre otras, la Ley 80 de 1993 y la Ley 1150 de 2007, bajo la denominación de sistema de compras y contratación pública. Infortunadamente, se advierte de las normas en estudio, que el gobierno continuó con la línea de efectuar modificaciones parciales como las contenidas en el Decreto 3054 de 2013 y en el Decreto 791 de 2014. Igualmente, la jurisdicción contenciosa suspendió algunas disposiciones.

La justificación para crear un Sistema Nacional de Compras Públicas está relacionada con la necesidad de impulsar una revolución ética de combate a la corrupción, para lo cual se requiere que se transparenten los procesos de 
contratación pública y que, además, se abra el sistema a la producción nacional. De esta manera se pretende mejorar la creación de puestos de trabajo y fomentar la participación efectiva de microempresas y pymes como proveedoras del sector público. (Ferraro - Stumpo, 2010, p.227)

El Decreto 1510 facultó a Colombia Compra Eficiente para regular los aspectos no contemplados en el mismo, a través de manuales y guías que han sido adoptados mediante circulares, que al contemplar la voluntad del ente obligan tal como lo hace un acto administrativo, lo cual constituye un tipo de concentración que restaría autonomía a los entes contratantes para adelantar sus procedimientos. En consecuencia, a la fecha se han expedido varias guías o manuales en temas específicos, verbigracia sobre el 'k' o capacidad de contratación, circulares que también derogan, modifican y sustituyen otras, lo cual genera una nueva forma de dispersión normativa.

Igualmente, el Decreto 1510, definió en su artículo 3ำ para efectos contractuales los acuerdos comerciales en los siguientes términos: "son tratados internacionales vigentes celebrados por el Estado colombiano, que contienen derechos y obligaciones en materia de compras públicas, en los cuales existe como mínimo el compromiso de trato nacional para: (i) los bienes y servicios de origen colombiano y (ii) los proveedores colombianos."

La dinámica internacional en los contratos en el ámbito tanto privado como público, su importancia en el crecimiento de los países y la competitividad han dado lugar a conductas o usos, sobre las cuales el Consejo de Estado (M.P. Santofimio Gamboa, radicación 50219) precisó:

Se trata de un resurgimiento de la llamada lex mercatoria o, lo que es lo mismo, un conjunto de prácticas o hábitos con relevancia jurídica aceptados en el ámbito mercantil internacional sin que medie allí regulación del Estado. Ejemplo de ello, entre otros, son los Incoterms establecidos por la Cámara de Comercio Internacional, los principios y trabajos particulares de Unidroit, Uncitral (...) conjunto de principios europeos de los contratos.

(...) referencias (...) para evidenciar cómo la regulación jurídica comercial no depende de la voluntad soberana de los Estados, pues aún existiendo un derecho 
interno que regule una situación o un tratado internacional sobre la materia, las dinámicas y necesidades cambiantes del comercio transnacional han impulsado, con fuerza jurídica aceptada, prácticas, normas, estándares o parámetros de conducta mercantil (...)

Una vez se tiene conciencia de este punto se puede afirmar que la convencionalidad en materia económica implica la aceptación de regímenes jurídicos paralelos al derecho estatal que, bajo ciertas circunstancias, tienen eficacia jurídica reconocida por los estados. (Radicación 50219)

En la misma sentencia, el máximo órgano de la Jurisdicción Contenciosa señaló, con respecto al artículo $2^{0}$ de la Ley Modelo de Contratación Pública UNCITRAL y el ordenamiento interno, que el contenido de la Ley de las Naciones Unidas comprende:

Un conjunto de definiciones relacionadas con la contratación estatal así como el documento denominado "Glosario de términos relacionados con la contratación pública utilizados en la Ley Modelo", donde se compendia un conjunto de definiciones sobre la materia contrastadas con las adoptadas por otros órganos internacionales. Es decir, se trata de la existencia de conceptos sobre la materia en el derecho internacional, de modo tal que la normativa colombiana sobre contratación pública debería ser leída e interpretada conforme a dichos derroteros $(\ldots)$

Lo anterior cobra relevancia persuasiva para la Administración Pública en los procedimientos de contratación por cuanto, por una parte, se trata de definiciones adoptadas por un órgano internacional cuya misión fundamental gravita alrededor de la unificación de regulaciones jurídicas que promuevan el comercio internacional y, por otro tanto, en razón a que algunas disposiciones de la Ley 1150 de 2007 han sido adoptadas con fundamento en la Ley Modelo citada. (Radicación 50219)

Como quiera que la reglamentación adoptada en el Decreto 1510 de 2013 determinó en su artículo $3^{\circ}$ definiciones aplicables en la actividad contractual al indicar que "Los términos no definidos en el presente decreto y utilizados frecuentemente deben entenderse de acuerdo con su significado natural y obvio" el Consejo de Estado determinó claramente en la sentencia en cita, con el propósito de brindar mayor seguridad jurídica a los actores en la contratación pública que:

No duda la Sala de la importancia que tienen estos documentos para la Administración Pública, pues las definiciones allí incluidas no atienden al sentido 
natural y obvio de las palabras sino que, por el contrario, se encuentran enfocadas hacia el sentido que deben tener dentro del argot contractual del Estado conforme al ordenamiento jurídico internacional lo que, a la postre, redunda en mayor precisión de los términos empleados y seguridad jurídica para los partícipes (...)

Los anteriores casos, ponen de presente cómo se requiere de una comprensión amplia e integral del ordenamiento jurídico positivo enriquecido por la vía de los tratados de derecho internacional debidamente incorporados o, en otros casos, del soft law donde lo que se advierten estipulaciones sobre conceptos o definiciones con relevancia en la actividad contractual del Estado (...)

Así, la convencionalidad en el derecho, y específicamente en lo relacionado con la contratación estatal, impone el respeto y el sometimiento para la Administración Pública de aquellas estipulaciones establecidas en Tratados Internacionales sobre definiciones con relevancia en el derecho contractual del Estado. Igualmente, el soft law constituye un valioso referente persuasivo que debe ser considerado de manera ponderada por la Administración ya que es reflejo de desarrollos consuetudinarios del comercio internacional que, por lo mismo, aportan seguridad jurídica y certidumbre respecto de los términos empleados en las relaciones contractuales. Finalmente, la convencionalidad se muestra en un tercer escenario desde el enfoque de los Derechos Humanos, donde se predica el respeto que debe la Administración hacia los derechos garantías allí reconocidos, lo cual repercute directamente en la interpretación de términos y cláusulas contractuales que, dado el caso, puedan contravenir el derecho convencional. (Radicación 50219)

En consecuencia, el ordenamiento interno en materia de contratación pública en su aplicación e interpretación, debe guardar armonía con las disposiciones internacionales ratificadas por Colombia, en especial en la CICC y la CNUCC, así como la lex mercatoria que con relevancia son aceptadas en las relaciones mercantiles internacionales, con el propósito de brindar las operaciones de seguridad jurídica, confianza y buena fe de los diferentes actores.

Adicionalmente, la Ley 1508 de 2012 estableció el régimen jurídico de las Asociaciones Público Privadas, reglamentada por el Decreto 1467 de 2012, modificado por los Decretos 100 de 2013 y 301, 1553 y 2043 de 2014, lo cual en su conjunto mantiene la tendencia de dispersión normativa. 
Como se advierte de la recopilación de disposiciones, más de 40 decretos reglamentarios han regulado la Ley 1150 de 2007 en apenas siete años de vigencia, situación que afecta la seguridad jurídica y el principio de transparencia como lo ha precisado el Consejo de Estado y Transparencia por Colombia, por cuanto se dieron en dicho lapso constantes derogatorias, modificaciones, suspensiones provisionales y posteriores declaratorias de nulidad decretadas por el Consejo de Estado a varias disposiciones del reglamento, así como fallos de inexequibilidad de la Corte Constitucional.

Las constantes modificaciones y derogatorias de la reglamentación a la Ley 80 de 1993 y a la Ley 1150 de 2007 en periodos tan cortos afectan la seguridad jurídica y la confianza de los actores en la contratación pública, además de constituir espacios para la proliferación de actos de corrupción, al respecto el Consejo de Estado (M.P. Andrade Rincón, radicación 35362) precisó:

No puede dejar la Sala de advertir la volatilidad normativa a la que el Ejecutivo ha sometido la actividad contractual del Estado. Sin duda, los propósitos de las reglamentaciones son los más encomiables, pero dejan entrever una débil estructuración de la política pública en materia contractual, lo cual, por contera, incrementa los riesgos de corrupción en una actividad que es particularmente sensible a este corrosivo fenómeno. En menos de 5 años las entidades públicas y los proveedores del Estado han contado con 4 actos reglamentarios que pretenden compilar la mayor parte de aspectos relacionados con la gestión contractual de la administración pública y también han visto cómo tales reglamentaciones han sido modificadas y derogadas, incrementado la inseguridad jurídica en detrimento de los intereses del conglomerado y de la satisfacción de sus necesidades. (Radicación, 35362)

Los efectos de la corrupción inciden en el orden interno y en las relaciones internacionales, como lo advierte la Corte Constitucional en Sentencia C-944 de noviembre 14 de 2012 al declarar exequible la Ley 1573 de 2012, por medio de la cual se aprobó la Convención para Combatir el Cohecho de Servidores Públicos Extranjeros en Transacciones Comerciales Internacionales, al señalar: 
Desde el punto de vista político, la corrupción reduce la confianza de los ciudadanos en el Estado de derecho, pues implica el desprecio de los intereses de los ciudadanos (...) se afecta la legitimidad de las decisiones del gobierno y del funcionamiento del Estado de derecho, generándose la apatía y el desconcierto de la comunidad $(\ldots)$

Desde el punto de vista económico, la corrupción reduce la inversión, aumenta los costos económicos, disminuye las tasas de retorno y obstaculiza el comercio internacional, aumentando los precios de los bienes y servicios y reduciendo su volumen y calidad (...) Adicionalmente, facilita la formación de monopolios de hecho, conformados por las empresas que pagan sobornos (...)

Desde el punto de vista administrativo público (...) hace que los recursos públicos se desvíen hacia los patrimonios particulares o del entorno de los funcionarios corruptos (...) Por otro lado, se merman las rentas públicas, teniendo en cuenta que el coste irregular del pago de los sobornos constituye una inversión para eludir el pago de costos como los tributos... Adicionalmente, la reducción de la inversión y del gasto público, ocasionada por la corrupción, afecta directamente el desarrollo económico a largo plazo, situación que se evidencia especialmente en los países menos desarrollados (...)

Desde el punto de vista jurídico, la corrupción afecta el correcto funcionamiento de la Administración pública, es decir, el funcionamiento del Estado de acuerdo a los principios de la función pública, en especial de la objetividad, la imparcialidad, la legalidad y la eficiencia. (C-944, 2012)

La Sentencia en cita determina, que el delito de corrupción de agente público extranjero internacional nació en foreing Corrupt Practices Act promulgada en 1977 en Estados Unidos, tipo que se incorporo en muchos países de Europa, adicionalmente la OCDE fomenta su tipificación en el mundo. Igualmente, señala las formas como se adoptó en Alemania, Francia, Austria, Rumania, Bélgica, Italia, España, México, Uruguay, Argentina, Chile y concluye que en Colombia el delito es compatible con la Constitución por ser una conducta lesiva al orden económico, que afecta la igualdad y la imparcialidad en el tráfico internacional.

En la exposición de motivos de la Ley 1474 de 2011, por la cual se incorporaron instrumentos internacionales para luchar contra la corrupción en el ámbito público y privado se puntualizó: 
La corrupción es uno de los fenómenos más lesivos para los Estados modernos, pues a través del mismo se vulneran los pilares fundamentales de la democracia y se desvían millonarios recursos en perjuicio de las personas menos favorecidas. Por esta razón, Colombia ha ratificado tratados y convenios internacionales en desarrollo de los cuales se han aprobado leyes y decretos tendientes a perseguir este flagelo (...)

Se sancionan nuevas conductas punibles cuya existencia proviene de diversas convenciones internacionales y que están consagrados en algunos países europeos, todo con la finalidad de evitar la impunidad de eventos que presentan características especiales que los diferencian de otros delitos, tales como el cohecho propio respecto de acto cumplido, el fraude de subvenciones y los acuerdos restrictivos de la competencia (...)

Se realizan una serie de modificaciones para armonizar la legislación nacional con las convenciones internacionales, mejorar la técnica legislativa de algunas disposiciones y agravar algunas penas. (Gaceta del Congreso de Colombia No. 607,2010, pp.16 - 18)

La Ley 1474 de 2011 en el Capítulo V determina los Organismos Especiales para la Lucha contra la Corrupción, en el artículo 62 crea la Comisión Nacional para la Moralización, en el artículo 65 establece que en cada departamento instalará una Comisión Regional de Moralización y en el artículo 66 crea la Comisión Nacional Ciudadana para la Lucha contra la Corrupción, con funciones especificas en las que se destacan el seguimiento y promoción de valores, para luchar contra la corrupción.

La Comisión Nacional para la Moralización, instalada en marzo 06 de 2012, se concentró en la formulación y aprobación de la Política Pública Integra Anticorrupción PPIA, en los avances del proyecto de Ventanilla Única de Denuncias, en la construcción de lineamientos para las Comisiones Regionales de Moralización y en los avances del proyecto Observatorio de Transparencia y Anticorrupción. ${ }^{14}$

Transparencia que en el modelo chileno es considerada ejemplar y les ha permitido asesorar a Singapur, Panamá, Salvador, Ecuador, Colombia, Paraguay, México, Brasil, España y Argentina. 
En julio de 2012 comenzó en Colombia la operación del Observatorio de Transparencia y Anticorrupción, con el objetivo de generar mecanismos para la toma de decisiones en la implementación de políticas públicas eficaces en la lucha contra la corrupción y la integridad. La Secretaria de Transparencia se encarga de su administración y funcionamiento desde septiembre del mismo periodo y en el año 2013 inició con la construcción de indicadores para medir los logros de la PPIA. ${ }^{15}$

La Comisión aprobó las líneas de la PPIA y posteriormente el CONPES 167 de diciembre 09 de 2013, Estrategia Nacional de la Política Pública Integral Anticorrupción, reconoce la magnitud y complejidad de corrupción presentada en Colombia y propone sugerencias en la rama ejecutiva en el ámbito nacional, en la rama judicial y en los órganos de control, sin incluir acciones específicas que sean responsabilidad de las entidades territoriales. En lo referente a la actividad contractual del Estado, determina como estrategias simplificar y agilizar el sistema de contratación, reducir la dispersión normativa y la difusión de buenas prácticas desde la Procuraduría. ${ }^{16}$

Dispersión que nuevamente intenta unificar el Gobierno Nacional con el Decreto 1082 de mayo 26 de 2015, por medio del cual se expide el Decreto Único Reglamentario del Sector Administrativo de Planeación Nacional, al compilar las normas del Decreto 1510 de 2013, Decreto 1467 de 2012 y Decreto 2043 de 2014, entre otros.

Como lo señaló Orrego (2014), "En el afán de crear una nueva institucionalidad para combatir la corrupción, algunos países han caído en la tentación de multiplicar instituciones con facultades y objetivos similares, produciendo en ciertos casos la clara ineficiencia" (p.64).

Con la implementación de las Modalidades de Selección y la utilización de medios electrónicos en la actividad contractual se busca garantizar los principios de publicidad y transparencia en la actividad contractual del Estado y la probidad en el manejo de los recursos públicos. 
En forma coherente, el capítulo determina, conforme al objetivo general y específicos de la investigación, las regulaciones legales y reglamentarias en materia de publicidad y transparencia en la actividad contractual del Estado con énfasis en las reformas adoptadas a partir del año 2007 que incorporaron instrumentos internacionales para brindar una mayor publicidad y contrarrestar el fenómeno de corrupción, como un tercer intento de responder al problema planteado en la tesis. 
Segunda Parte: La Actividad Contractual Pública en el Estado Colombiano 


\section{Capítulo 1.}

\section{El Paradigma del Principio de Transparencia en la Ley 80 de 1993}

El Estatuto General de Contratación de la Administración Pública - Ley 80 de 1993 desarrolla los postulados de la función administrativa dispuestos en el artículo 209 de la Constitución Política de 1991, de celeridad, economía, eficacia, imparcialidad, igualdad, publicidad y moralidad a los que deben sujetarse tanto las entidades públicas como los interesados en participar en convocatorias o suscribir contratos estatales.

Es así como la contratación estatal no sólo está regida por los principios que explícitamente describe la Ley 80 de 1993: transparencia, economía y responsabilidad, sino también, por los principios que gobiernan la función pública, el derecho administrativo y los principios del derecho privado civil y comercial, en aplicación al principio de legalidad, tal como lo sostiene la Sala de lo Contencioso Administrativo, expediente AP-25000231500020022739 01, Magistrado Ponente: Alier E. Hernández Enríquez, del 31 de marzo de 2005, al expresar lo siguiente: "La aplicación del principio de legalidad a la contratación estatal implica "acercarse tanto a las disposiciones y principios propios del derecho administrativo como a aquellos emanados de las instituciones privadas, civiles, comerciales, etc., dentro de una economía de mercado, donde el Estado es un sujeto más del mismo, en condiciones de igualdad, sin perder de vista el interés general". Por otra parte, la misma Sala de lo Contencioso Administrativo, con ponencia de la Magistrada Ruth Stella Correa Palacio, expediente: 18.403 del 3 de febrero de 2010, sostiene que la contratación estatal es gobernada por los principios del estatuto contractual y por los principios de la función pública. (Rosero, 2011, p.37)

La Exposición de Motivos de la Ley en cita, precisó sobre la inclusión del novedoso Principio de Transparencia para la época que:

Garantiza en primer lugar la imparcialidad y por consiguiente la escogencia objetiva de contratistas aún en los casos de contratación directa o urgente.

También se prevé que los interesados pueden ejercer el derecho de contradicción en los procesos contractuales, y por ello se dispone que las actuaciones de las autoridades sean públicas.

(...) prevé que en los pliegos de condiciones se definan reglas de juego claras y completas que sin duda conducirán a una selección objetiva y a la consecuente confección de ofrecimientos que se ajusten a los requerimientos de los entes 
públicos, evitando así que la entidad se vea abocada a declarar desiertos los procesos de selección. (Gaceta del Congreso de Colombia No. 75, 1992, p.17)

La finalidad de incorporar en el artículo 24 de la Ley 80 de 1993 el Principio de Transparencia en la actividad contractual del Estado, radicaba en fortalecer la imparcialidad en las decisiones derivadas de la escogencia del contratista en los procesos de licitación o concurso y en los casos de contratación directa, con la intención de generar prácticas de probidad en los servidores y proponentes en las diferentes etapas del proceso.

En principio, podría pensarse en que el procedimiento restringido supone una excepción a la concurrencia, comparado en todo su ser con el procedimiento abierto que teóricamente favorece la igualdad de condiciones para todos aquellos que participan en la selección. Sin embargo, tal como se encuentra redactado todo el régimen de contratos de España, y obedeciendo a criterios supranacionales, como los mandatos contenidos en las directivas comunitarias, que de hecho han sido transpuestos en la última reforma de la ley, no nos queda más que afirmar que la concurrencia, en mayor o menor medida, siempre tendrá que estar presente, trátese del procedimiento abierto o de procedimiento negociado. En este último, aunque este postulado no sea de su esencia por facilitar el mecanismo selectivo, de acuerdo con las condiciones que impone la ley, la administración dentro de su práctica administrativa puede introducir elementos de transparencia que coadyuven a que se dé la concurrencia, aunque sea un procedimiento directo, si el objeto de la contratación lo permite. Esto, como ya lo decía el Consejo de Estado Español, debe "inspirar la articulación de procedimientos de selección de contratistas"

En la legislación Colombiana dicho principio queda inmerso en la regla de oro de transparencia (art. $24 \mathrm{ECE}$ ), en que se da por sentado que todos los actos y etapas de la contratación son públicos; en consecuencia, todas las personas pueden conocer dichas actuaciones, y especialmente los participantes. Así, los artículos 24-3 y 24-4. En el artículo 24.2 se preceptúa que los interesados pueden conocer y controvertir todos los informes, conceptos y decisiones que se den en los procesos contractuales; es así como los informes que se hacen para la evaluación de las propuestas quedarán en la secretaria de la entidad correspondiente durante 5 días a fin de que los participantes hagan las observaciones que estimaren pertinentes, de acuerdo con lo que dicta el artículo 30.8. Cuando de Licitación se trate, la propia normatividad consagra los pasos a seguir para la administración a fin de que ésta divulgue de una manera certera la realización de las licitaciones, concursos y ejecución de contratos (Expósito, 2005, p.596) 
La actuación transparente de la gestión contractual pública resulta de un proceder claro y diáfano, que permite conocer las decisiones de la autoridad y acceder a la información en busca de contrarrestar los actos de corrupción.

El concepto de transparencia tiene un doble alcance en el Índice: frente a los miembros de la institución y frente a la sociedad. Una institución es transparente si su misión es conocida, los procedimientos con los que opera son claros para todos los interesados y compartidos por sus miembros, y si sus resultados pueden ser sometidos a un juicio externo. En este sentido, la transparencia en una entidad no sólo se entiende como la publicidad de los actos oficiales sino también como el acceso a la información de la misma, por parte de la ciudadanía en general o de los interesados en particular. A mayor transparencia, mayor visibilidad y, por lo tanto, menor riesgo de corrupción. (Transparencia por Colombia, 2003, p.15)

Con respecto al postulado de Publicidad la Exposición de Motivos del Estatuto de Contratación indicó que:

(...) contempla un régimen de publicidad tendiente a dotar de total transparencia a los procesos contractuales, empezando por la divulgación que está obligada a efectuar la entidad pública de los actos relativos a la apertura de licitaciones, concursos y demás procedimientos reglados de selección mediante su publicación en diarios de amplia circulación en el territorio de su jurisdicción (...)

Así mismo, se otorga la facultad a los oferentes de conocer informes, conceptos y decisiones producidos en el curso del proceso, con el propósito de permitirles la formulación de observaciones (...) para que puedan discutirlos o controvertirlos en orden a preservar la igualdad de oportunidades (...)

En idéntico sentido (...) los informes de evaluación de las propuestas sean puestos a consideración de los proponentes por un término de cinco (5) días para efectos de que formulen las observaciones que estimen pertinentes. Se busca con ello no sólo dar a conocer los estudios de cada una de las propuestas y su evaluación, sino también que los administradores reciban cierta colaboración de los participantes en el proceso de selección, quienes, para el efecto tienen la oportunidad de ilustrar a la administración sobre hechos o circunstancias relevantes y que eventualmente hayan pasado desapercibidas (...)

Un necesario complemento de los instrumentos de publicidad referidos, lo constituye la obligación de (...) suministrar copias de la actuación adelantada y de las propuestas presentadas a cualquier persona que demuestre interés legítimo, 
respetando las restricciones legales derivadas de la reserva de actos o documentos, lo cual constituye una manifestación concreta del derecho previsto en el artículo 74 de la Carta.

En adelante, pues, no habrá lugar a situaciones de misterio y sigilo que generalmente han rodeado la obtención de información que los proponentes están en el legítimo derecho de conocer. (Gaceta del Congreso de Colombia No. 75, 1992, pp.18 - 19)

Las disposiciones de la ley en comento, solo referían en el artículo 30 como regla del proceso de licitación, la publicación en diarios de amplia circulación, norma que no aplicaba en los demás procesos de escogencia del futuro contratista.

La publicidad no sólo se encuentra sometida a la puesta en conocimiento de los distintos procedimientos contractuales que la Administración va a ejecutar, sino que ya en el iter mismo de los procedimientos se debe dar aplicación a dicho postulado, por ejemplo, dando a conocer públicamente las decisiones que se dictaminan en el procedimiento contractual, como que los documentos de una propuesta puedan ser consultados, a no ser que la documentación que se solicita goce de reserva, tal como se reconoce en el numeral 4 del artículo 24 ECE. Este evento, en concreto, ha sido resuelto a través de consulta a la sala del mismo nombre del máximo Tribunal de lo Contencioso Administrativo Colombiano, la cual ha partido de la premisa de que el procedimiento contractual es público en su esencia, y en concreto ha declarado que la nueva normatividad contractual modifico el anterior régimen. (Expósito, 2005, p.594)

El Estatuto también determinó, que los actos expedidos con ocasión de la actividad contractual, salvo los de trámite, serán motivados, con la finalidad de minimizar las decisiones injustas o caprichosas de las autoridades, pues de esta forma los interesados podían conocer, una vez garantizada su publicidad, las razones por las cuales una autoridad adopta una decisión.

La misma Exposición de Motivos reconoce que un "adecuado régimen de publicidad de la actividad contractual de la administración no es por sí solo suficiente para garantizar la imparcialidad, objetividad e igualdad de oportunidades, como tampoco lo es para impedir eventuales decisiones caprichosas o arbitrarias de las autoridades." (Gaceta del Congreso de Colombia No. 75, 1992, p.19) 
Como lo ha sostenido reiteradamente la jurisprudencia del Consejo de Estado, las decisiones en materia de contratación no pueden tener motivaciones secretas ni preferencias que se queden en el fuero interno de los funcionarios y, por ende, los fundamentos en que ellas se apoyaron deben quedar razonadamente expresados.

La administración queda de esta forma vinculada exclusivamente al deber de buscar el cabal cumplimiento de los cometidos estatales inherentes a su actividad contractual, despojándose por lo tanto, de cualquier interés particular o motivación subjetiva que la lleve a incurrir en desviación o abuso de poder.

Cabe agregar que la aplicación práctica de los principios aludidos se orienta, en definitiva, a lograr que la contratación estatal sea eficaz, en términos de alcanzar el fin o propósito público perseguido con la celebración del contrato, y al mismo tiempo que dicha actividad sea un proceso inobjetable desprovisto de toda sospecha de inmoralidad que tan gravemente perjudica a la administración pública. (Gaceta del Congreso de Colombia No. 75, 1992, p.19)

Precisó Expósito (2005) que "las reglas de publicidad, unidas al principio de transparencia, forman parte del procedimiento de contratación estatal" (p.589).

La libertad de concurrencia es uno de los principios tradicionales de la contratación de los entes públicos y persigue una doble finalidad: proteger los intereses económicos de la administración suscitando en cada caso la máxima competencia posible y garantizar la igualdad de acceso a la contratación con la administración (...) La instrumentación del principio, que consagra expresamente el artículo 11.1 LCAP, tiene como presupuesto la publicidad de la contratación, una publicidad que hoy tiene que ser, no solo nacional (en el boletín Oficial del Estado), sino también europea a partir de ciertos niveles presupuéstales. (García - Fernández, 2006, p.716)

La transparencia en los procedimientos de selección en la actividad contractual del Estado, buscaba erradicar los actos de corrupción mediante instrumentos dispuestos para acceder a la información por toda persona, tanto nacional como foránea de manera segura y confiable.

El Informe Global de la corrupción 2004 concluye con estos términos:

"Ningún país en el mundo es inmune a la corrupción política. El problema abarca una variedad de actos cometidos por líderes políticos antes, durante o después de 
dejar el cargo. Incluye actos proscritos por las leyes nacionales e internacionales así como actividades que no son ilegales, pero que tienen una influencia corruptora en el proceso político, como por ejemplo cuando las compañías del sector privado acuden al cabildeo para obtener favores políticos".

Muchos son los escándalos por corrupción política en diferentes partes del mundo. En los últimos años diversos casos están presentes alrededor del financiamiento corrupto de partidos políticos y candidatos. En este aspecto, aunque existen las herramientas necesarias para que los gobiernos mermen el problema, por ejemplo convirtiendo la recepción de donaciones anónimas en actos ilegales, la mayoría de los gobiernos no ha adoptado las salvaguardas necesarias (...) En países como el Reino Unido, Francia, Italia o Alemania este tipo de donativos está prohibido, aunque sólo si superan determinado monto.

La persecución de las prácticas de corrupción política viene siendo tímida o débil ya que con frecuencia los protagonistas, de manera directa o indirecta, son precisamente aquellos individuos en quienes la soberanía popular ha depositado su confianza para que administren el Estado, es decir, los mismos gobernantes, por lo que se amparan en fueros o leyes especiales. (Bautista, 2009, p.29)

La investigación encontró en el periodo del texto primigenio de la Ley 80 de 1993, que los niveles de corrupción en los gobiernos departamentales en los años 2004, 2005 y 2006 (Gráfica No. 1), pasaron del nivel alto al moderado y medio, pero con un porcentaje elevado que implica una tendencia fuerte a los actos de venalidad.

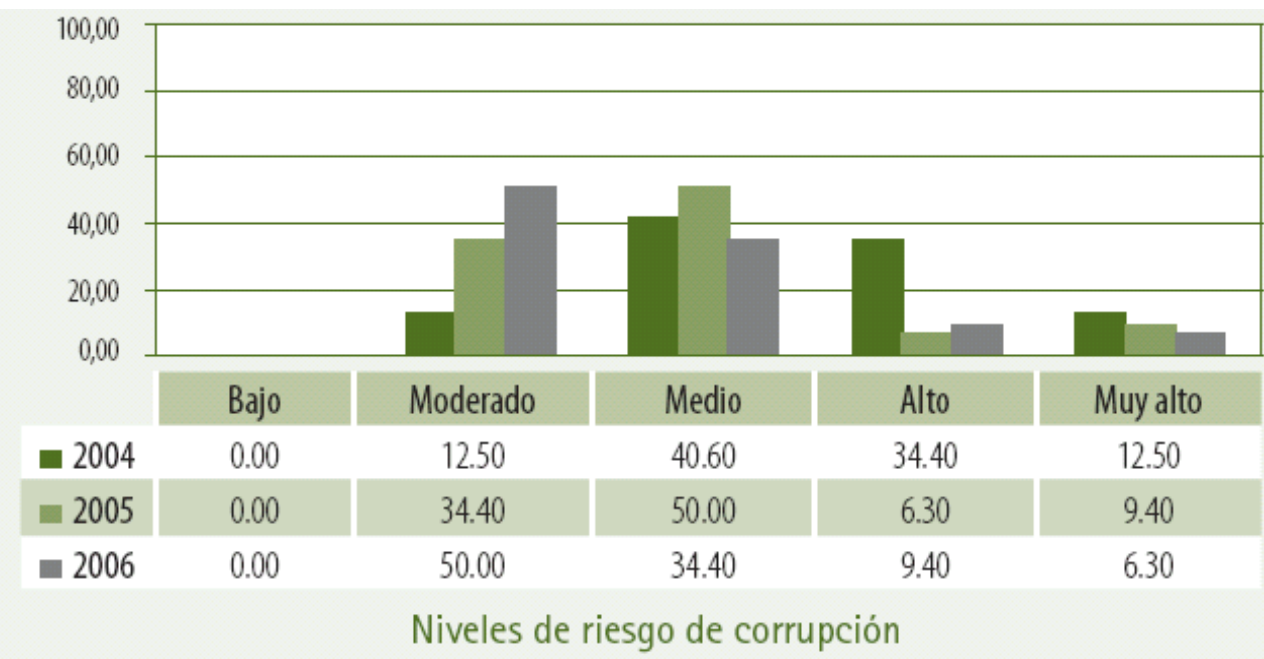

Gráfica No. 1 - Nivel de Corrupción en el Gobierno Departamental

(Transparencia por Colombia - ítd, 2008, p.9) 
Se advierte también en la investigación, que en el mismo periodo, los niveles de transparencia difieren del sector central a los entes descentralizados, mientras en primer orden existen instrumentos que favorecían la transparencia, en el segundo la falta de recursos y de personal especializado, incide en el aumento de conductas de corrupción.

Las fisuras en la configuración de la entidad departamental profundizan el claro desequilibrio institucional y territorial que identifica la estructura estatal en Colombia, es decir, el desarrollo institucional del centro, que a pesar de requerir ajustes, avanza hacia la modernización del Estado, mientras que departamentos y municipios continúan estancados en lo que a institucionalidad moderna y democrática se refiere. (Transparencia por Colombia - ítd, 2008, p.4)

En los entes descentralizados (Gráfica No. 2) advirtió la investigación en el periodo 2004 a 2006, que la tendencia a prácticas de corrupción, a pesar de la leve disminución, se mantiene en nivel alto, medio y moderado, con porcentajes significativos que afectan la transparencia.

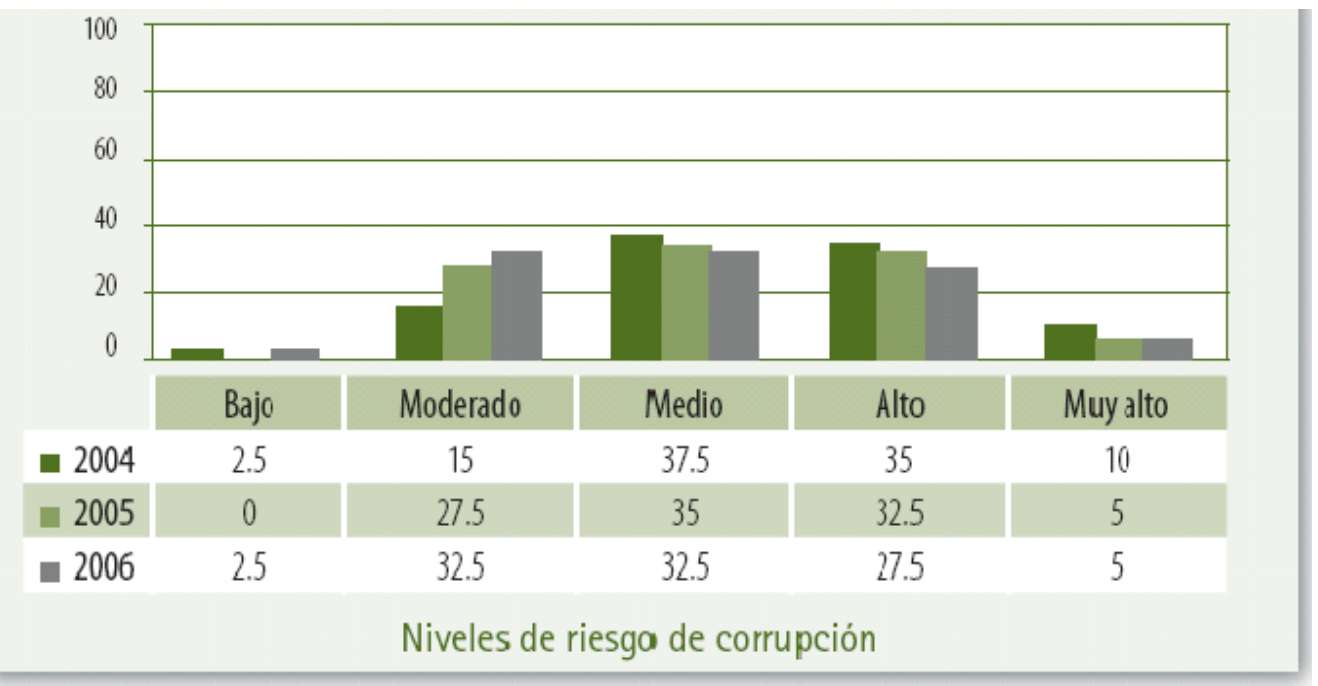

Gráfica No. 2 - Riesgos de Corrupción en Entidades Descentralizadas

(Transparencia por Colombia - ítd, 2008, p.9)

De las gobernaciones evaluadas en la Colección Documentos Observatorio de Integridad No. 8, ítd 2008 de Transparencia por Colombia, se evidenció que solo el $62 \%$ publica los 
pre-pliegos y el $82 \%$ los pliegos definitivos, lo que implica en la diferencia sin publicar que se vulnera el principio de publicidad en los documentos preliminares y se elimina la oportunidad de presentar observaciones a los proyectos de pliegos, lo cual afecta la transparencia del proceso al expedir el acto de apertura sin cumplimiento de las disposiciones legales que para la época, 2003 - 2006, exigían la publicación de los mismos.

¿Qué está pasando? No es un secreto que en los procesos de licitación o invitación pública una de las prácticas más comunes de corrupción es el ajuste de los pliegos para favorecer a ciertos proponentes.

Los 'arreglos', en la mayoría de los casos, son realizados en la etapa de elaboración de pliegos definitivos; razón por la cual la no-publicación de prepliegos facilita alterar las condiciones de las convocatorias impidiendo que los concursantes puedan hacer comentarios e indicar sí las especificaciones están favoreciendo o no la competencia. (Transparencia por Colombia - ítd, 2008, p.31)

La investigación encontró en la Colección Documentos Observatorio de Integridad No. 9, ítm 2008 de Transparencia por Colombia, que se concentra un mayor riesgo en la realización de actos contrarios a la probidad al conformarse un "monopolio de la información y de las decisiones que afectan la colectividad" (p.8).

Ya en su época, A. Smith adoptó una posición crítica marcada de desconfianza frente a los empresarios. Para él, la defensa del capitalismo no consistía en servir a los intereses de los empresarios ni sostener su espíritu de monopólico. Para Smith, su rol sólo se centraba en la utilidad que aportaban a la sociedad al competir en el mercado para ofrecer productos al alcance y beneficio de los consumidores. Sin embargo, entre otros aspectos, se manifiesta una tendencia distinta: se aprovechan de privilegios del Estado para simular la pretendida representación de los intereses sociales que, en definitivas, equivalía a una "conspiración contra el público" y, por ende, un atentado contra el interés general. Sintomática es su famosa advertencia partiendo de la óptica del consumidor:

"No recurramos a su humanidad, sino a su egoísmo, y jamás hablemos de nuestras necesidades, sino de las ventajas que ellos obtendrán".

Promovedor del mercado, defensor de la competencia y la "libertad natural" que aportan mayor crecimiento económico, Smith se opuso enérgicamente a los monopolios. (Lafuente, 2012, p.54) 
La investigación advirtió en la Colección Documentos Observatorio de Integridad No. 8, ítd 2008 de Transparencia por Colombia, que la publicidad en el gobierno departamental se posicionó en el periodo en un nivel bajo, con porcentajes precarios del 6\% (Gráfica No. 3), pese a que en dicho lapso se encontraba vigente el Decreto 2170 de 2002 que determinaba la publicación en la página web de la respectiva entidad, el cual fue modificado por el Decreto 2474 de 2006 que implementó el Portal único de Contratación.

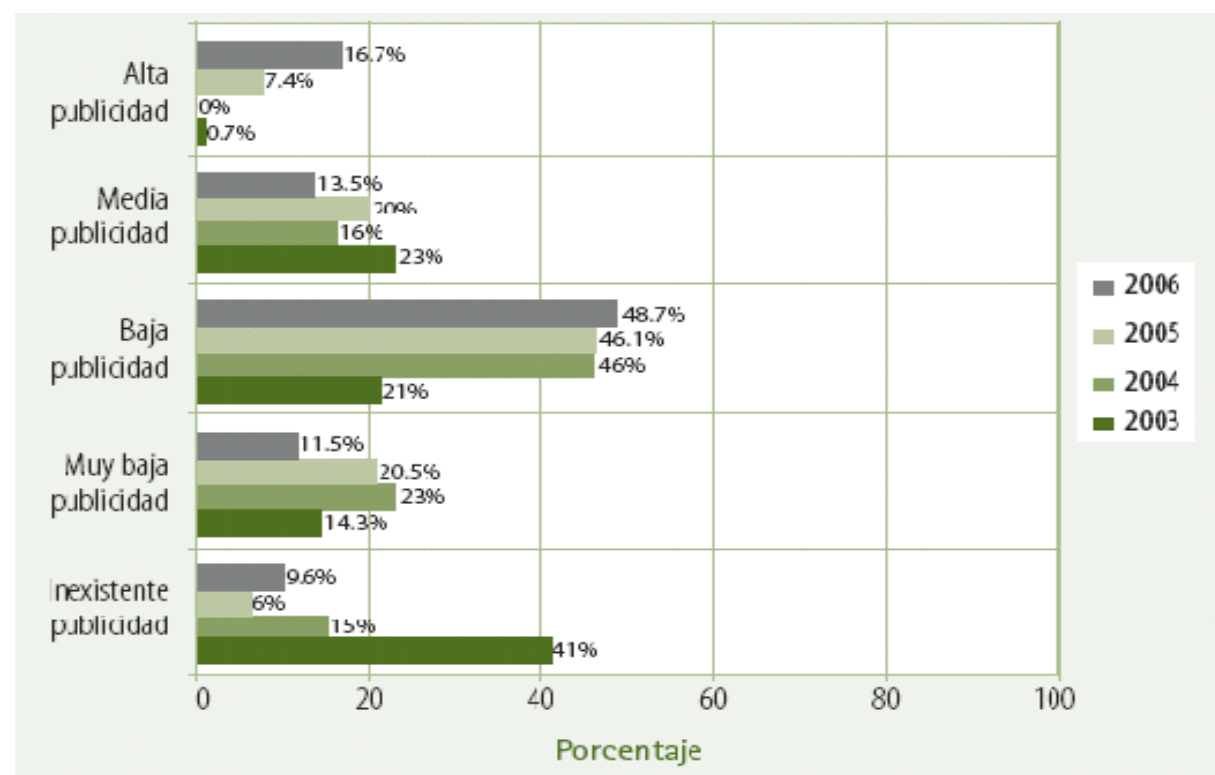

\section{Gráfica No. 3 - Nivel de Publicidad en la Contratación Departamental}

(Transparencia por Colombia - ítd, 2008, p.32)

En la Colección Documentos Observatorio de Integridad - No. 8, ítd 2008 de Transparencia por Colombia, el investigador advirtió, que pese a la realización de convocatorias, en el periodo 2004 - 2006, los procesos no contaron con la publicidad suficiente para garantizar la transparencia en la escogencia.

La palabra transparencia evoca aquello que es traslúcido, que se deja apreciar con total nitidez y, por lo tanto, se puede conocer a cabalidad. La transparencia llevada a la administración pública reclama un ejercicio de cara a la opinión y a los órganos de control. Un poder estatal transparente es aquel que deja ver y acata las reglas 
que habitan el manejo de los bienes e instituciones públicas. También, la transparencia permite el control social y estimula la participación ciudadana y comunitaria. Funciones, reglas, fines y programas de política pueden ser conocidos y popularizados, de tal manera que estimulen las miradas y los esfuerzos por incidir en la construcción colectiva de los poderes estatales. En fin, una administración sometida al escrutinio, respetuosa de las reglamentaciones, permeable al control ciudadano y a la participación social en sus estructuras y fines, aumenta considerablemente la eficacia y eficiencia. (Transparencia por Colombia - ítd, 2008, p.35)

Señaló la Colección Documentos Observatorio de Integridad No. 9, ítm 2008 de Transparencia por Colombia, que el desequilibrio en el desarrollo de las entidades fractura el Estado y genera incertidumbres en su acción y resultados. Los municipios de categoría 5 y 6 en el periodo 2005 - 2006 se ubicaron en un nivel de corrupción muy alto (Gráfica No. 4), categorías que para la época del índice alcanzaban el 93.3\% de los municipios en el país.

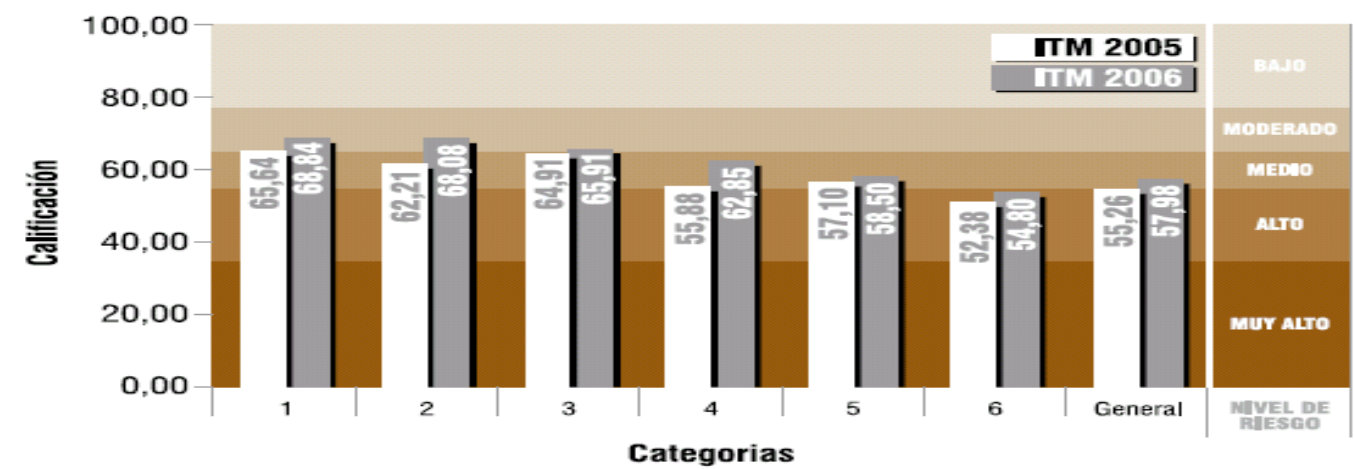

Gráfica No. 4 - Índice de Corrupción - Gobierno Municipal

(Transparencia por Colombia - ítm, 2008, p.9)

En el gobierno municipal la falta de implementación de herramientas para brindar publicidad y la indebida planeación en los procesos de selección propicia prácticas corruptas.

Los medios de publicidad de temas como la contratación pública y el presupuesto municipal no son masivos y de fácil acceso a la ciudadanía.

En términos de la administración y la burocracia local, los municipios aún no desarrollan ni utilizan sus herramientas de planeación a cabalidad. Se observa baja 
utilización de planes operativos y del banco de proyectos (...) siguen presentándose altos porcentajes de contratistas y de personal de apoyo en las administraciones, lo que puede ser síntoma de la existencia de nóminas paralelas, las cuales a su vez generan un crecimiento exagerado de la burocracia local. (Transparencia por Colombia - ítm, 2008, p.8)

La Investigación advirtió, que los niveles de corrupción en el año 2006 (Gráfica No. 5), en promedio son elevados en el orden nacional, seccional y local, lo cual afecta ostensiblemente la transparencia en los procesos de selección, la sana competencia y deja en manos de unos cuantos grupos económicos la contratación estatal.

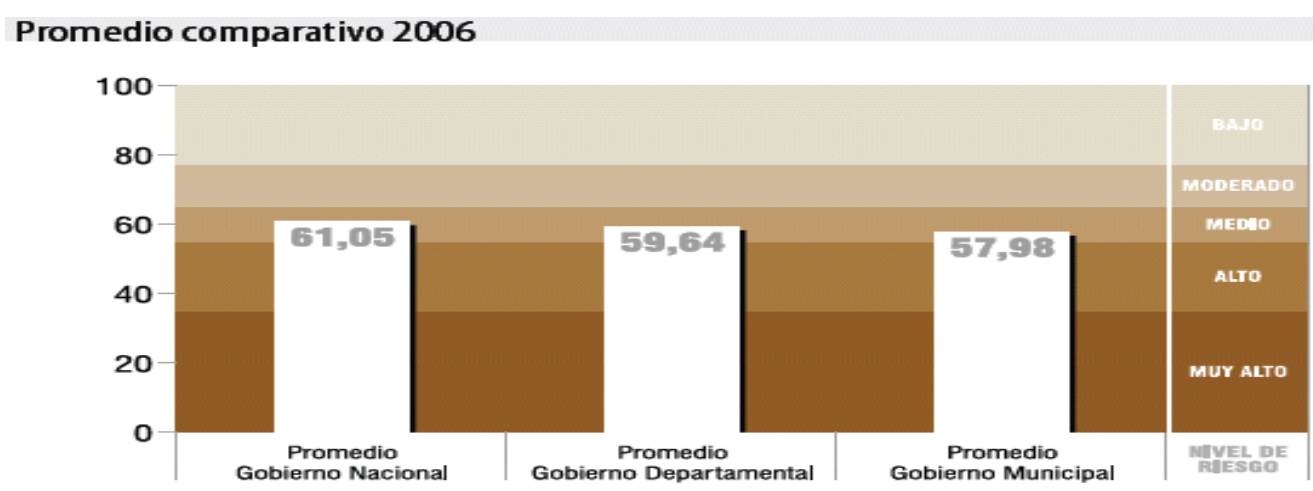

Gráfica No. 5 - Riesgos de Corrupción

(Transparencia por Colombia - ítm, 2008, p.7)

Esto no quiere decir que las entidades nacionales estén en condiciones óptimas de transparencia, aunque sí están mucho más desarrolladas institucionalmente que las entidades regionales y locales, con lo que se siguen aplazando las altas demandas de bienestar económico y social y de democratización de amplios sectores de la nación. (Transparencia por Colombia - ítm, 2008, p.6)

El propósito del capítulo, es enmarcar el principio de transparencia como un paradigma desde el texto primigenio de la Ley 80 de 1993 hasta el año 2006, con la intención de observar el nivel de corrupción local, departamental y nacional, para estructurar el problema jurídico planteado en prácticas que afectan la transparencia en la actividad contractual del Estado, como se advierte de los diferentes informes observados. 


\section{Capítulo 2.}

\section{Resultados del Fortalecimiento al Principio de Transparencia en las Compras Públicas}

Los actos de corrupción en las compras públicas identificados en el capítulo anterior en el nivel local, departamental y nacional, permiten cuestionar la transparencia de los procesos de selección en la actividad contractual del Estado, desde una óptica interna con dimensiones en el contexto internacional por la globalización de los mercados.

Transparencia Internacional define la corrupción como el mal uso del poder encomendado para obtener beneficios privados. Esta definición incluye tres elementos: 1) El mal uso del poder. 2) Un poder encomendado, es decir, puede estar en el sector público o privado. 3) Un beneficio privado, que no necesariamente se limita a beneficios personales para quien hace mal uso del poder, sino que puede incluir a miembros de su familia o amigos.

De manera similar, para Transparencia por Colombia la corrupción se define como el "abuso de posiciones de poder o de confianza, para beneficio particular en detrimento del interés colectivo, realizado a través de ofrecer o solicitar, entregar o recibir, bienes en dinero o en especie, en servicios o beneficios, a cambio de acciones, decisiones u omisiones. (www.transparenciacolombia.org.co, 2014)

Las actuaciones relacionadas con el flagelo de la corrupción, restringen la sana competencia, reducen la transparencia del proceso de contratación y se contraponen a los principios de moralidad y publicidad señalados en el artículo 209 de la Carta Magna.

La venta fraudulenta o las restricciones subrepticias a derechos públicos (permisos, concesiones, contratos públicos, etc.) por parte de políticos y funcionarios, es decir, lo que se conoce como corrupción, entorpece el desarrollo empresarial, no sólo porque aumenta los costos sino, sobre todo, porque crea incertidumbre acerca de la posibilidad de desarrollar determinadas actividades 0 conseguir determinados permisos o contratos. (DANE - ECDE, 2009, p.11)

Transparencia por Colombia, en la Colección Cuadernos de Transparencia No. 15, Primera Encuesta Nacional sobre Prácticas contra el Soborno en Empresas Colombianas, definió el soborno como: 
El ofrecimiento de regalos, préstamos, honorarios o cualquier otro tipo de beneficio, a cualquier persona, a modo de incentivo para realizar un acto deshonesto e ilegal que implica el quebrantamiento de la confianza durante la conducción de los negocios en la empresa. (Transparencia por Colombia, 2008 p.10)

La misma Encuesta determinó, el Índice de Percepción de Corrupción de Transparencia Internacional, realizado en el año 2007 en más de 180 países, con una calificación en una escala de 0 (un alto nivel de corrupción) a 10 (un alto nivel de transparencia), con los siguientes resultados:

\begin{tabular}{|l|c|c|}
\hline \multicolumn{1}{|c|}{ País } & Puntaje 2007 & Posición \\
\hline Nueva Zelanda & 9.4 & 1 \\
\hline Dinamarca & 9.4 & 1 \\
\hline Finlandia & 9.4 & 1 \\
\hline Colombia & 3.8 & 68 \\
\hline Myanmar & 1.4 & 180 \\
\hline
\end{tabular}

Tabla No. 1 - Índice de Percepción de Corrupción 2007

(Transparencia por Colombia, 2008, p.10)

Se evidencia que Colombia presentaba en año 2007 un alto nivel de corrupción, concentrado en prácticas de soborno que identificó la Primera Encuesta, en contribuciones a campañas políticas, pagos por trámites, donaciones, patrocinios, regalos y gastos de representación, entre otros.

Informe Global de Competitividad del Foro Económico Mundial. Señala que en Colombia la corrupción ocupa el segundo lugar en importancia entre los factores que dificultan la realización de negocios en el país. Dato que es corroborado por los resultados de la Línea de Base sobre Responsabilidad Social Empresarial en Colombia - 2006, del Centro Colombiano de Responsabilidad Empresarial, que señala que $31 \%$ de las empresas colombianas consideran que la corrupción es el segundo problema del país. (Transparencia por Colombia, 2008, p.12)

Igualmente, la Primera Encuesta de Transparencia por Colombia señaló, los resultados de la Encuesta Probidad de Confecámaras - 2006, realizada a 1.697 empresarios que 
concurren a licitaciones públicas en 18 ciudades de Colombia, la cual concluyó con los siguientes indicadores:

- $84.4 \%$ de los empresarios se abstiene de participar en procesos de contratación con el Estado, porque considera que la competencia no es justa, que hay politización en el proceso de contratación y pagos no oficiales.

- $79.6 \%$ de los empresarios encuestados desconfía de sus competidores

- $36.8 \%$ de los empresarios considera que la pérdida de valores éticos es la causa más relevante para la existencia de corrupción.

- $31.74 \%$ de los empresarios afirma que en un proceso de contratación con el Estado, los sobornos son solicitados por los funcionarios públicos y $16.92 \%$ considera que el empresario interesado es quien los ofrece.

- $28.4 \%$ de los empresarios recibió algún tipo de solicitud de dinero, favores o regalos a cambio de servicios por parte de un funcionario del Estado. Sólo $8.52 \%$ denunció efectivamente el caso.

- Se estima que el porcentaje promedio que se paga por la obtención de un contrato es $12.91 \%$ del mismo. (Transparencia por Colombia, 2008, p.12)

El Investigador infiere de los anteriores resultados, que la corrupción afecta la transparencia en los procesos de selección y deja en manos de unas pocas personas o empresas debidamente constituidas la contratación del sector público, por la desconfianza en los mismos competidores y la solicitud de sobornos por algunos funcionarios o empresarios que los ofrecen.

Seria ingenuo creer o aceptar que la empresa ha sido la obra del sistema capitalista. En las civilizaciones antiguas u ordenes sociales ya existían formas de "empresas" - primitivas o rudimentarias, como queramos llamarlas - con otras características y estructuras, diferentes a las de hoy, pero, en principio, con el mismo objetivo: los fines lucrativos. Las artesanías de antaño y los intercambios o aventuras en el negocio al fin del mundo han sido el mejor reflejo de ello.

Querer definir una empresa supone aceptar incondicionalmente cinco conceptos indispensables: capital, riesgo, unidad productiva (trabajo), venta y beneficio. La empresa es una entidad creada con capital, bajo el mando del titular dispuesto al riesgo, se dedica a actividades industriales y mercantiles o de servicios para conseguir un lucro mediante la venta en el mercado. Además de conjunto de 
recursos humanos y bienes materiales, se presenta como una unidad de planificación y sistema de coordinación directa y central. El objetivo de la empresa como agente económico debe ser la satisfacción de las necesidades del mercado con bienes y servicios útiles y beneficios para la sociedad. (Lafuente, 2012, p.53)

Se faculta a los particulares para desarrollar determinados actos con un permiso, autorización o licencia, e incluso, no se precisa de esto para el ejercicio de una determinada actividad, industrial u oficio, pues allí opera como regla general la libre iniciativa sin permisos previos. (Cruz, 2011, p.30)

Igualmente, observa que en la actividad contractual del Estado convergen relaciones entre el sector público y el sector privado que implican una serie de actos en los cuales participan personas de ambos sectores, con responsabilidades que difieren desde el punto de vista de la gestión pública y desde el punto de vista social pero que confluyen en la lucha contra la corrupción.

La noción de corresponsabilidad se fundamenta en una concepción de democracia participativa, en la que la gestión pública no se limita a la gestión de las instituciones del Estado sino que incluye la gestión de lo público, entendiendo lo público como aquello que conviene a todos o como "la suma de voluntades, esfuerzos y recursos que tienen como meta el diseño y el cumplimiento de reglas que son de interés general", concibiendo interés general como los asuntos comunes.

Bajo esta concepción, los ciudadanos hombres y mujeres ya no sólo exigen al Estado el cumplimiento de sus obligaciones frente a sus derechos, sino que asumen una serie de deberes frente a la gestión de lo público y la regulación de los beneficios compartidos, teniendo como premisa los valores de equidad y justicia. Dado que lo público es patrimonio compartido, la responsabilidad por su gestión deja de ser exclusiva del Estado, y nace así la noción de corresponsabilidad.

Es en este marco, en el que el sector empresarial asume su responsabilidad en el desarrollo de la sociedad, tanto en la construcción de lo público como en la lucha contra la corrupción, de manera compartida con el Estado y con los demás actores de la sociedad civil.

El sector empresarial, como parte de la sociedad, desempeña un papel fundamental como agente del desarrollo económico y social, e incluso, como actor del control, en la medida en que también posee la capacidad de ejercerlo desde su propio ámbito de acción. 
(...) esta iniciativa de corresponsabilidad, impulsada por la Organización de Naciones Unidas, establece: que "las empresas deben trabajar en contra de la corrupción en todas sus formas, incluyendo la extorsión y el soborno. (Transparencia por Colombia, 2008, pp.13 - 14)

La Primera Encuesta de Transparencia por Colombia, también (Gráfica No. 6), reveló resultados en relación con los empresarios en Colombia que dentro del giro de sus negocios ofrecen sobornos en el sector público y privado.

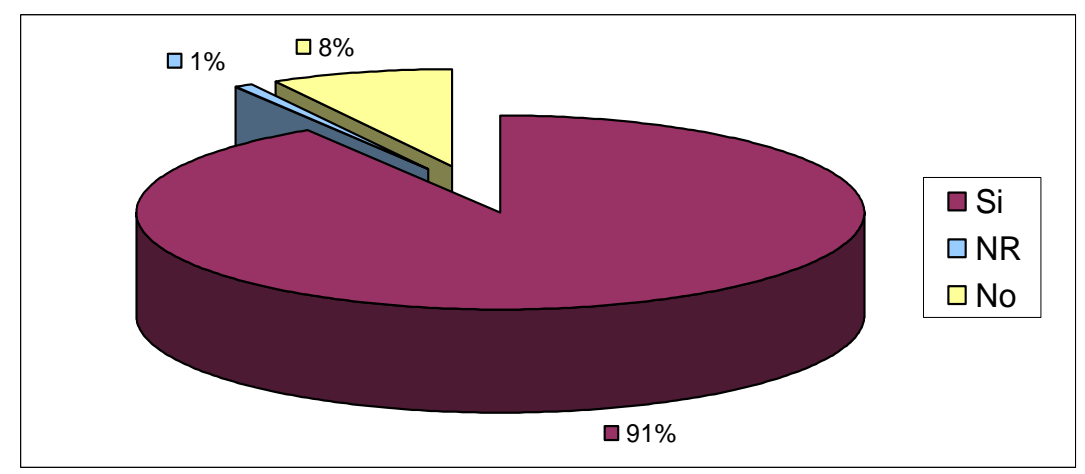

Gráfica No. 6 - Ofrecimiento de Sobornos por Empresarios

(Transparencia por Colombia, 2008, p.33)

Como se observa, los mismos empresarios reconocieron al realizarse la encuesta en el año 2007, que una de las formas de acceder a los contratos tanto en el sector público como privado es a través de sobornos. Resultado que, además, afecta negativamente la libre competencia, la confianza en los mercados y la inversión nacional como foránea.

Se advierte, que la misma encuesta determina como modalidades comunes hasta el año 2007 para sobornar, las contribuciones políticas, pagos para facilitar y agilizar trámites, comisiones, patrocinios, regalos y gastos de representación. (Transparencia por Colombia, 2008, p.34)

Entre los motivos para ofrecer sobornos, el investigador encontró, en la misma encuesta, la constante presencia de prácticas de soborno por parte de la competencia 
y la estrategia comercial para obtener mayor participación en el mercado. (Transparencia por Colombia, 2008, p.35)

El anterior panorama cimienta la expedición de la Ley 1150 de 2007 que fortalece el principio de Transparencia en la actividad contractual del Estado al determinar unas modalidades de selección en consideración al objeto a contratar, por cuanto no es lo mismo adelantar una obra pública, que realizar unos diseños o comprar bienes, por consiguiente, los procedimientos adoptados de escogencia, buscan la eficiencia en la gestión contractual y en la asignación de los recursos públicos mediante reglas que difieren en relación con el objeto a contratar.

En consecuencia, determinó el artículo $2^{\circ}$ de la Ley en cita como modalidades de selección la (i) licitación pública; (ii) la selección abreviada; (iii) el concurso de méritos; (iv) la contratación directa; (v) y la mínima cuantía, contenida inicialmente en la Ley 1450 de 2011 y subsiguientemente en la Ley 1474 de 2011.

El artículo 3ํ de la Ley 1150 de 2007 creó el Sistema Electrónico para la Contratación Pública (SECOP), como herramienta para la gestión contractual, con el propósito de permitir en los términos de la Ley 527 de 1999 la sustanciación de las actuaciones derivadas de la actividad pre-contractual y contractual por medios electrónicos.

La implementación del SECOP buscó garantizar el Principio de la Función Administrativa de Publicidad contenido en el artículo 209 del Estatuto Superior, así como los principios de Publicidad y Transparencia señalados en la Ley 80 de 1993 y las modificaciones efectuadas por la Ley 1150 de 2007, pues a través de esta herramienta se extiende el llamamiento a participar a un mayor número de personas interesadas, no solo nacionales sino foráneas.

El Gobierno Nacional mediante la estrategia Gobierno en Línea, liderada por el Ministerio de las Tecnologías de la Información y las Comunicaciones, para contribuir a la construcción de un Estado más transparente; más eficiente; más participativo; y que 
preste mejores servicios a los ciudadanos y a las empresas, mediante el aprovechamiento de las Tecnologías de la Información y las Comunicaciones (TIC); estableció a través del SECOP una nueva forma de relacionarse o interactuar entre entidades, proponentes, entes de control y ciudadanos, que al usar las TIC eliminan barreras de tiempo y espacio en el acceso a la información y compras del Estado. La publicidad, oportunidad y visibilidad de los documentos originados en la actividad contractual, como estrategia fomentará la transparencia en la contratación pública e impulsará el comercio electrónico en el país.

Los medios electrónicos pueden ser un buen instrumento para hacer efectivos los principios de la contratación en el sector público: libertad de acceso a las licitaciones, publicidad y transparencia de los procedimientos, no-discriminación e igualdad de trato entre los candidatos.

El principal motor del proceso de utilización de los medios electrónicos en la contratación administrativa ha sido la Unión Europea, que en sus últimas directivas sobre la contratación administrativa prevé la utilización de los medios electrónicos en diferentes fases del procedimiento de contratación administrativa como un mecanismo que puede tener un importante impacto en su eficacia, eficiencia y economía. Como confirman las siguientes palabras de la Comisión Europea, la utilización de los medios electrónicos en la contratación administrativa puede suponer un ahorro importante de recursos públicos. (Carrillo, 2008, p.128-129)

EI SECOP se organizó en dos fases, la informativa y la transaccional. Mediante la primera todas las entidades se obligaron a publicar desde enero de 2008 en el migrado Portal Único de Contratación - implementado en el año 2006 por el Decreto 2434 - la información relacionada con los procesos de selección que pretendían adelantar y se estructuraba en los estudios, pliegos, anexos técnicos y demás documentos relacionados con la convocatoria.

Al minimizar las barreras de acceso a la información de las entidades públicas los documentos podían consultarse en la web por los interesados en participar de una manera más ágil, segura y confiable, al mismo tiempo se garantizaba la inmutabilidad de los documentos, por cuanto todo cambio a un documento publicado quedaba 
registrado en la plataforma. EI SECOP se consolida como el sitio oficial de publicación de los actos derivados de la actividad contractual.

La segunda fase, favorece la interacción de los entes públicos y los participantes a través de acciones o comercio electrónico, con la posibilidad de presentar propuestas, observaciones e intervenir en audiencias virtuales. Los primeros pilotos de actuaciones electrónicas se realizaron en el año 2011, con participación de entes del orden nacional y personas interesadas con firma digital certificada por uno de los entes encargados en el país; oportunidades que permitieron realizar audiencias, subastas y otras actuaciones con resultados que beneficiaron tanto a los entes públicos como a los participantes. Todo ello permitió consolidar la plataforma en los términos actuales.

En las primeras subastas, tanto presenciales como electrónicas, se alcanzaron ahorros significativos, lo que evidenció que efectivamente se presentaban sobre - costos en la contratación pública; indiscutiblemente el valor resultante no debe incidir en la calidad de los bienes o servicios, en consecuencia, los estudios del ente contratante deben contemplar condiciones óptimas de calidad, en caso contrario podrían resultar inmersos en hallazgos de responsabilidad fiscal.

Aunado a lo expuesto y con el propósito de fortalecer los instrumentos para luchar contra la corrupción en el ámbito público y privado, el legislativo expidió la Ley 1474 de 2011, por la cual intenta mitigar y prevenir los actos de corrupción en armonía con las reglas internacionales, mediante disposiciones que tipifican la inhabilidad por corrupción (Art. 1); la inhabilidad por financiar campañas políticas (Art. 2); la prohibición para que ex-servidores públicos gestionen intereses privados, también conocida como puerta giratoria, que permitía gestionar ante la entidad donde prestó servicios, asuntos sobre los cuales cumplió funciones (Art. 3); la corrupción privada (Art. 16); la administración desleal (Art. 17); los acuerdos restrictivos de la competencia (Art. 27); el tráfico de influencias (Art. 28); y el soborno transnacional, entre otros, disposiciones que buscan la protección de los recursos públicos y la transparencia en los procedimientos. 
Desgraciadamente, se advierte del texto legal, que la intención del legislador no contempló algunos aspectos que en la práctica hacen nugatoria la protección perseguida, verbigracia, en el tipo de la inhabilidad para contratar con quienes financien campañas políticas solo restringe el financiamiento de campañas a presidente de la república, gobernaciones o alcaldías, sin contemplar las campañas a congreso, asamblea y concejos distritales y municipales.

En lo referente a la publicidad la ley en cita en el artículo 89 señaló que "no podrán expedirse adendas dentro de los tres (3) días anteriores en que se tiene previsto el cierre del proceso de selección, ni siquiera para extender el término del mismo. La publicación de estas adendas sólo se podrá realizar en días hábiles y horarios laborales", disposición desafortunada por cuanto modifica el numeral $5^{\circ}$ del artículo 30 de la ley 80 de 1993, norma que solo se aplica, por así disponerlo expresamente el inicio del mismo artículo, a la licitación, por consiguiente, la intención del legislador no contempló los demás procesos de selección, es decir, la selección abreviada, el concurso de méritos y la mínima cuantía, que alcanzan porcentajes más altos en consideración al número de licitaciones que en un periodo fiscal se realizan en una entidad pública.

En relación con la supervisión e interventoría en los contratos estatales, la ley en cita determina en el artículo 83, la obligación de vigilar la correcta ejecución del contrato con el fin de proteger la moralidad, prevenir los actos de corrupción y favorecer la transparencia, en consecuencia, los supervisores e interventores conforme al artículo 84, podrán solicitar informes, aclaraciones sobre la ejecución y responderán: por no exigir la calidad de bienes y servicios; o certificar como recibida a satisfacción obra que no se ejecutó a cabalidad; o por omitir el deber de informar al ente contratante los hechos que perturben el cumplimiento del contrato o constituyan actos de corrupción. Norma afortunada, por cuanto en la ejecución se reflejan las secuelas de las prácticas indebidas en la etapa de selección, que de no ser advertidas afectan notablemente los objetos contractuales y el erario. El cumplimiento del supervisor o interventor con sus 
obligaciones favorecerá en el mediano y largo plazo en la recuperación de la confianza y legitimidad de las actuaciones públicas, reto que resulta arduo por la politiquería y compromisos previos entre algunos servidores y empresarios, como lo advierten informes que documentaron la investigación.

La Tercera Encuesta Nacional sobre Prácticas contra el Soborno en Empresas Colombianas de Transparencia por Colombia, determinó el índice de Percepción de Corrupción de Transparencia Internacional, realizada en el año 2012 a un total de 176 países, con una calificación en una escala de 0 (percepción sumamente corrupto) a 100 (percepción de muy transparente), en la cual Colombia (Tabla No. 2), obtuvo una calificación deficiente.

\begin{tabular}{|c|l|c|}
\hline Posición & \multicolumn{1}{|c|}{ País } & Puntaje 2012 \\
\hline 1 & Finlandia & 90 \\
\hline 1 & Nueva Zelanda & 90 \\
\hline 4 & Suecia & 88 \\
\hline 5 & Singapur & 87 \\
\hline 9 & Canadá & 84 \\
\hline 15 & Barbados & 76 \\
\hline 19 & Estados Unidos & 73 \\
\hline 20 & Chile & 72 \\
\hline 20 & Uruguay & 72 \\
\hline 69 & Brasil & 43 \\
\hline 94 & Colombia & 36 \\
\hline 105 & México & 34 \\
\hline
\end{tabular}

Tabla No. 2 - Índice de Percepción de Corrupción 2012

(Transparencia por Colombia, 2012, p.12)

En la Tercera Encuesta de Transparencia por Colombia los niveles de corrupción en Colombia son elevados en comparación con Chile y Uruguay que lograron el mismo puntaje con un nivel aceptable. Asimismo, colige el investigador, que el nivel de descomposición o corrupción en sus diferentes manifestaciones, por parte de algunos empresarios y servidores para lograr la adjudicación, aumentó en relación con la Primera Encuesta realizada en el año 2007, lo cual afecta marcadamente la inversión 
nacional e internacional, la confianza en las negociaciones y la transparencia en los procedimientos de selección.

Los niveles de percepción de corrupción en Colombia son muy altos y como lo menciona Transparencia por Colombia, éstos han alcanzado un carácter estructural: "La ausencia de sanciones efectivas y rápidas frente a casos de corrupción y la prevalencia de prácticas de abuso del poder en todas las ramas del poder público y en diferentes estamentos del Estado se reflejan en la baja calificación", además la corrupción "está asociada con el pago de sobornos en la contratación, compensaciones por favores para concretar un negocio o acceder a un servicio público, pero también que se manifiesta en la captura del Estado en sus diferentes niveles, el nepotismo, legislar en beneficio propio. (Transparencia por Colombia, 2012, p.11)

La corrupción es uno de los factores que más obstaculiza la libre y justa competencia en la realización de negocios, tanto a nivel internacional como en Colombia en particular. La confianza en el mercado, la competitividad empresarial y la inversión nacional e internacional se ven afectadas significativamente por el soborno. (Transparencia por Colombia, 2012, p.16)

Igualmente, destacó la Tercera Encuesta de Transparencia por Colombia, como sectores más propensos al soborno: los contratos de obras públicas, los servicios empresariales y el creciente soborno transnacional.

A pesar que el resultado de los datos entre la Tercera Encuesta Nacional Sobre Prácticas Contra el Soborno en Empresas Colombianas no puede ser comparados con la Encuesta de Probidad 2006 de Confecámaras; es significativo que la percepción de los empresarios sobre los montos secretos pagados para asegurar la adjudicación de un contrato sea del $14,87 \%$, valor superior al promedio nacional encontrado en la mencionada encuesta del 2006, la cual se ubicaba en el 12,91\%. Esto puede indicar que los costos de la corrupción en Colombia han aumentado en el periodo 2006-2012.

El Consejo Privado de Competitividad considera que "si bien no existe una fórmula exacta para cuantificar el costo de la corrupción en Colombia, se estima que la corrupción le cuesta al Estado (...) alrededor de 1,6\% del PIB", equivalente en el Presupuesto General de la Nación 2012 aproximadamente a 10,4 billones de pesos. Si se tiene en cuenta que en el 2012 el PIB destinado a Salud es del 2\%; las Actividades y servicios de la defensa nacional y las Actividades de Orden Público y seguridad ciudadana, tiene cada una un $1,5 \%$ del PIB; la transferencia a 
las universidades sin pensiones suma 2 billones de pesos y el presupuesto destinado para las víctimas de la violencia es de 2,9 billones de pesos; se puede dimensionar el tremendo costo de la corrupción para el país. (Transparencia por Colombia, 2012, p.85)

La Tercera Encuesta de Transparencia por Colombia, también evidenció, que se incrementó la percepción de soborno en todas las modalidades, en especial en las contribuciones políticas, pagos por trámites de procedimientos engorrosos. (Transparencia por Colombia, 2012, p.52)

Los empresarios consideran que la corrupción en el sector privado aumentó entre el año 2004 al 2010 incrementándose del 47\% al 52\%. Con una calificación de 1 a 5 , donde 1 es nada corrupto y 5 extremadamente corrupto, el sector privado de Colombia recibió una calificación de 2,9. El 24\% de los encuestados manifestaron haber pagado un soborno en los últimos 12 meses. (Transparencia por Colombia, 2012, p.16)

La percepción del aporte de contribuciones privadas a campañas y partidos políticos aumentó en forma considerable. Las políticas anticorrupción implementadas en los últimos años no han logrado regular las contribuciones privadas a campañas electorales y partidos políticos, en las tres encuestas realizadas estas contribuciones se perciben como una de las modalidades principales de soborno. Esta modalidad presenta un comportamiento creciente de 10 puntos porcentuales para el 2012 (54\%), frente a los resultados del 2010 (...)

Los trámites y procedimientos engorrosos y el requerimiento de sobornos por parte de funcionarios públicos son los principales motivos de presión para la ocurrencia del soborno en el sector público. En el 2012 los empresarios consideraron que el principal motivo para ofrecer sobornos son los trámites y procedimientos engorrosos (55\%) (...). Se mantiene la percepción en la mitad de los empresarios que la segunda causa de presión (en las tres encuestas) es el requerimiento de los funcionarios públicos de sobornos y beneficios en forma directa o indirecta. (Transparencia por Colombia, 2012, pp. 53 - 54)

Ante las situaciones evidenciadas desde la primera encuesta - 2007 que persisten en la tercera encuesta - 2012, el ejecutivo en virtud de las facultades otorgadas por el artículo 75 de la Ley 1474 de 2011, expidió el Decreto Ley 019 de 2012, por el cual suprime o reforma trámites innecesarios en la administración pública, con el propósito 
de racionalizar los trámites y fortalecer en las instituciones la eficiencia, transparencia y moralidad.

Diversos estudios internacionales han visibilizado las dificultades respecto a la realización de trámites en el sector público. El Gobierno Nacional reconoció que se tuvieron en cuenta las recomendaciones del informe "Doing Business 2011" con el fin de facilitar los negocios para la firma del Decreto 19 de 2012 conocido como Ley Antitrámites (facultado por el Estatuto Anticorrupción), con el fin de suprimir o reformar regulaciones, procedimientos y trámites innecesarios existentes en la Administración Pública.

(...) La percepción en el sector privado según la cual si "no se pagan sobornos, se pierden negocios" tiene niveles muy elevados. En el periodo 2010 a 2012, en el entorno de los negocios del sector privado se mantiene en niveles muy elevados la percepción de si no se pagan sobornos se pierden negocios (del 61\% al 62\%)

(...) El clima de los negocios en el sector privado presenta niveles muy elevados de presión para el ofrecimiento o recibo de sobornos, que distorsionan el mercado y llevan a considerar que estas prácticas indebidas hacen parte normal de los negocios en Colombia. (Transparencia por Colombia, 2012, p.55)

El pago de sobornos para acceder a contratos gubernamentales, es condición preliminar en algunas negociaciones, así como la capacidad de influenciar a las autoridades.

La percepción de los porcentajes pagados en forma secreta por la competencia, devela altos costos en la adjudicación de contratos. La mayor parte los empresarios, el $56 \%$, consideran que la competencia para ganar la adjudicación de un contrato tiene que pagar de forma secreta hasta un diez por ciento del valor del mismo, una cuarta parte de ellos, el $25 \%$, entre el diez y el veinte por ciento del contrato, el $12 \%$ de las empresas pagan entre el veinte y el treinta por ciento y los demás encuestados, el $7 \%$, manifestaron que pagan valores superiores del treinta por ciento e incluso se encuentran casos donde el pago excede la mitad del contrato. (Transparencia por Colombia, 2012, p.56)

La percepción entre los empresarios es que los grupos económicos tienen mayor influencia sobre las más altas autoridades $(77 \%)$, seguidos de las compañías multinacionales (53\%) y los gremios económicos (32\%). La influencia de las organizaciones de la sociedad civil es mucho menor que las organizaciones económicas, la más importante es la realizada por las uniones sindicales (15\%). Las asociaciones de profesionales y las ONG tienen una baja influencia sobre las 
altas autoridades, a pesar que estas últimas se convierten en referente para la implementación de políticas anticorrupción, por su legitimidad, independencia, reconocimiento y capacidad de convocatoria. (Transparencia por Colombia, 2012, p.58)

El decreto ley en cita eliminó el Diario Único de Contratación y a partir del primero de julio de 2012 solo se publican los actos derivados de la actividad contractual en el Sistema Electrónico para la Contratación Pública.

Igualmente, modificó la publicación de avisos en diarios de amplia circulación del procedimiento de licitación contemplado en la Ley 80 de 1993, por la publicación de avisos en el SECOP y en la página web de la entidad. La última exigencia es un retroceso, puesto que tal requisito se contempló en el derogado Decreto 2170 de 2002, además constituye un requerimiento, que desnaturaliza con el Decreto Ley 019 de 2012 al pretender erradicar trámites innecesarios, que en el caso en concreto, se convierte en una dualidad que afectan los principios de economía y celeridad.

También, suprimió el Sistema de Información para la Vigilancia de la Contratación Estatal SICE, en el que debían registrarse y pagar el derecho respectivo las personas interesadas en contratar con el Estado.

Asimismo, creó el Registro Único Empresarial y Social -RUES con el propósito de incorporar los diferentes registros de información unificada en el orden nacional como internacional y acreditar ante terceros la calidad de la empresa o persona.

El Gobierno Nacional viene adelantando acciones pertinentes para pertenecer al exclusivo club de buenas prácticas gubernamentales, como es conocida la Organización para la Cooperación y el Desarrollo Económicos OCDE. Este es un proceso largo y de constante evaluación y progreso; en el transcurrir de estos dos años, el país se ha adherido a convenios e instrumentos legales internacionales que obligan a adaptar la normatividad nacional. Es así, como han visto la luz progresivamente el Estatuto Anticorrupción (Ley 1474 de 2011), la Ley Antitrámites (Decreto 19 de 2012) y la "Convención para combatir el cohecho de servidores públicos extranjeros en las transacciones comerciales internacionales" (Ley 1573 de 2012). 
Igualmente, el Gobierno Nacional ha tomado como referente estudios internacionales importantes como las recomendaciones del Doing Business del Banco Mundial e iniciativas de autoregulación como la EITI (Extractive Industries Transparency Initiative) - Iniciativa para la Transparencia de Industrias Extractivas. (Transparencia por Colombia, 2012, p.83)

Pese al fortalecimiento legislativo y reglamentario, el panorama e incidencia de prácticas que afectan la transparencia en la actividad contractual del Estado en Colombia no mejoró, como se advierte en el Índice de Percepción de Corrupción 2014 que puntualizó "El país obtuvo un puntaje de 37 sobre 100 (0 mayor percepción de corrupción y 100 menor percepción de corrupción), es decir, que conserva el puesto 94 entre los 175 países evaluados." 17

Los diseños normativos en contratación se revisan y ajustan, y persiste la diversidad de regímenes de contratación, situación que favorece el desorden y aumenta los riesgos (...) apenas comienzan a percibirse abordajes en temas relacionados con anticorrupción. (Transparencia por Colombia - ítn, 2015, p.5)

El capítulo presenta el fenómeno de la corrupción en el periodo 2007 a julio de 2015, fecha de finalización de la investigación, con el propósito de determinar el flagelo en el espacio antes indicado, a partir de mediciones internacionales en los años 2007, 2012 y 2014, lo cual permitió evidenciar que pese a la incorporación de disposiciones para fortalecer la transparencia en la actividad contractual, los niveles de corrupción aumentaron considerablemente al año 2012 y se mantienen a 2014, por incidencia de prácticas o hechos que afectan la transparencia de los procedimientos como se advierte en los informes de organismos que documentaron la investigación. 


\section{Capítulo 3.}

\section{Prácticas que afectan la Transparencia en la Actividad Contractual Pública}

Las regulaciones legislativas, los desarrollos reglamentarios y la incorporación de tecnologías de la informática en la actividad contractual del Estado propician el ambiente para acceder a las compras gubernamentales en igualdad de condiciones, toda vez que la información de los procesos que pretenden adelantar los entes oficiales se publica en el Sistema Electrónico para la Contratación Pública (SECOP) para su consulta por toda persona nacional o foránea que se encuentre interesada en participar en la convocatoria respectiva, siempre y cuando, cumpla con los requisitos exigidos en el pliego de condiciones.

La agenda del presente exige construir los nuevos mapas de la interconexión, conocer la nueva geografía científica y los nuevos mercados y espacios de la cultura del trabajo. El hombre es elevado a la categoría de "ciudadano del mundo", las distancias se acortan y las capacidades se prolongan. Todo ello importa un desafío para la Política, el Derecho y la Economía, de modo que el Derecho Administrativo se ve obligado a reformular sus instituciones básicas, fundamentalmente en materia de acción administrativa (contratos, fomento y servicios) para mantenerse al día con las exigencias de la sociedad. En esa instancia el contrato público adquiere un nuevo significado, desde lo internacional, como acceso a la globalización. Desenvolverse en mercados aislados o en mercados integrados como el Mercosur, cerrarse en el localismo o actuar en la multilateralización comercial como en la Organización Mundial del Comercio, son elecciones de los Estados que importan una postura hacia lo internacional y lo global y una nueva forma de encarar la contratación pública. La identidad comunitaria e internacional supone coordinar, armonizar y compartir objetivos y estrategias de desarrollo. La escala internacional se plasma en la concertación país-país, país -organismos internacionales, país - potencias líderes. Así, la internacionalización de la contratación pública se verifica también en la aprobación de las Convenciones Interamericana contra la Corrupción (ley 24.759), sobre la Lucha contra el Cohecho de Funcionarios Públicos Extranjeros en las Transacciones Comerciales Internacionales. (Dromi, 2008, p.32)

En materia de Transparencia el DANE en la ECDE - 2009 determinó que los "directivos de empresas nacionales pueden influenciar a través de pagos extraoficiales las 
decisiones del Estado" (Gráfica No. 7), regla que también se puede predicar de los directivos de entes públicos de los diferentes niveles y sectores en el país.

\begin{tabular}{lrrrrrr}
\hline $\begin{array}{l}\text { Los siguientes actores pueden influir, a } \\
\text { través de pagos extraoficiales, en las } \\
\text { decisiones del Estado: }\end{array}$ & $\begin{array}{r}\text { Totalmente } \\
\text { de acuerdo } \\
\text { (\%) }\end{array}$ & $\begin{array}{l}\text { Parcialmente } \\
\text { de acuerdo } \\
\text { (\%) }\end{array}$ & $\begin{array}{c}\text { Parcialmente en } \\
\text { desacuerdo } \\
\text { (\%) }\end{array}$ & $\begin{array}{r}\text { Totalmente en } \\
\text { desacuerdo } \\
\text { (\%) }\end{array}$ & $\begin{array}{r}\text { NS/NR } \\
\text { (\%) }\end{array}$ \\
\hline Directivos de empresas nacionales & 33,7 & 35,2 & 8,8 & 13,2 & 9,1 \\
Sindicatos de trabajadores & 22,4 & 32,4 & 13,3 & 20,6 & 11,2 \\
Gremios & 28,5 & 34,7 & 10,4 & 17,0 & 9,4 \\
Empresas multinacionales & 35,4 & 33,6 & 8,9 & 12,9 & 9,3 \\
Grupos al margen de la ley & 29,4 & 27,4 & 11,4 & 19,7 & 12,1 \\
Organizaciones sociales & 16,6 & 26,3 & 17,0 & 27,7 & 12,4 \\
\hline
\end{tabular}

\section{Gráfica No. 7 - Influencia de Pagos Extraoficiales}

(DANE - ECDE, 2009, p.30)

En palabras de Villanueva (2012), "Los negocios más productivos no dependerían de la competitividad de las empresas sino de su capacidad de influir en los responsables de tomar las decisiones sobre la regulación o el destino de los fondos públicos" (p.18).

Se advierte en la Colección Documentos Observatorio de Integridad - Índice de Transparencia Nacional itn - 2011 de Transparencia por Colombia, que para el periodo 2008 - 2009 los procesos de contratación no son lo suficientemente públicos en el orden nacional; que persisten debilidades en la publicación de la información contractual; que la participación en licitaciones públicas es mínima (Gráfica No. 8); y que más del $50 \%$ de los funcionarios son de prestación de servicios, lo cual genera riesgos de manejo político.

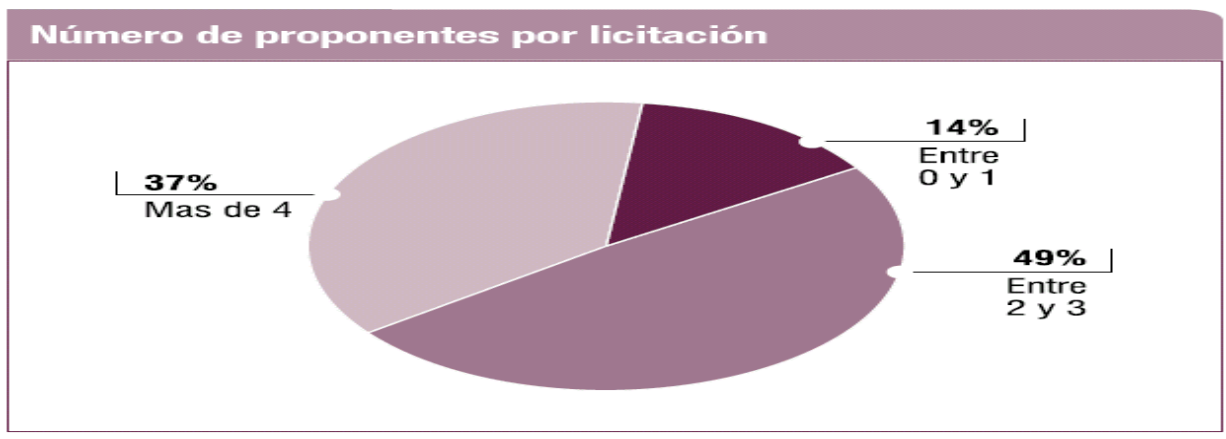

Gráfica No. 8- Porcentajes de Participación en Licitaciones

(Transparencia por Colombia -ítn, 2011, p.29) 
Se advierte de la gráfica que en el periodo $2008-2009$, en el $14 \%$ de los procesos de licitación no se presentaron interesados o tan solo uno participa, lo cual concluye en la declaratoria de desierta por ausencia de oferentes o porque la única oferta no cumple con los requisitos exigidos en el pliego. Ello podría indicar también, la rigidez de los requerimientos por ajustes previos de los pliegos como lo señalan los informes de organismos que documentaron la investigación.

Conforme a la investigación desarrollada la transparencia se afecta por prácticas de algunos actores en la actividad contractual del Estado, en las que sobresalen, la desconfianza en las relaciones contractuales y en los competidores por pagos no oficiales; el desconocimiento de las normas por los actores; la inseguridad jurídica por las constantes modificaciones o derogatorias; la ausencia de sanciones efectivas y rápidas de la administración de justicia; las prácticas de abuso de poder en todas las ramas del poder público; la omisión en denunciar actos de corrupción o sobornos solicitados $u$ ofrecidos para obtener un contrato o los montos secretos pagados para asegurar la adjudicación; los acuerdos previos entre algunas entidades estatales y empresarios dirigidos al ajuste o arreglo de pliegos antes de su publicación para favorecer proponentes; los trámites engorrosos que culminan en pagos extraoficiales; la pérdida de valores éticos; el financiamiento corrupto de partidos políticos o candidatos, así como politización en los procesos.

La intención del ejecutivo de fortalecer la transparencia, se evidenció en febrero de 2015 por la Secretaria de Transparencia de Colombia, al realizar el lanzamiento de la iniciativa Empresas Activas en Cumplimiento Anticorrupción (EACA), con el apoyo de EUROsociAL, para implementar un registro de empresas privadas, con el propósito de fortalecer transparencia en los procesos, robustecer la competitividad del país y prevenir las prácticas corruptas con estándares internacionales, conforme a referencias en el "Registro de Empresas Pro-Ética" de Brasil. ${ }^{18}$ 
El modelo brasileño determina responsabilidad en las empresas por actos derivados de prácticas corruptas contra la administración tanto nacional como extranjera, con aplicación a todo tipo de persona jurídica, sin excluir la responsabilidad individual de administradores o persona natural que contribuyó al acto. ${ }^{19}$

Disposiciones que buscan la interacción de la empresa privada y de la sociedad civil, con el propósito de unir esfuerzos en la lucha contra las prácticas corruptas, para lo cual se requiere el concurso efectivo de los diferentes actores de los procesos contractuales públicos, en la promoción de las estrategias anticorrupción, en la prevención de la corrupción y en minimizar los efectos derivados por tales actos en el contexto internacional.

En tal sentido, la Cámara Colombiana de la Infraestructura (CCI) realiza importantes aportes dirigidos al Sector Público, que comprenden aspectos percibidos en el orden nacional y territorial, con el propósito de contribuir, a través de una infraestructura moderna en el desarrollo socio económico del país. (Cámara Colombiana de Infraestructura, 2012)

En consecuencia, considera relevante la $\mathrm{CCl}$, la planeación estratégica en los procesos de selección, la interlocución permanente del sector tanto público como privado, el cumplimiento de las disposiciones y las relaciones contractuales equilibradas, para lo cual propone al Gobierno Nacional que se adopte una política pública que estandarice y generalice las buenas prácticas en la actividad contractual del Estado. (Cámara Colombiana de Infraestructura, 2012)

En sus recomendaciones destaca la importancia de la Ley 1474 de 2011 en el fortalecimiento de la etapa de planeación; así como del principio de planeación; de las actividades, roles y responsabilidades relacionadas con la supervisión o interventoría en la ejecución contractual; de la elaboración adecuada de la matriz de riesgos; y del manejo de anticipos, que en episodios de diferentes contratos celebrados en el país 
culminaron en situaciones ajenas al contrato e ilegales como lo advirtieron los entes de control. (Cámara Colombiana de Infraestructura, 2012)

Igualmente, la $\mathrm{CCl}$ señala que Colombia debe fortalecer la industria local de ingeniería por su importancia en la productividad, en la innovación, en el crecimiento del país y en los costos de transporte, aspectos en los cuales, según el Índice Global de Competitividad 2014 (WEF),

Colombia resulta en el puesto 85 entre 151 países en la capacidad para innovar, en el puesto 82 por la calidad de sus instituciones de investigación científica, en el lugar 84 por su gasto privado en investigación y desarrollo (...) 'Infraestructura de Transporte', el país permanece sistemáticamente dentro del $50 \%$ de los países a los que les va peor en este benchmarking internacional. (Meléndez, 2015, p.9)

La transparencia también se afecta, por la discrecionalidad que existe en las entidades públicas, para determinar las condiciones de acreditación de experiencia, por la forma en la cual se exige el cumplimiento de los diferentes criterios en los pliegos de condiciones, al respecto la $\mathrm{CCl}$ en los contratos de obra señaló:

No siempre se reconoce la experiencia adquirida como subcontratista, como si quien pudiera reclamarla fuera únicamente el titular del contrato y no todas las firmas y personas que efectivamente lo construyeron y colaboraron en él. Esta es una práctica que va en contra de los más pequeños y que los deja sistemáticamente fuera del sistema de compras públicas en las regiones. (Meléndez, 2015, p.16)

En la causal de Menor Cuantía se restringe la participación, con la atribución otorgada a las autoridades por las disposiciones aplicables, que determinan que en el evento de presentarse más de diez (10) interesados, el ente contratante puede continuar el proceso o hacer un sorteo para seleccionar máximo diez (10), opción por la que normalmente opta la administración y que eventualmente excluiría a proponentes con capacidades para cumplir, al respecto la CCI indicó:

Esta es una disposición que desconoce las bondades que tiene la competencia para regular un mercado y acercarlo al equilibrio más eficiente. Mientras más 
jugadores compitan por un mercado, mejor. Más aún, al excluir por sorteo a potenciales oferentes se corre el riesgo de dejar fuera del proceso a los proveedores más idóneos. (Meléndez, 2015, p.21)

La posibilidad de las entidades públicas de establecer en los requisitos habilitantes la acreditación de la capacidad financiera, en ocasiones limita la participación, por cuanto la forma de exigir los indicadores no es proporcional al objeto del contrato a desarrollar o a las condiciones del mercado o a la realidad de la industria.

Estos criterios numéricos desconocen la realidad de la industria y su modo de operar y provocan la exclusión - de los procesos de contratación - de un gran número de jugadores, ya que en general los proyectos de infraestructura requieren de financiamiento externo y durante su ejecución es normal observar índices altos de endeudamiento. (Meléndez, 2015, pp.16 - 17)

Adicionalmente, la transparencia se afecta ostensiblemente por la conformación de cárteles como lo señala la OCDE, integrados para presentar ofertas en contrataciones tanto en el sector público como privado, los cuales resultan muy difíciles de detectar por la implicación de muchas empresas, por tanto la OCDE, invita a los países a que adopten el programa clemencia, que proporciona inmunidad o reducción de sanciones a miembros del cártel que colaboren - whistleblow -, así como endurecer las condenas, multas y demás medidas que se incorporen al ordenamiento para prevenir que los empresarios ingresen a un cártel. ${ }^{20}$

El programa clemencia se ha implementado en la mayoría de países de la OCDE con resultados importantes en la detección de cárteles, que van desde la prevención para disuadir a los empresarios en la integración de cárteles y la imposición de fuertes sanciones a quienes conformen cárteles consistentes en multas o prisión. ${ }^{21}$

La OCDE sugiere que el combate a la colusión entre oferentes en procesos de Contratación Pública en Colombia se podría beneficiar enormemente si se diera buena difusión a un caso en el que los individuos responsables fueran enviados a prisión. 
El programa de clemencia relativamente nuevo en la SIC todavía no ha generado ningún caso. Esto posiblemente se deba a una cultura en la que los individuos son reacios a acercarse a autoridades para el cumplimiento de la Ley con información y pruebas de una actividad ilegal. (OCDE, Competition Commttee, 2014, p.18)

En el caso colombiano, se recuerdan ciertos episodios, de cárteles que han proliferado en el ámbito contractual gubernamental, en asuntos conocidos por la opinión pública en las relaciones originadas en cuantiosos procesos contractuales, así como en el sector privado con los sonados temas en el cártel de los pañales y de la leche.

Algunas de las prácticas de los actores en la actividad contractual del Estado, señalados en los informes que documentaron la investigación y que afectan ostensiblemente la transparencia de los procedimientos, se presentaron en los hechos que dieron lugar a la Sentencia de la Corte Suprema de Justicia, Sala de Casación Penal - Sala de Juzgamiento, SP14623-2014, Rad. 34282 de 2014, proferida con ocasión de la declaratoria de responsabilidad penal de Nestor Ivan Moreno Rojas, en lo que se denominó el carrusel de la contratación de Bogotá, providencia que evidenció:

En la declaración rendida por Emilio Tapia Aldana (...) queda claro que él representaba los intereses de NÉSTOR IVÁN MORENO ROJAS y en tal condición llegó a acuerdos con los Nule dentro de todo un contexto de compromisos para garantizar la adjudicación de los contratos en razón a la injerencia del Senador sobre la Directora del IDU (...)

Esta revelación permite inferir que el entonces Senador realizaba verdaderas gestiones de intermediación con unas finalidades precisas, lo cual concluyó en el delito de tráfico de influencias, con independencia de que para lograr el propósito final de todo este plan que era la adjudicación de contratos a los Nule y hacerse a gran parte de los anticipos con los que se pagaron las comisiones ofrecidas (...)

Tapia Aldana hizo alusión (...) se reunió en varias ocasiones con NÉSTOR IVÁN MORENO ROJAS, tanto en Bogotá como en los Estados Unidos, pero «solo lo hacíamos él y yo», reuniones en las cuales trataban (...) temas de contratación (...) es posible concluir que este testigo es uno de los principales protagonistas de lo que se ha denominado el carrusel de la contratación de Bogotá y que por tanto su conocimiento sobre los hechos y la participación del acusado en los mismos es de primera mano. (...) Resulta verdaderamente importante su declaración, pues con ella se comprueba que en efecto fungía como vocero y representante de NÉSTOR IVÁN MORENO ROJAS y su hermano Samuel Moreno Rojas en todo lo 
relacionado con acuerdos o pactos derivados de la licitación de malla vial (...) para lo cual el Senador influenció a Liliana Pardo Gaona.

La condición de representante de los Moreno Rojas la ostentaba Emilio Tapia públicamente, sin guardar recato alguno. (...) aseguró éste que había efectuado una inversión cuantiosa de dinero en la campaña del Alcalde Moreno y por ello tenía abiertas las puertas de la contratación de Bogotá, además de alardear sobre su amistad con funcionarios de alto nivel del IDU (...)

Mauricio Galofre Amín (...) respondió: «me dijo -refiriéndose a Emilio Tapia-(...) soy amigo de IVÁN (...) soy la persona que maneja la contratación aquí, y no solo me lo dijo sino de alguna manera me lo demostró adjudicando los dos contratos de malla vial, en principio quedando de últimos en la elegibilidad, demostrando así el manejo de la entidad».

(...) concluye esta Sala de Juzgamiento que las manifestaciones de Emilio Tapia Aldana sobre su relación íntima con NÉSTOR IVÁN MORENO ROJAS y el Alcalde de Bogotá no eran simples expresiones de quien se estuviera arrogando abusivamente una calidad que no tenía, sino que estaba haciendo gala de su verdadera capacidad de influencia en el IDU y alardeaba de ella. En otras palabras, real y verdaderamente lo unía a los hermanos Moreno Rojas un estrecho vínculo, en razón del cual éstos le habían confiado su representación y vocería que en el ámbito de las ilícitas componendas y negociaciones que venía realizando (...) su testimonio resulta creíble a la hora de demostrar que NÉSTOR IVÁN MORENO ROJAS se aprovechó de su investidura, a fin de que se materializa el interés que el Senador tenía de obtener un porcentaje de los anticipos que se desembolsarían al grupo Nule una vez les asignaran los contratos (...)

En conclusión, un análisis conjunto de las declaraciones de Julio Gómez González y Emilio Tapia Aldana, demuestra la capacidad de influencia en el Distrito Capital de NÉSTOR IVÁN MORENO ROJAS, pero especialmente la cualificación de Tapia Aldana como representante de los intereses de los hermanos Moreno Rojas. Testimonios contrastados y merecedores de credibilidad por provenir nada menos que de dos de los principales contratistas de obras públicas que para ese momento tenía la capital de la República.

La sentencia determina claramente, la figura de representación del congresista a través de un tercero, para efectos de adquirir compromisos, acuerdos o pactos que permitieron manipular la adjudicación, con la intervención de funcionarios a cargo de procesos contractuales y futuros contratistas; la injerencia de la investidura de congresista sobre funcionarios del IDU resultó determinante para el propósito perseguido en la componenda, al igual que la financiación de campañas políticas como elemento que 
garantizaba el acceso a la contratación. También destacó la misma providencia:

Procuraduría (...) Miguel Nule Velilla (...) comenzó por dejar en claro que su propósito al rendir testimonio era «desmantelar una organización criminal enquistada en el poder público. Específicamente en el Distrito Capital»(...)

Es precisamente en este instante cuando para esta Sala de Juzgamiento NÉSTOR IVÁN MORENO ROJAS actualizó el tipo penal consagrado en el artículo 411 del Código Penal -tráfico de influencias-, concretando una independiente y autónoma conducta que afrenta la moralidad y trasparencia de la administración pública, puesto que a no dudarlo cuando el procesado le hace el indebido requerimiento a Liliana Pardo, no solamente abusa de su cargo sino que ejerce una influencia sicológica determinante sobre ella para que acceda a su pretensión debido al poder burocrático que ostentaba en ese Instituto, del cual ya había dado muestras contundentes, pues meses antes había intervenido para que fuera ratificada como Directora del IDU.

(...) «la influencia puede ser en cadena; es decir entre quien influencia y el influenciado no hay una relación directa, pero prevaliéndose de su condición logra la determinación de otro funcionario ante el influenciado» (CSJ AP 27 Abr. 2011 rad. 30682), es decir que es posible que el funcionario influenciador utilice terceros para exteriorizar su intención, tal como sucedió en este asunto (...)

Miguel Nule Velilla (...) detalló la manera como se direccionó la licitación del IDU (...) Dijo que la "media aritmética» fue uno de los mecanismos que se utilizaron para seleccionar a los contratistas, y con el cual se logró que se le adjudicaran los contratos al grupo Nule (...) también señaló que Álvaro Dávila Peña le trasmitió cuál iba a ser el porcentaje que sobre el contrato ellos tendrían que pagar y que se fijó en un $8 \%$ ascendiendo dicha proporción a los 180 mil millones de pesos, que se distribuiría un 2\% para el Contralor Distrital, Miguel Ángel Moralesrussi, y el 6\% para «los Moreno» (...) Igualmente dijo que se enteró que la distribución de la comisión sería un $4 \%$ para los Moreno, $2 \%$ para el contralor distrital y $2 \%$ para otros compromisos, en los que estaban Liliana Pardo e Inocencio Meléndez, como funcionarios del IDU (...)

Mauricio Galofre Amín también se refirió a la manipulación de los pliegos de condiciones. Dijo que Julio Gómez González lo puso en contacto con Diana Paola Patiño, empleada de este contratista, con el objeto de que ajustaran los pliegos de condiciones, motivo por el cual se le hicieron modificaciones con el fin de restringir la participación de otros proponentes y facilitar la participación del grupo Nule en el mayor número de propuestas posibles.

Concretamente señaló que los ajustes a los pliegos de condiciones se hicieron en los siguientes aspectos: (i) subir el patrimonio; (ii) se bajó el cupo del crédito; (iii) se 
modificó el tema de la experiencia en Colombia en razón a que la experiencia requerida era en construcción de vías urbanas y solamente la tenían las empresas INCA y COSTCO, propiedad de Julio Gómez (...)

Agregó que con ello solamente era necesario «rechazar» algunos proponentes, lo cual se logró con la ayuda de Manuel Pastrana quien era funcionario del IDU pero laboraba realmente al servicio de Julio Gómez y Emilio Tapia (...)

Dentro del pliego de condiciones se establecen unos requerimientos (...) se restrinja la participación de proponentes y se direcciona hacia las empresas que acceden a la exigencia (...) colocando requisitos dentro de los pliegos de condiciones que cumplan pocas empresas. Para el caso de Malla Vial como uno de los requisitos era una exigencia de experiencia en contratos de vías urbanas en Colombia, eso cómo lo restringía, son pocas las empresas que pueden acreditar una experiencia en vías urbanas de Colombia por el valor que se pidió en los pliegos (...) con esto se evitaba que vinieran empresas del extranjero solas a participar en la licitación pues necesitaban acreditar una experiencia en Colombia. Esa experiencia para efectos de nosotros la única persona que la tenía era el doctor JULIO GÓMEZ.

Se advierte del fallo, que la discrecionalidad del ente contratante para determinar los requisitos de participación, excedió los fines buscados por el constituyente y el legislador, al utilizarse para estructurar reglas en los pliegos que permitían la exclusión de la participación y el claro direccionamiento del proceso de selección, exigencias que afectaron ostensiblemente el principio de moralidad y de transparencia. También señala la decisión en cita de la Jurisdicción Ordinaria:

El pago de estas obligaciones de las cuales se alcanzó a pagar una parte, alrededor de cuatro mil millones de pesos, se hicieron a través de las empresas de JULIO GÓMEZ y EMILIO TAPIA, las empresas eran Constructora INCA y GEOS CONSULTING, los pagos se hacían como unos supuestos subcontratos de obra, que no se realizaban porque los dineros iban destinados al pago de la comisión... estos dineros fueron entregados a EMILIO TAPIA y a JULIO GÓMEZ a través de estos subcontratos ellos siempre dijeron que estos dineros eran con destino a los hermanos MORENO, IVÁN Y SAMUEL (...)

Con estas referencias, se puede afirmar la confluencia de intereses en el propósito de manipular la contratación para lo cual el Grupo Nule encabezado por Miguel Nule, dispuesto a pagar sumas de dinero, contactó a NÉSTOR IVÁN MORENO ROJAS para que éste valiéndose de su posición como Senador, y hermano del Alcalde, influenciara a los funcionarios del IDU e hiciera las gestiones necesarias para la adjudicación de los contratos, oferta que sin ambages fue aceptada por 
NÉSTOR IVÁN MORENO ROJAS, luego de lo cual les manifestó cuál iba a ser el precio por su gestión y que finalmente se fijó en el $6 \%$ del valor total de los contratos.

(...) no puede olvidarse que quien dio inicio a todo este acontecimiento de corrupción, fue justamente el Grupo Nule ante su interés de obtener contratos con el Distrito Capital manipulando los procesos licitatorios, debiendo para ello buscar funcionarios públicos que estuvieran dispuestos a ejercer su poder político para tal propósito, siendo claramente conscientes de que dichos servidores actuarían a su favor solo a cambio de importantes sumas de dinero, de donde es evidente que el ofrecimiento de la dádiva al aquí acusado provino de Miguel Nule y sus socios (...)

Hasta aquí queda claro que al unísono Miguel y Manuel Nule Velilla, Guido Nule y Mauricio Galofre, confirmaron el acuerdo al que llegaron con Álvaro Dávila y Emilio Tapia, representantes de NÉSTOR IVÁN MORENO ROJAS, sobre el porcentaje que sobre los contratos debían pagar, para lo cual resultaba imperioso que se adjudicaran los contratos a las uniones temporales luego de acomodarse los procesos licitatorios a las propuestas presentadas por sus socios (...)

Lo anterior es precisamente lo que lleva a la Sala a afirmar que NÉSTOR IVÁN MORENO ROJAS sí fue determinador del delito de interés indebido en la celebración de contratos, pues sin tener la facultad legal y jurídica de adjudicar contratos ni de evaluar propuestas, aprovechando su posición preponderante como Senador del Polo Democrático, indujo a los funcionarios del IDU -entre ellos Liliana Pardo- a que realizaran todas las gestiones necesarias para que el Grupo Nule resultara beneficiario de los contratos de la malla vial. Así lo refirieron claramente Emilio Tapia y Julio Gómez (...)

Tal como lo señaló Mauricio Galofre, funcionarios del IDU conjuntamente con Álvaro Dávila, Emilio Tapia y Julio Gómez manipularon la elaboración de los pliegos de condiciones para la licitación (...) igual sucedió frente a la habilitación y exclusión de propuestas en el proceso de evaluación, todo con el propósito de beneficiar a las uniones temporales conformadas por el grupo Nule.

Destaca la providencia en mención, la manipulación en la elaboración de los pliegos y en la oportunidad de evaluar y verificar las ofertas al habilitar y rechazar proponentes con la intención específica de beneficiarse; igualmente la suscripción de contratos aparentes o ficticios, con el único propósito de utilizarlos de canal para transferir parte del anticipo que terminaría en el pago de la comisión o soborno pactado previamente, práctica en la que utilizaron empresas del mismo tercero que representaba y ostentaba los intereses del congresista, que para el afecto suponían la ejecución de las 
obligaciones pactadas. Igualmente señaló la misma decisión:

Mauricio Galofre, como encargado de las licitaciones del grupo Nule, dijo que de Julio Gómez recibieron consejos sobre la forma de presentarse a la licitación, lo cual les posibilitó a los Nule participar cumpliendo todos los requerimientos, mucho más si los pliegos publicados por el IDU se hicieron ajustados a su medida.

Ahora, Julio Gómez explicó que los diálogos entre Diana Paola Patiño y Mauricio Galofre sucedieron en la fase de pre-términos, los cuales estaban colgados en la página del IDU y que como «información privilegiada» suministrada por Inocencio Meléndez llegaba a sus oídos, pudiéndose hacer con dichos pretérminos cálculos y anticipar posibles ataques a los demás proponentes, por ejemplo en el tema de los parafiscales, y así por «descarte» se lograría la adjudicación a sus empresas sin problema alguno (...)

En otras palabras, con los correos se revela que Mauricio Galofre y Diana Paola Patiño conocieron el contenido de los proyectos de pliegos o prepliegos de condiciones antes de su divulgación al público en general, introduciéndoles al interior del IDU los aspectos que para ellos eran importantes y les otorgaban algunas condiciones favorables respecto de otros aspirantes (...)

Señaló que como se formaron varios grupos para la asignación de los contratos, la estrategia era estar en la mayor cantidad de ellos para asegurar la adjudicación, toda vez que la escogencia a través de la media geométrica era prácticamente al «azar» (...)

En estas condiciones la información probatoria hasta ahora relatada, revela que el trámite diseñado al interior del IDU, el cual no obstante verificarse en los plazos y condiciones señalados en los artículos 30 de la Ley 80 de 1993, $9^{\circ}$ de la Ley 1150 de 2007 y los artículos 2 al 12 del Decreto 2474 de 2008, comprueba que la elaboración de los pliegos de condiciones se hizo a la medida de los contratistas (...)

Con lo anterior se acredita que quienes finalmente fueron escogidos como contratistas de dos de los seis grupos de la licitación (...) las uniones temporales GTM y Vías de Bogotá 2009-, lograron que los funcionarios del IDU, Liliana Pardo Gaona e Inocencio Meléndez Julio, con anticipación a la divulgación de los pliegos de condiciones definitivos hicieran los correctivos necesarios, siendo ésta una de las formas en que se materializó el acuerdo de voluntades entre los integrantes del grupo empresarial Nule, Julio Gómez, Álvaro Dávila y Emilio Tapia Aldana, estos últimos en calidad de emisarios y representantes de los intereses de NÉSTOR IVÁN MORENO ROJAS y su hermano Samuel, el Alcalde de Bogotá. 
Este proceder revela aún más el interés indebido que atentó contra los principios de imparcialidad, transparencia y selección objetiva, de que trata el artículo 24 de la Ley 80 de 1993, subrogado por el artículo 2 de la Ley 1150 de 2007 (...)

Tanto fue el sigilo y la apariencia de legalidad que el citado testigo Javier Horacio Pachón, señaló que procedimientos como llevar a los miembros de un comité evaluador a un hotel para allí "encerrados» y aislados del mundo exterior, como se hizo en el Hotel Bacatá, fueron novedosos para la Subdirección Técnica de Licitaciones y Concursos, lo que lleva a confirmar que se implementaron métodos aparentemente trasparentes pero que en realidad eran parte de la hábil estrategia de manipulación (...)

Tanta fue la sospecha de anormalidad en la audiencia de adjudicación, pero que con el ropaje de legalidad era muy difícil divisarla (...)

La providencia en cuestión, evidencia la facilidad de realizar las propuestas en consideración al pliego elaborado a la medida de los futuros participantes antes de su publicación, lo cual permitió conformar varios grupos para asegurar la adjudicación, práctica que resulta reprochable y contraria a los principios de moralidad, publicidad y transparencia, al convocar y adelantar un proceso con tintes de legalidad y aparente sujeción a las regulaciones normativas que incluso adoptó métodos novedosos que simulaban mayor transparencia. El fallo también precisó:

Sostuvo que dichas comisiones fueron pagadas parcialmente en razón a que los Nule habían malgastado los anticipos y sólo alcanzó para cancelarlas a través de dos ofertas mercantiles que sumaban 5.003 millones de pesos destinadas a las empresas GEOS CONSULTING de Emilio Tapia y otra a la CONSTRUCTORA INCA de su propiedad. Aclaró que los dineros de su empresa se los entregó personalmente y en efectivo a Emilio Tapia para que los trasladara a NÉSTOR IVÁN MORENO ROJAS sin saber si ello se hizo finalmente (...)

Este modus operandi no es extraño en quienes pretenden ocultarse, actuar a la sombra o no dejar rastro de sus comportamientos, mucho menos que existan personas a las que les conste su directa participación. Esto se refleja claramente en el presente caso cuando testigos como Emilio Tapia Aldana y Julio Gómez señalan en sus testimonios que NÉSTOR IVÁN MORENO ROJAS no acostumbraba a reunirse con nadie para hablar de esos temas, sino que los acuerdos y compromisos se hacían siempre a través de sus representantes. 
Julio Gómez concretamente dijo que para comprometerse a fin de «ayudar para que nos adjudicaran las licitaciones", el ex Senador nunca se reunió con él, pues los Moreno no se reunían con nadie, ya que para ello contaban con Emilio Tapia Aldana.

(...) tal como lo reveló Miguel Nule Velilla, lo que hace el entonces Congresista es exigirle la entrega de dos zonas aledañas a los centros de control operativo (CCO) que se construían en la carretera Bogotá-Girardot con el propósito de que la señora Lucy Luna de Moreno pudiera instalar en ellas estaciones de suministro de combustibles. La anterior exigencia vino acompañada, en palabras de Miguel Nule, de lo siguiente: «por qué poner en riesgo todo lo que hay en el distrito (sic) por unas simples áreas de uso exclusivo»(...)

Ahora, sobre las razones por las que no quedó consignado el pedido de Miguel Nule en las actas de la Junta Directiva de la Concesión, además de lo mencionado por Carlos Collins, ilustrativa es la justificación brindada por Mauricio Galofre, quien sostuvo: "pues son cosas que se manejan fuera del normal desarrollo de cualquier empresa y no sería lógico dejar en un acta algo que más adelante puede ser tomado de alguna manera como delito".

(...) la conducta de MORENO ROJAS (...) implicó el desconocimiento de los principios generales de la contratación, especialmente de los de igualdad, moralidad, trasparencia, imparcialidad y selección objetiva, que deben guiarlos procesos contractuales estatales (...)

Valerse de terceras personas para determinar la realización de la conducta con el evidente propósito de no verse relacionado directamente, así como para mantener un control sobre la delincuencia, son expresiones de una mayor planeación encaminada a lograr el éxito de su designio criminal y, por ende, una modalidad que demanda una condigna sanción (...)

De otra parte, se observa que NÉSTOR IVÁN MORENO ROJAS abusó de su cargo y de la preponderancia que la sociedad le había confiado al haberlo elegido como Senador de la República, quien influyó indebidamente en una servidora pública que fungía como cabeza de una institución central de la Capital del país encargada de su desarrollo urbano, menospreciando así el interés superior de la administración pública, como también los principios de la moralidad y la probidad que orientan el ejercicio de aquella.

La sentencia evidencia como prácticas que afectaron la transparencia de los procedimientos de contratación estatal, el financiar campañas políticas que se retribuirían mediante contratos públicos; el tráfico de influencias, la intermediación, el poder burocrático y el abuso del cargo; la organización y planeación criminal en el 
poder público a través de cadenas con la intervención de terceros con actos de representación; los acuerdos o pactos para garantizar adjudicación, que comprendían el manejo de información privilegiada, el direccionamiento de licitaciones, ajuste a pliegos previos a su publicación que restringían la participación tanto nacional como extranjera y la estructuración de grupos que cumplieran tales requisitos para presentar oferta; la determinación de comisiones y suscripción de supuestos subcontratos que no se realizaban, con el propósito de pagar las comisiones; la neutralización de organismos de control mediante comisiones; el ofrecimientos de dádivas para lograr adjudicación de contratos; la manipulación de habilitación y exclusión de ofertas en las evaluaciones; el manejo indebido de anticipos, lo cual afecto la ejecución de las obras; y la exigencias de zonas para establecer actividades económicas. Actos que se desarrollaron ajustados al ordenamiento y con ropaje de legalidad e implementación de métodos para garantizar la pulcritud, que impedía divisar el panorama real, por cuanto pretendían no dejar rastros por el modus preestablecido.

Igualmente, la Sentencia de septiembre 27 de 2012 de la Corte Suprema de Justicia, Sala de Casación Penal - Sala de Juzgamiento, con ocasión de la declaratoria de responsabilidad penal de German Alonso Olano Becerra, en el denominado también carrusel de la contratación o el cártel de contratación en Bogotá, evidenció:

Una elocuente muestra de tal situación (...) que de tiempo atrás se conoce como el "cvy", la refirió Jorge Luís García Arango, empleado del Grupo Nule (...) quien dijo que una vez quiso independizarse y montar su propia empresa, encontró un panorama oscuro en el tema de las licitaciones de Bogotá, inmoral y poco transparente, pues conforme a su propia experiencia, al tratar de conseguir contratos en entidades oficiales, resultó completamente infructuoso, llevándose como única enseñanza que "debía tenerse amigos políticos o personas pagas dentro de las entidades" para merecer una adjudicación (...)

Que su grupo se presentó (...) a la licitación pública del IDU para la construcción de la Fase III de Transmilenio (Calle 26). Licitación frente a la cual existía la posibilidad de que fuera declarada desierta, pues la otra propuesta fue descalificada y la del Grupo Nule no contaba con diseños, licencias, predios y redes, entre otros requisitos. Fue por ello que acudió al Representante OLANO BECERRA, de quien conocía era cercano a Julio Gómez, persona influyente en el IDU, para lograr salvar su propuesta (...) 
El grupo empresarial consolidó un acuerdo de voluntades para que la contratación se llevara sin tropiezos y a cambio se entregaría la suma de 3.500 millones de pesos. La mitad (...) estaría destinada a Julio Gómez y la otra para OLANO BECERRA; pago que se iría efectuando por intermedio de ofertas mercantiles de empresas designadas por cada uno de ellos: COTSCO fue señalada por JULIO GÓMEZ y PRODECOL por el congresista OLANO (...) los inconvenientes de la Unión Temporal radicaban en el incumplimiento de los requisitos de carácter financiero, los cuales fueron ajustados internamente en el IDU a través de Inocencio Meléndez, que les permitió adicionar el cupo de crédito (...) la entrega del dinero al congresista, la efectuó por intermedio de Mauricio Galofre (...)

También explicó (...) la necesidad de pagar una comisión con destino al Senador Iván Moreno y su hermano Samuel, el Alcalde Mayor de Bogotá, como también para el Contralor Distrital, a razón del $6 \%$ para los primeros y el $2 \%$ para el segundo. (...) la citada comisión del $2 \%$ para el Contralor Distrital, en ese entonces Miguel Ángel Moralesrussi, no llegó a su destino, razón por la cual éste empezó a presionarlos en ejercicio del control fiscal pero con amenazas dirigidas a la ejecución de las obras de Transmilenio sobre la Calle 26 (...)

Señaló Mauricio Galofre que frente a los contratos de Malla Vial (...) exigieron al Grupo Nule el pago del $8 \%$ del valor total de los dos contratos, a cambio de su adjudicación, 6\% para los hermanos MORENO y el 2\% para el entonces Contralor Distrital Moralesrussi, por lo que se acondicionaron los pliegos de condiciones y manipularon la escogencia del contratista. Sucesos en los que GERMÁN OLANO se limitó a intervenir como "garante" del cumplimiento de lo pactado (...)

La sentencia evidencia la manipulación de las evaluaciones y verificaciones con el único propósito de habilitar participantes que en principio no cumplían los requisitos fijados en el pliego, mediante prácticas de intermediación y tráfico de influencias, que derivan en las actuaciones de funcionarios del IDU para la época al pactar comisiones o sobornos. Igualmente la providencia precisó:

El comportamiento "folclórico", como la tesorera califica el registro contable de las cuentas bancarias de Miguel, Manuel y Guido Nule y Mauricio Galofre, especialmente caracterizado por el manejo de grandes sumas de dinero en efectivo, la llevó a tener especial cuidado para dejar constancias (...) a GERMÁN OLANO, persona que no conoce, se le hicieron cuatro giros que registró "informalmente" en la contabilidad como "pago de comisiones", acorde con lo que se le informaba por los señores Nule o Galofre. Un primer desembolso lo fue por el valor equivalente para la compra de 15 mil dólares; el segundo, por cien millones 
de pesos; $y$, los otros dos, cada uno por valor de 125 millones de pesos, a través de dos cheques girados de una cuenta del Banco Colpatria cuyo titular era Mauricio Galofre y cambiados en efectivo por Ervin Tovar, siendo entregado el dinero en efectivo a Mauricio Galofre (...)

De otra parte, Mauricio Galofre refirió que a propósito de los apoyos a OLANO BECERRA, se firmaron contratos "de prestación de servicios por comisión de éxito", los cuales, uno por valor de tres mil millones de pesos y otro por cuatro mil quinientos millones de pesos, fueron aportados al expediente y uno de los suscriptores, Luis Rafael Monterrosa Ricardo, representante legal de la firma MNV S.A, brindó su testimonio, señalando que aun cuando dijo no conocer al congresista, lo hizo por orden de Mauricio Galofre. (...) cuñado de GERMÁN OLANO, quien aparece firmando los contratos, sostuvo en declaración que a pesar de no conocer a los señores Nule ni tener relaciones comerciales o profesionales con sus empresas, los firmó por solicitud expresa de su familiar, pero siempre entendiendo que eran inexistentes (...)

En otras palabras, el interés superior de la administración pública que debía ser respetado por GERMÁN ALONSO OLANO BECERRA, quien para esa época ostentaba la condición de Representante a la Cámara electo por la circunscripción electoral de Bogotá, fue avasallado y puesto al servicio de intereses grupales cuyo principal objetivo era la obtención de jugosas ganancias económicas. Además, es claro que esa especial condición de Congresista la esgrimió, pero en desmedro de los valores que honran el ejercicio del servidor público como la moralidad, integridad, transparencia, igualdad y eficacia (...)

Ese agravio, que atenta contra la administración pública, deslegitima no sólo a quienes representan los intereses de los gobernados en la rama legislativa, sino colocan en serio desprestigio la actividad estatal en el desarrollo de obras públicas que deben estar inspiradas en los principios de confianza honradez, honorabilidad, transparencia y oportunidad para todos. Tan desviado proceder genera un clima de incertidumbre en el desarrollo de las demás actividades, pues dudará la ciudadanía que esos altos y nobles fines sean la guía de la contratación pública.

La providencia advierte como prácticas que afectaron la transparencia en la actividad contractual del Estado, el tráfico de influencias, la necesidad de amigos políticos o personas pagas para lograr la adjudicación y la intermediación; los ajustes en la etapa de evaluación para avalar requisitos; la determinación de comisiones; la neutralización de organismos de control mediante comisiones; el indebido manejo del anticipo, lo cual afecta la ejecución contractual; la suscripción de contratos inexistentes de servicios por comisión de éxito; y el ejercicio fiscal como consecuencia del incumplimiento en el 
pago de la comisión, lo cual afecta la naturaleza del organismo de control. Todo lo cual con aparentes matices de legalidad para encubrir tales operaciones.

Además, de la declaratoria de responsabilidad penal, el Consejo de Estado mediante sentencias de marzo de 2013 en los radicados 11001-03-15-000-2010-00786-00(PI) y 11001-03-15-000-2011-00125-00(PI) decretó la pérdida de investidura de los congresistas implicados, sentencias que determinan las prácticas indebidas en que incurrieron los representantes elegidos democráticamente.

Igualmente, el Tribunal Superior del Distrito Judicial, al resolver el recurso de apelación, confirmó la declaratoria de responsabilidad penal de los contratistas Nule por peculado por apropiación, en consideración al daño causado a la colectividad, decisión que fue objeto de casación ante la Corte Suprema de Justicia, asunto con número interno 39831 y que se encontraba al despacho a julio de 2015, fecha de finalización de la investigación.

Conforme a los informes de organismos y decisiones judiciales algunas de las prácticas que comúnmente se presentan en la actividad contractual del Estado, terminan por afectar la transparencia, por exigencias en ocasiones desproporcionadas o arreglo previo entre algunos proponentes y entidades estatales o actos de sobornos de diferentes manifestaciones, situaciones que se reconocen ampliamente en los informes de Transparencia por Colombia.

El capítulo, presenta una aproximación a prácticas de algunos actores en la actividad contractual que aparentemente se enmarcan en la legalidad y logran afectar la transparencia de los procedimientos relacionados con las compras públicas, con el propósito de contextualizar el problema planteado en la investigación. 


\section{Capítulo 4}

\section{El Fortalecimiento de la Política Pública}

El desarrollo de esta tesis ha verificado, como el Estado colombiano, para guardar armonía con las políticas y disposiciones internacionales, ha incorporado a partir del año 2007 en su derecho interno legislación y reglamentación con el propósito de fortalecer la publicidad, garantizar la transparencia, buscar una selección objetiva en los procesos de selección y mitigar los actos de corrupción, lo cual correspondería al derecho estático, al adoptar un sistema de normas que resulta común y general en los sistemas jurídicos implementados en otros países, para lograr estándares que aseguren la transparencia, el comercio internacional, la interacción de los sujetos, la buena gestión pública y la pulcritud de los actores en las compras gubernamentales.

La mutación del derecho interno, requiere fortalecer y diseñar una política integral que beneficie a los actores en los procesos contractuales, a la sociedad y al cambio de la imagen internacional del país por los fenómenos relacionados con prácticas indebidas, a través de estrategias que determinen el plan de acción y las metas a cumplir con indicadores que reflejen su seguimiento.

En consecuencia, el fortalecimiento y diseño de la política pública debe enfocarse en dos ejes transversales, el primero, la cultura de la legalidad, desde la pedagogía, en busca de la transparencia no solo en la gestión pública contractual sino en todos los actos del diario vivir de la persona en el contexto del país y global; y el segundo; la lucha frontal contra la impunidad en general y específicamente en la actividad contractual del Estado, de tal forma, que se impongan condenas ejemplarizantes que se equiparen a los valores derivados de una cultura de la legalidad para asegurar su permanecía en el tiempo.

El primero, la cultura de la legalidad, implica una revolución en la educación, desde la etapa preescolar, que fortalezca y afiance los valores, los principios y el respeto, en tres sentidos: por la persona y la familia; por la sociedad; y por las instituciones tanto 
administrativas como judiciales. Para tal cometido se requiere adoptar microcurrículos que permitan la construcción de competencias dirigidas a reflejar el papel de la persona en la familia, en la sociedad y en el desarrollo del país en el contexto global, lo cual se reflejará en actos realizados con prevalencia de la confianza, la lealtad, la honestidad y la buena fe.

El proceso debe iniciar con la formación de los educadores en todos los niveles, es decir, preescolar, básica, medía, pregrado y posgrado, para que se conviertan en multiplicadores y en su cotidianidad transmitan modelos de ética y moral, en busca de construir personas íntegras, toda vez que nada aporta a un país el tener sujetos profesionales o hábiles en un oficio, pero carentes de valores y principios.

En consecuencia, las estrategias deben ser progresivas, de tal forma que se articulen con el nivel de escolaridad y conformen las reglas que en la sociedad estructuran el "deber ser", al establecer modelos de conducta en las relaciones, en beneficio de la persona, de la sociedad y del país en el contexto global, lo cual aumentará el respeto por los demás, la calidad de vida, la confianza por las autoridades e instituciones, así como la competitividad y crecimiento económico del país.

En forma concomitante, se debe trabajar en fortalecer los modelos de ética y moral en los empleados o funcionarios de las empresas privadas (Transparencia por Colombia, 2012) y de las entidades públicas (PNUD, 2011), con el propósito de buscar un cambio de cultura, que minimice los actos de corrupción y por el contrario aumente la probidad en las gestiones propias de la empresa en el ámbito privado y de las instituciones estatales.

Estrategias que buscan minimizar la mentalidad del dinero fácil, por fenómenos atribuidos a la politiquería, a los sobornos y a la corrupción en general, que de manera específica han afectado a todos y al crecimiento del país, actos que resultan de las prácticas individuales y sociales, como se advierte de informes de organismos y jurisprudencia analizada en la investigación. 
Facilidad, también atribuida a políticas públicas ejecutadas en educación, simplemente adoptadas por cumplir exigencias internacionales, que dieron lugar a aumentar la cobertura sin infraestructura ni personal suficiente, así como a la posibilidad de la promoción automática, lo que desencadenó en esperar un resultado sin el menor esfuerzo. En las pruebas PISA de la OCDE, Colombia ocupó en el año 2012 (Consejo Privado de Competitividad, 2014) el puesto 62 entre 65, lo que implica un arduo trabajo en las próximas generaciones para lograr niveles por lo menos aceptables en las mediciones internacionales.

En materia contractual pública, subsiste, por la costumbre que se enmarca en la cultura de la ilegalidad, el conseguir fácil las cosas, mediante sobornos (Transparencia por Colombia, 2012) para lograr la adjudicación. Al punto de conformarse grupos que logran económicamente influenciar las decisiones de altos directivos estatales, los cuales tienen aceptación y acceso a las compras gubernamentales y privadas tanto en el nivel nacional como territorial e internacional, con el fenómeno del conocido soborno transnacional que tipifica la Ley 1474 de 2011.

Los tentáculos de tales grupos, son más perjudiciales a las instituciones y al erario por las estrategias utilizadas, (Transparencia por Colombia, 2012) los niveles que alcanzan y el poder que detentan al mantener una posición dominante, que logra sus objetivos en las compras gubernamentales a través de prácticas indebidas.

Además, tales grupos o personas con cultura desviada de los principios y valores, subsisten por la tolerancia y aceptación de ciertos individuos que los soportan, reconocen, respetan y en algunos eventos se benefician en forma indirecta con subcontratos, derivados de actos contrarios al ordenamiento, que diluyen la responsabilidad del contratista primigenio. Beneplácito que desencadena en el aumento de poder y codicia. Igualmente subsisten por la facultad de influenciar a personas y a funcionarios con el único propósito de lograr actos ilegales, como se advirtió en las sentencias de la Corte Suprema de Justicia. 
De esta forma el soborno, en la cultura de la ilegalidad, es un requisito previo en algunas relaciones contractuales (Transparencia por Colombia, 2008) tanto públicas como privadas, que la ley pretende corregir con facultades específicas a un supervisor en el contrato estatal, que además de vigilar, también responde por los incumplimientos, que en principio se atribuyen a la cuota de corrupción previa que afecta la ejecución del contrato, como se advierte en las Sentencias de la Corte Suprema de Justicia, en consecuencia, los objetos contractuales no se cumplen en debida forma, lo cual termina en demandas que desgastan a la administración de justicia por actos que pretenden mantener la impunidad y quebrantamiento de la igualdad ante la ley por el poder económico de obstrucción de la justicia como se advierte de la Convención de las Naciones Unidas contra la Corrupción, ratificada por Colombia mediante la Ley 970 de 2005.

Tales prácticas al generalizarse en una sociedad, se convierten en costumbre y en una cultura de la ilegalidad, que es aceptada y tolerada como normal, por cuanto constituye el propósito de alcanzar cotidianamente los fines perseguidos de una forma más fácil y rápida por influenciar a cuanta persona se requiera en beneficio propio y específico en materia contractual pública con la adjudicación de contratos.

La cultura de la legalidad se concreta en el autocontrol y en aplicar los conceptos determinados en el preámbulo y en el desarrollo de la Constitución Política de 1991 de justicia, dignidad, respeto, equidad, solidaridad y participación, que deberían reflejarse en las personas, las instituciones y las empresas, con la prevalencia de ética, buena fe, honestidad y moral.

En tal sentido, la nueva sociedad que resulte del proceso, conocerá y respetará las normas, apoyará y colaborará a las autoridades, por la confianza legitima que resulta y rechazará todo acto ilegal, al ser conciente del impacto de sus decisiones en el entorno personal y social. 
De esta forma se busca contrarrestar prácticas indebidas en la sociedad, que por costumbre se realizan bajo el entendido de que es normal, porque así se procede siempre, al punto de crear una cultura por la costumbre de la ilegalidad, que afecta ostensiblemente a la sociedad, por cuanto, quien no actúa de tal forma, no colabora y por consiguiente, es un estorbo en la estructura de la institución.

La estrategia converge en la corresponsabilidad (Transparencia por Colombia, 2008) del individuo, la empresa y la sociedad con el Estado, lo cual se reflejará en el respeto mutuo y en la construcción de una cultura de la legalidad generalizada y mancomunada, por el esfuerzo integral de los diferentes actores que responsablemente consienten en sus actos, conocen sus consecuencias o efectos y ajustan su proceder a las disposiciones con el único propósito de construir un mejor país en el que se reconocen buenas prácticas en todos sus actos, lo cual internacionalmente permitirá la calificación de Transparencia Internacional a niveles óptimos.

La corresponsabilidad implica la construcción de una cultura de la legalidad que involucre (Transparencia por Colombia, 2008) el concurso efectivo de las personas, las empresas privadas y las entidades públicas, con modelos que autodeterminen no implicarse, denunciar actos contrarios al ordenamiento jurídico y replicar las buenas prácticas, la ética y la honestidad en todos los espacios de convivencia.

El segundo eje, debe fortalecer la lucha frontal contra la impunidad en general y específicamente en la actividad contractual del Estado, en tres sentidos: a través de un efectivo control ciudadano; la prevención; y el fortalecimiento de la administración de justicia, con el propósito de sancionar, conforme al ordenamiento jurídico, a las personas inmersas en actos que atenten contra el erario, el interés general y los derechos de la comunidad.

El efectivo control ciudadano implica abandonar la indiferencia e indolencia y denunciar ante las autoridades competentes los presuntos actos que afecten a la comunidad por situaciones derivadas de la gestión pública contractual, en ejercicio de los deberes y 
obligaciones de la persona y del ciudadano conforme al numeral 7 del artículo 95 de la Constitución Política de "Colaborar para el buen funcionamiento de la administración de la justicia", lo que constituye asumir con responsabilidad y objetividad los deberes con respecto a la gestión pública, que al omitirse acarrean sanciones penales por no denunciar o por no rendir testimonio.

En forma concomitante y en desarrollo de la corresponsabilidad, que implica la articulación de autoridades, personas y empresas, se debe fortalecer en los entes públicos y en las entidades privadas, la prevención y mitigación de actos relacionados con sobornos, corrupción y prácticas contrarias al ordenamiento, con el objeto de generar valores, principios, modelos de ética y respeto en las diferentes actuaciones adelantadas en general y específicamente en la gestión pública contractual.

De tal forma que los valores sociales que se generen, no toleren a los individuos que infringen la norma; no compartan sus actuaciones; no reciban recursos que desangran al Estado y les reprochen socialmente por los actos que atentan contra el erario, el desarrollo de la comunidad, la competitividad del país y la imagen internacional, conforme a las mediciones de Transparencia Internacional.

En concordancia con lo anterior, la impunidad debe combatirse con una administración de justicia recta y eficaz, que adopte en el menor tiempo posible y con garantías procesales sanciones ejemplares, sin importar la condición o rango del investigado, es decir, una justicia en igualdad de condiciones para todo infractor, lo cual asegura la legitimidad y la confianza en las autoridades judiciales y permitirá mantener en el tiempo el primer eje, la cultura de la legalidad, por cuanto la ausencia de sanciones efectivas y rápidas (Transparencia por Colombia, 2012) constituyen una oportunidad de crecimiento del corrupto que afecta notablemente a la sociedad.

Se debe fortalecer en la política pública las estrategias que permitan desarrollar los dos ejes transversales propuestos, de tal forma que identifiquen el origen de las causas de corrupción y sus consecuencias, con el objetivo de cuantificar los recursos para 
incorporar el plan de acción, como inversión social. Igualmente, debe contemplar el seguimiento y evaluación, que permitirán establecer la permanencia de la política con resultados en el corto, mediano y largo plazo.

El fortalecimiento de la política pública debe involucrar en la agenda, la realidad de los actores en las compras gubernamentales, de una forma integral, lo cual posibilita la construcción de una sociedad inmersa en la cultura de la legalidad, que permitirá el tránsito de la mera teoría a una acción estatal que garantiza la participación de la sociedad civil y de los actores en la contratación del Estado.

La Política debe identificar los problemas y las acciones que buscan dar solución a los mismos o minimizarlos a niveles manejables y controlables, en consecuencia, se mutaría el ambiente detectado como problemático en las compras gubernamentales, mediante acciones y medios definidos por el Estado para transformar total o parcialmente a la sociedad.

La política debe priorizar, en el objeto, el alcance y los mecanismos de su implementación, el construir desde la identificación o reconocimiento de la realidad en los procesos de selección, de tal forma que permita caracterizar las conductas en la actividad contractual del Estado y determinar acciones de manera específica.

Asimismo la política debe formular, las alternativas o estrategias posibles para minimizar los actos de soborno o corrupción en la contratación pública, en el corto, mediano y largo plazo, los posibles riesgos a través de una matriz, construida a partir del análisis del problema o realidad en la participación en los procesos de selección, etapa en la que es fundamental involucrar a la sociedad civil y a los actores en el sistema de compras públicas.

Conforme a lo anterior, la estructura de la política en dos ejes, el primero, la cultura de la legalidad; y el segundo, la lucha frontal contra la impunidad, debe ir de lo general a lo 
particular o específico en la actividad contractual del Estado y desarrollarse de manera concomitante en el tiempo, para asegurar sus resultados en el mediano y largo plazo.

El fortalecimiento de la política, debe ser de rango nacional, para involucrar en su aplicación a todos los entes gubernamentales sometidos al Estatuto General de Contratación de la Administración Pública y a los de régimen especial, con especial refuerzo en lo territorial, para la caracterización de situaciones específicas de Colombia, que no son comparables con otros países, por lo que se requiere cualificar las situaciones particulares que incluso varían de un departamento o municipio a otro, para implementar las estrategias y acciones a emplear, de tal forma que se pase del papel a una real acción estatal y social.

La evaluación de la política debe ser permanente, mediante un seguimiento continuo, que permita valorar los indicadores planteados en las acciones o estrategias y la implementación de auto-evaluación y planes de mejoramiento, para asegurar el cumplimiento de las metas trazadas para el corto, mediano y largo plazo. El investigador determina que en el corto plazo involucra la implementación y aplicación en los próximos cinco (5) años; y en el menor, la nueva sociedad con fuerza de producción, nivel de escolaridad y de corresponsabilidad social como mínimo en diez (10) años, por cuanto se requiere de reestructurar no solo el sistema sino la sociedad en general, lo cual puede tardar décadas para resultados en el largo plazo.

El capítulo, presenta un modelo de estrategia con la intención de fortalecer las políticas públicas mediante dos ejes transversales que buscan la construcción de una sociedad inmersa en la cultura de la legalidad, capaz de entender sus actos y consecuencias, lo cual permitirá la recuperación de la confianza, el respeto y la legitimidad de las instituciones. 


\section{Capítulo 5.}

\section{Incidencia de las Buenas Prácticas en las Compras Públicas}

Las compras gubernamentales han ocupado espacios muy importantes en el ámbito internacional desde el Código de la Ronda de Tokio de 1979, que permitió adoptar el Acuerdo sobre Contratación Pública (ACP), el cual en sus diferentes versiones incorporó como estrategia en busca de la transparencia, el uso de medios electrónicos, la subasta y la buena gobernanza como pilar de desarrollo para prevenir prácticas corruptas. Adicionalmente el ACP vigente armoniza con la Ley UNCITRAL. ${ }^{22}$

Dado el impacto de las compras públicas en el contexto social y global, la Organización de Estados Americanos (OEA), el Banco Interamericano de Desarrollo (BID) y el Centro Internacional de Investigaciones para el Desarrollo (IDRC), apoyan a través de la Red Interamericana de Compras Gubernamentales (RICG) a los países del continente americano, con el propósito de aumentar la transparencia, implementar herramientas de tecnología y fortalecer las buenas prácticas gubernamentales. ${ }^{23}$

También, se advierte que la Ley Modelo de la CNUDMI sobre la Contratación Pública de la Comisión de Naciones Unidas para el Derecho Mercantil Internacional UNCITRAL, con el propósito de buscar la transparencia, la integridad, la confianza, la participación y la equidad en el proceso de adjudicación, adoptó como medios: la licitación; el uso de las tecnologías; la subasta inversa electrónica; y la promulgación de un código de conducta para el personal de compras públicas. ${ }^{24}$

La Organización para la Cooperación y Desarrollo Económico - OECD - (Sánchez, 2009) evidencia como algunas buenas prácticas internacionales (i) la transparencia y la rendición de cuentas, como claves para promover la integridad y la prevención de la corrupción en la contratación pública; (ii) la buena gobernanza, para asegurar una gestión eficaz de los recursos públicos; (iii) reducir riesgos; (iv) la licitación; (v) pautas de ética, que determinen prohibiciones así como conflictos de intereses; y (vi) análisis del sector. 
Colombia desde el año 2007 en su ordenamiento interno ha incorporado disposiciones que permiten la articulación con las normas internacionales, al posibilitar el comercio electrónico; la publicación del plan de compras de todos los entes que administran recursos públicos en un mismo sitio web; la obligación de rendición de cuentas; la creación de la Agencia Nacional de Contratación Pública - Colombia Compra Eficiente, como la autoridad que dirige las políticas contractuales, actualmente miembro de RICG; entre otros, pero persiste en la realidad de algunos sectores de la sociedad un panorama enmarcado en actos de corrupción que afectan la transparencia en la actividad contractual del Estado.

En el Ranking Nacional de Transparencia por Colombia, la nueva Agencia Nacional de Contratación Pública - Colombia Compra Eficiente - se encuentra en un nivel 'Alto' de riesgo de corrupción. (Transparencia por Colombia - ítn, 2015, p.14)

Si bien es cierto, que el artículo 4ํㅡ de la Ley 1450 de junio 16 de 2011, por la cual se expide el Plan Nacional de Desarrollo, contempló entre los pilares, programas y estrategias "el buen gobierno, lucha contra la corrupción y participación ciudadana", más cierto es que se requieren estrategias firmes y ajustadas a la realidad que demuestren resultados internos, que se reflejarán en las mediciones internacionales, toda vez que Colombia se ubicó en el año 2014 en la posición 94 del índice de Percepción de Corrupción de Transparencia Internacional, por tanto, se deben robustecer en la política pública las acciones y estrategias, con la implementación efectiva de buenas prácticas y la intervención de la sociedad civil, lo cual permitirá recuperar la confianza e inversión interna así como extranjera.

Se evidencia, que la misma Convención de las Naciones Unidas contra la Corrupción (CNUCC) considera esencial la participación del sector privado en la lucha contra la corrupción, por ende la legislación colombiana, en consonancia con los tratados y convenios internacionales suscritos, incorporó en la Ley 1474 de 2011 (Gaceta del Congreso de Colombia No. 607, 2010) mecanismos para la prevención de actos de 
corrupción y medidas penales en el ámbito público y privado, con tipos como la corrupción privada y el delito de administración desleal de la legislación española.

Se puede inferir de la presente tesis, que el solo marco normativo no es suficiente para garantizar la probidad y la transparencia en la contratación pública, por lo cual se requiere de la implementación efectiva de buenas prácticas internacionales, que como estrategia adoptó Barbados en sus procesos de compras gubernamentales, a través de medios electrónicos con el apoyo del Banco Interamericano de Desarrollo, que lo ubicó en la posición 15 en el índice de Percepción de Corrupción de Transparencia Internacional, como se observa en el capítulo II de la segunda parte de esta investigación. Lugar que logró (SELA, 2014) a pesar de no contemplar en su ordenamiento interno un marco normativo específico o autónomo que regulara las compras gubernamentales, por lo cual avanza en su adopción desde el año 2012.

En América Latina las políticas gubernamentales se han caracterizado por proteger a micro, pequeñas y medianas empresas en la contratación estatal, mediante disposiciones específicas para participar en las compras públicas, con el propósito de generar empleo, crecimiento en la economía y en la competitividad. (SELA, 2015)

En tal sentido y con la intención de masificar la participación de las mipymes no solo en el ámbito local sino regional, las políticas públicas deben enfocarse en un concepto de mipymes más amplio, que promueva e incentive su intervención, al punto de lograr erradicar la diferencia normativa en cada país al catalogar a la mipymes, con el propósito de involucrarlas no solo en la contracción pública nacional sino en la regional, lo cual requiere de un consenso de las naciones por lo menos vecinas, en el que se equiparen las reglas que permitan el acceso a las compras gubernamentales con una articulación normativa (SELA, 2015) en los parámetros de empleados, capital patrimonial y facturación para su clasificación.

Al respecto, la UE con el propósito de superar situaciones relacionadas con dificultades en el tamaño de los contratos, adoptó el Código Europeo de Buenas Prácticas para 
Facilitar el Acceso de las PYME a los Contratos Públicos, en el que incorporó medidas, entre las cuales se resaltan, la subdivisión de los contratos en lotes con modelos en Austria, Francia, Irlanda y Lituania; el acceso a información, a través de medios electrónicos; y las relacionadas con los requisitos financieros. (Comisión de las Comunidades Europeas, 2008)

Las políticas de la Estrategia Europa 2020, en relación con las compras gubernamentales se enfocan a (i) mejorar el acceso de las pymes a capital mediante la contratación pública; (ii) al uso eficaz de los fondos públicos y mercados con dimensión a toda Europa; y (iii) a fortalecer el gobierno electrónico con nuevas herramientas, como la relacionada con la facturación electrónica en la contratación pública, que se implementó con la Directiva 2014/55. Igualmente, se adoptará un marco jurídico para coordinar las obras públicas y modernizar la contratación pública, con disposiciones que incluso incentiven la innovación. (Comisión Europea, 2010)

En consecuencia, los ejes transversales de la política pública propuesta deben articularse con las buenas prácticas en la contratación indicadas por PNUD - 2011, la experiencia de otros países y las prácticas de organismos internacionales, con el propósito de consolidar líneas, que deben fortalecer la (i) formación de los funcionarios públicos en el ámbito nacional y territorial, en la dimensión de lo público y en el manejo de los recursos estatales; (ii) la planeación, para eliminar la improvisación; (iii) el tránsito del SECOP informativo al transaccional, para brindar mayor seguridad a los procesos; (iv) escoger los funcionarios encargados de la contratación por mérito, lo cual contribuye en la imparcialidad y neutralidad; (vi) propiciar la selección objetiva, al eliminar factores subjetivos para aumentar la participación; y (vi) en forma transversal, con estrategias, serias, contundentes y eficaces, en la cultura de la legalidad y la lucha contra la impunidad, como se esbozo en el capítulo anterior.

La formación de los funcionarios públicos debe contemplar estrategias que consoliden la actuación con principios y valores como la ética, honestidad y probidad, con el propósito de buscar la imparcialidad y rectitud en las decisiones adoptadas, así como el 
respeto, la lealtad a la institución y a la sociedad. Con especial énfasis en el nivel territorial, que en ocasiones cuenta con pocos profesionales o funcionarios que manejan temas contractuales y presupuéstales, lo que genera un eventual espacio de operación de los grupos corruptos. Además, se deben adoptar códigos de ética para los funcionarios públicos (Naciones Unidas, 2014) como lo recomienda la Convención de Naciones Unidas contra la Corrupción en su artículo 8ํㅡ, con estrategias claras que consoliden su aplicación eficiente.

Los medios electrónicos permiten optimizar trámites en la actividad contractual; aumentar los potenciales oferentes, lo cual favorece la competitividad y la escogencia; facilitan un adecuado control en línea e inmediato, por parte de la ciudadanía y los entes de control; brindan seguridad a los diferentes documentos digitales publicados, al generar alertas ante cualquier mutación; y proporcionan elementos para desarrollar procesos transparentes, públicos y confiables para todos los actores. Adicionalmente, los países deben posibilitar el paso de los portales informativos a los transaccionales como funcionan en Argentina, Brasil, Chile, Costa Rica y Perú, lo cual favorece la interacción y brinda mayor seguridad a las transacciones al realizarse en línea (CEPAL, 2010). Colombia adelanta sus primeros pasos en el nivel nacional a través de subastas electrónicas, pero debe intensificar las políticas públicas específicamente en lo territorial, de forma que se eliminen las brechas de ausencia de Estado, de gobiernos locales débiles y de pasividad de los residentes a los actos de corrupción, todo lo cual afecta el desarrollo y la competitividad.

La migración a la fase transaccional en el sistema electrónico de contratación, permitirá el auge del comercio electrónico en el territorio nacional, al posibilitar a través de medios electrónicos, la interposición de observaciones, la presentación de la oferta, la intervención en audiencias virtuales, la adjudicación por actos electrónicos y la expedición de pólizas electrónicas, entre otros.

Transparencia Internacional (TI) señaló, que Dinamarca ocupó el primer puesto en el índice de Percepción de la Corrupción 2014, con una profunda consolidación del 
estado de derecho; apoyo a la sociedad civil; normas que regulan la actuación de quienes cumplen funciones públicas; y la creación en noviembre de un registro público que brinda información sobre los beneficiarios finales en todas las sociedades constituidas en el país, con el propósito de desenmascarar a los corruptos ocultos en sociedades a nombre de terceros. Iniciativa que invita a seguir TI y que en similares condiciones anuncia Ucrania y el Reino Unido. ${ }^{25}$

El mismo índice determinó que en Latinoamérica los países con mejor calificación son Uruguay y Chile, con su plataforma ChileCompra; los acuerdo marco; el observatorio ChileCompra, ganador de la categoría innovación en la X Conferencia RICG realizada en Paraguay en el año 2014. ${ }^{26}$

Brasil organizó el Registro Empresas Pro-ética, que determina la responsabilidad de las empresas por actos de corrupción contra la administración nacional y extranjera, conforme al soborno transnacional que enmarca el artículo VIII de la Convención Interamericana Contra la corrupción, registro que EUROsociAL invita a implementar en otras latitudes.

Igualmente, Transparencia Internacional, reconoce que la ubicación en el índice de Chile y Uruguay se debe a los modelos judiciales rígidos, que son respetados por la sociedad y finalizan con sanciones ejemplarizantes a funcionarios gubernamentales por actos indebidos, lo que incide en que la corrupción se torne más difícil. En Chile se presentó una fusión entre la cultura y soluciones legislativas con resultados óptimos por décadas en la construcción de una sociedad capaz de repudiar y condenar actos ilegales. Modelo que Transparencia Internacional invita a seguir en Colombia, que pese a contar con disposiciones legales, debe fortalecer con la reglamentación, aplicación, vigilancia, seguimiento y efectividad judicial.

El mérito, (PNUD, 2011) como principio orientador para acceder a los cargos relacionados con funciones de contratación pública, favorecerá la imparcialidad, la 
neutralidad en el manejo de las diferentes actuaciones derivadas de la contratación estatal y la selección objetiva.

A título de ejemplo, los manuales adoptados, incluso por DAPRE, se refieren a la publicación "Buenas Prácticas de Transparencia en la Gestión Contractual" de PNUD, se limitan a transcribir apartes, pero realmente no existe eficacia en las estrategias adoptadas para su materialización, por lo tanto las políticas públicas deben ser más que un simple eslogan del gobierno de turno, por ajustarse o cumplir con exigencias internacionales. ${ }^{27}$

En la misma línea, la Guía para la Elaboración de Estudios del Sector de Colombia Compra Eficiente, simplemente se limita a indicar que la "importancia de realizar este análisis ha sido recalcada por las recomendaciones que la Organización para la Cooperación y Desarrollo Económicos le ha formulado al gobierno", por ende es hora de pasar del papel a una política pública real que evidencia resultados sin prebendas por rango o posición y que materialice los fines de las normas. ${ }^{28}$

En la misma línea, la Republica de China aprobó el 5 de mayo de 2015 la Ley que adopta la Convención de las Naciones Unidas contra la Corrupción, con el propósito de fortalecer la cultura de un gobierno limpio, la prevención y sanciones por prácticas corruptas, la recuperación de bienes ilegalmente adquiridos, así como la cooperación internacional.

El capítulo presenta, las buenas prácticas de organismos internacionales y de otras latitudes que han resultado exitosas y que Colombia en su mayoría ha incorporado, con el propósito de evidenciar que además de las regulaciones normativas y de los modelos seguidos, no se ha resuelto el problema jurídico planteado, por tanto se requiere no solo entender el sistema normativo sino aplicar el derecho efectivamente para lograr la construcción de una nueva sociedad. 


\section{Conclusiones}

En busca de una respuesta aproximada al problema jurídico planteado al inicio de esta tesis, se pueden efectuar los siguientes resultados:

Se colige por el desarrollo de la investigación, que la actividad contractual de las autoridades administrativas, en sus inicios se adelantaba con sujeción a la normatividad entre particulares, que permitía a los ordenadores del gasto disponer de los recursos públicos de manera discrecional (Rodríguez, 1977) y con absoluto poder en la asignación de los contratos.

Los primeros intentos normativos, permitieron (Palacio, 2003) a los departamentos y municipios en virtud de su autonomía, regular en sus estatutos fiscales elementos sobre la formación y adjudicación de contratos, lo que constituyó proliferación normativa.

A partir del texto de los antecedentes contractuales se advierte la estructuración de un conjunto de normas que distinguían los contratos privados de los públicos, que si bien regularon en forma especial los contratos de los entes estatales y la escogencia del futuro contratista, decayeron en exceso de disposiciones que diferían de un ente a otro, con exuberancia de trámites por la complejidad que se evidencia del estudio de las disposiciones, que comprendían el concepto del Consejo de Ministros, la aprobación del Presidente de la Republica y la revisión del Consejo de Estado previos a la ejecución contractual, según la norma vigente en la época.

El exceso de reglamentación y de controles que dilataban permitió proliferar la corrupción administrativa y supeditó la iniciación del contrato a realizar ajustes al presupuesto por aumento de costos (Matallana, 2009). Además, el cúmulo de disposiciones, la precaria celeridad y los inútiles así como excesivos controles generaron parálisis de la administración (Rico, 2009). Igualmente, la dispersión de la regulación resultaba contradictoria (Palacio, 2003). 
Las disposiciones que se adoptaron en el Estatuto General de Contratación de la Administración Pública - Ley 80 de 1993, intentaron unificar el marco legal y brindar las herramientas (Palacio, 2003) para atacar la corrupción y garantizar la moralidad en la actividad contractual, mediante la publicidad para garantizar la transparencia. La dispersión reglamentaria imperante en ese entonces, por el cúmulo de aproximadamente 40 decretos que regularon la materia hasta el año 2007, no favorecieron tales propósitos como lo encontró el investigador en el estudio normativo.

Entre las modificaciones legales al Estatuto, que iniciaron en el año 2007 con la Ley 1150 se resaltan, la incorporación de disposiciones internacionales; la inclusión de obligaciones derivadas de convenios o tratados internacionales; los mecanismos para fortalecer la selección del contratista, a través de unas modalidades que consideran el objeto del contrato; el fortalecimiento del principio de publicidad y transparencia con la implementación del Sistema Electrónico para la Contratación Estatal, en busca de una mayor publicidad de las convocatorias adelantadas para proveer bienes, obras y servicios. Aspectos que en su conjunto se orientaban a seleccionar la oferta más favorable al ente contratante en condiciones de rectitud, no solo de los servidores que intervienen en la adjudicación de recursos públicos, sino de todos los actores del proceso.

La investigación advierte que la Ley 1150 decayó en una reglamentación excesiva, que se modificó parcial y totalmente en varias ocasiones. Además, algunos artículos de los decretos del gobierno se suspendieron en forma provisional y posteriormente se decretó su nulidad por el máximo órgano de la jurisdicción contenciosa administrativa, por situaciones originadas en su formación que dieron lugar a extralimitaciones en las facultades otorgadas o ilegalidades. También, algunas disposiciones legales se declararon inexequibles, todo lo cual generó episodios de tránsito normativo, desconocimiento de los actores, inseguridad jurídica y por supuesto una oportunidad para realizar actos de corrupción, como se evidenció puntualmente en el desarrollo del trabajo por Transparencia por Colombia y el Consejo de Estado. 
El investigador encontró en las disposiciones, que los cambios normativos buscaban que las instituciones colombianas se fortalecieran, con el propósito de materializar la transparencia en las compras públicas, al garantizar los postulados de la función administrativa señalados en el artículo 209 de la Constitución Política, aplicables en la gestión pública contractual.

Infortunadamente el CONPES 167 de 2013, a pesar de reconocer la complejidad de la corrupción en Colombia y determinar que su costo, según la Auditoria General de la Republica, supera 10 billones de pesos en el presupuesto nacional y 4 billones en los entes territoriales, no contempló estrategias específicas en lo territorial. Simplemente apunta a reducir la dispersión normativa y a una mera difusión de buenas prácticas desde la Procuraduría General de la Nación, cuando en realidad el país requiere un cambio drástico en las conductas de las personas orientado desde una política integral que demuestre resultados.

Dispersión que intentó unificar el Gobierno Nacional con el Decreto 1082 de mayo 26 de 2015, por medio del cual se expide el Decreto Único Reglamentario del Sector Administrativo de Planeación Nacional, que lamentablemente conserva, por su carácter unificador, la posibilidad de expedir manuales, guías o circulares a Colombia Compra Eficiente, que constituyen una nueva forma de dispersión normativa y de concentración de poder que afecta la autonomía de los entes del nivel central.

A partir del horizonte normativo trazado, se puede concluir, que la Constitución de 1991 y el Estatuto General de Contratación de la Administración Pública en lo referente al desarrollo o regulaciones legales y reglamentarias en la actividad contractual del Estado, ha brindado unos instrumentos que fortalecen el principio de Transparencia como un primer intento de responder al problema jurídico planteado en esta tesis; se puede deducir entonces, que desde el punto de vista del derecho estático, las reformas fortalecen el postulado de publicidad al ordenar y disciplinar los procesos, en busca de mayor transparencia en la actividad contractual del Estado. 
La adopción de reglas especiales en los contratos públicos no garantizó la pulcritud en los procedimientos y conforme a los desarrollos del derecho administrativo, el volver a la aplicación de las normas entre particulares en las relaciones contractuales del Estado, implicaría el señalamiento de estrictos controles al manejo de recurso públicos, como elemento diferenciador, de un contrato celebrado en el sector privado, de uno público.

Con el propósito de generar prácticas de probidad en la gestión contractual gubernamental, se implementaron disposiciones de uso internacional que fortalecen el Principio de Transparencia adoptado en el Estatuto General de Contratación de la Administración Pública, tendientes a optimizar la publicidad y la posibilidad de utilizar las tecnologías de la información y las comunicaciones a través del Sistema Electrónico para la Contratación Pública. (SECOP)

Igualmente, el SECOP, es efectivo, contribuye a dinamizar la economía, disminuye costos asociados, reduce los tiempos, optimiza recursos y brinda seguridad en las operaciones, pero persiste, en algunos actores de la sociedad, tales como: servidores del Estado, particulares y empresarios, el panorama de sobornos y acuerdos previos a la adjudicación como lo advierte Transparencia por Colombia en los diferentes informes que documentaron la investigación y la Corte Suprema de Justicia en las sentencias de declaratoria de responsabilidad.

En el mismo sentido, se eliminaron trámites que hacían dispendiosa y compleja la contratación estatal, los cuales implicaban en algunos eventos, desde un análisis normativo, costos tanto para los interesados como para los entes públicos; y minimizar prácticas de pagos indebidos por trámites engorrosos o para obtener la adjudicación de contratos como lo advirtió en sus informes Transparencia por Colombia.

De acuerdo a los documentos estudiados persisten normas que contemplan regímenes especiales; multiplicidad de procedimientos en las causales de las modalidades de 
selección del supuesto Estatuto Único de Contratación; indebida planeación; y la proliferación de manuales, guías y circulares expedidas por Colombia Compra Eficiente. Todo lo cual, en su conjunto, mantiene (Transparencia por Colombia, 2015) el carácter de dispersión normativa por ajustes y diversidad de regímenes de contratación que favorecen el desorden y los riesgos de corrupción.

A partir de los informes y trabajos que documentaron la investigación la forma de combatir la corrupción, mitigar las violaciones al ordenamiento y aumentar la transparencia en la contratación pública, es fortalecer la ética, la honestidad, los principios y los valores, no solo de los servidores públicos y los empresarios, sino de la sociedad en general, a partir de su núcleo esencial, la familia, lo cual redundará en la confianza interna como externa del país. En consecuencia, las entidades públicas y las empresas privadas, en virtud de su función y responsabilidad social, deben propiciar actuaciones diáfanas y transparentes, que descarten la solicitud y ofrecimiento de dádivas. Los empresarios en su modelo de conducta, deben fortalecer las estrategias de sana competencia y la cultura empresarial contra el soborno.

También, se evidencia que el ofrecimiento de dádivas o sobornos en la etapa de selección, incide directamente en la ejecución del contrato, por cuanto los anticipos terminan en financiar los pagos de comisiones acordadas, lo que incide en la ejecución contractual.

Con las nuevas disposiciones el supervisor adquiere en la ejecución y liquidación del contrato un papel fundamental y complejo, por la politiquería y compromisos de algunos ordenadores del gasto público conforme a los informes de Transparencia por Colombia, que implican el cambio de cultura y recuperación de principios de todos los actores en el corto, mediano y largo plazo.

Se evidencia de los estudios, informes y jurisprudencia que documentaron la investigación que las constantes o prácticas que generan corrupción se concentran en la politiquería al acudir al cabildeo para obtener favores políticos que se retribuirán 
mediante contratos públicos; el tráfico de influencias, intermediación, poder burocrático y abuso del cargo; la organización y planeación criminal en el poder público a través de cadenas con la intervención de terceros con actos de representación; el manejo de información privilegiada, el direccionamiento de licitaciones, ajuste a pliegos previos a su publicación que restringían la participación y estructuración de grupos que cumplieran tales requisitos para presentar oferta; la determinación de comisiones; la neutralización de organismos de control mediante comisiones; el ofrecimiento de dádivas para lograr adjudicación de contratos; la manipulación de habilitación y exclusión de ofertas en las evaluaciones; en lo territorial por la pausada modernización y ausencia de Estado; y en el manejo indebido de anticipos, lo cual afecta la ejecución de obras; entre otros.

Tales prácticas, conforme a lo evidenciado por la Corte Suprema de Justicia al declarar responsabilidad, son planeadas y estructuradas, de tal forma que buscan guardar apariencia de legalidad al preordenarse con fachadas que simulan un desarrollo normal, mediante actos que presumen el cumplimiento de la ley así como los respectivos requisitos del proceso, con el firme propósito de quebrantar el ordenamiento jurídico y lesionar la transparencia en la actividad contractual del Estado.

Se evidencia entonces de la tesis, que la sola estructuración de disposiciones legales y reglamentarias no ha resuelto el problema jurídico planteado, en consecuencia, desde el punto de vista del derecho dinámico, implicaría el cambio de la sociedad a través de la cultura de la legalidad y la lucha frontal contra la impunidad con el objetivo de materializar la transparencia en la actividad contractual del Estado al erradicar prácticas que afectan su realización.

Las buenas prácticas, permitirán consolidar una cultura de la legalidad y la disminución de los niveles de impunidad de manera ejemplar, por la construcción colectiva y (Transparencia por Colombia, 2008) la corresponsabilidad entre personas, empresas y entes gubernamentales, que se reflejará en la confianza a las autoridades 
administrativas, a las decisiones judiciales y al respeto en los diferentes sectores de la sociedad, lo cual tendrá un efecto progresivo en las compras gubernamentales.

De tal suerte, que se materializará la transparencia, lo cual favorecerá ofrecimientos en condiciones de igualdad, que se compararán a través de criterios objetivos y previamente establecidos, sin mediar tráfico de influencias o prebendas para su adjudicación, lo que impactará en la disminución de los sobre-costos en la contratación asociados a prácticas indebidas. Adicionalmente y de presentarse situaciones contrarias al ordenamiento jurídico, serán sancionadas de forma ejemplarizante y eficaz, para mantener la cultura de la legalidad como eje fundamental de la transformación social.

Por tanto y en desarrollo de la corresponsabilidad, las empresas privadas deben fortalecer la generación de buenas prácticas, que permitan consolidar modelos de ética y de sana competencia en todas las relaciones concebidas, con el propósito de mitigar los actos de ofrecimientos de dádivas o entregas de las solicitadas para acceder a contratos en el sector público como privado.

El desarrollo de la tesis evidencia, del derecho estático y su concreción en el derecho dinámico, un paradigma caórdico (Hock, 2002), que demuestra como las disposiciones que buscan dar orden a la relación contractual pública, terminan ignoradas por prácticas indebidas de algunas personas, empresas y servidores del Estado, que en la mayoría de casos la sociedad acepta, encubre y no reprocha, lo cual constituye una sincronía aparente, que permite la materialización equilibrada de una cultura de la ilegalidad bajo la sombra de un ordenamiento jurídico que pugna por la legalidad y la validez.

Para finalizar, se puede colegir entonces, desde el punto de vista del derecho dinámico, que las reformas legislativas y reglamentarias al principio de publicidad para garantizar la transparencia, no han resuelto el problema planteado en esta investigación, por tanto se requiere fortalecer y diseñar una política pública integral, con el concurso y 
corresponsabilidad (Transparencia por Colombia) de las personas, la sociedad civil, las instituciones públicas, las autoridades judiciales, las empresas privadas y los diferentes actores en los procesos de contratación pública, que evidencien la transformación de la sociedad, en prácticas concordantes y concomitantes a modelos de valores, principios y moralidad; a la implementación y aplicación de buenas prácticas; a una cultura de la legalidad; y la lucha irrestricta contra la impunidad, lo cual contribuirá a fomentar la transparencia en las compras gubernamentales de forma significativa. 


\section{Referencias}

\section{General}

AJANI, Guianmaria, ANDERSON, Miriaam, ARROYO AMAYUELAS, Esther \& PASA, Barbara. (2009). Sistemas Jurídicos Comparados Lecciones y Materiales. España. Publicaciones i Edicions, Universidad de Barcelona.

ARIAS, Luis Federico. (2010). Ejercicio de la función pública: ética y transparencia. Argentina. Librería Editora Platense S.R.L.

BAUTISTA, Óscar Diego. (2009). Ética para Corruptos: Una Forma de Prevenir la Corrupción en los Gobiernos y Administraciones Públicas. España. Editorial Desclée de Brouwer.

CONSEJO DE ESTADO, COLOMBIA. Sección Tercera. M.P. SANTOFIMIO GAMBOA, Jaime Orlando. Sentencia de abril 20 de 2015, radicación número: 11001-03-26000-2014-00037-00(50219).

Sección Tercera. M.P. ANDRADE RINCÓN, Hernan. Sentencia de septiembre 10 de 2014. radicación número: 11001-03-26-000-2008-0004000(35362).

Sala de lo Contencioso Administrativo. M.P. RAMíREZ DE PAEZ, Bertha Lucia. Sentencia de marzo 19 de 2013, radicación 11001-03-15-0002010-00786-00(PI).

Sala de lo Contencioso Administrativo. M.P. GÓMEZ ARANGUREN, Gustavo Eduardo. Sentencia de marzo 12 de 2013, radicación 11001-03-15-0002011-00125-00(PI).

Sala de lo Contencioso Administrativo. Sección Tercera. C.P. GIL BOTERO, Enrique. Sentencia de abril 14 de 2010, radicación número: 11001032600020080010100 (36054).

Sala de lo Contencioso Administrativo, Sección Tercera. M.P. FAJARDO GÓMEZ, Mauricio. Providencia de febrero 04 2010, radicación número: 25000-23-26-000-1994-09827-01(16540). 
Sección Tercera. M.P. GIRALDO GÓMEZ, María Elena. Sentencia de junio 22 de 2000, expediente $N^{\circ} 12.723$.

CORTE CONSTITUCIONAL COLOMBIA. M.P. PRETELT CHALJUB, Jorge Ignacio. Sentencia de noviembre 14 de 2012, C-944.

2009, C-713.

. M.P. CALLE CORREA, Maria Victoria. Sentencia de octubre 07 de MP. CÓRDOBA TRIVIÑO, Jaime. Sentencia de marzo 08 de 2006, C172.

M.P. NARANJO MESA, Vladmiro. Sentencia de junio 02 de 1999, C400.

M.P. MORÓN DÍAZ, Fabio. Sentencia de agosto 05 de 1998, C-397.

CORTE SUPREMA DE JUSTICIA COLOMBIA. Sala de Casación Penal, Sala de Juzgamiento. M.P. CASTRO CABALLERO, Fernando Alberto. Sentencia octubre 27 de 2014 , radicado 34.382 .

- Sala de Casación Penal, Sala de Juzgamiento. M.P. CASTRO CABALLERO, Fernando Alberto. Sentencia septiembre 27 de 2012.

CRUZ MARTÍNEZ, Alexander. (2011). Intervención del Estado Colombiano en el Sector Solidario. Bogotá, Colombia. Editorial Universidad del Rosario.

CUELLO DUARTE, Francisco. (2009). Contratos de la administración pública. Colombia: Ecoe Ediciones.

DROMI, Roberto. (2008). Ecuaciones de los Contratos Públicos España. Ciudad Argentina Hispania Libros, 2ª edición.

EXPÓSITO VÉLEZ, Juan Carlos. (2005). La Configuración del Contrato de la Administración Pública en el Derecho Colombiano y Español. Análisis de la Selección de Contratistas. Bogota, Colombia. Universidad Externado de Colombia, Segunda Reimpresión. 
FERRARO, Carlo \& STUMPO, Giovanni. (2010). Políticas de Apoyo a las PYMES en América Latina: entre Avances Innovadores y Desafíos Institucionales. Chile. B CEPAL.

GARCÍA CUADRADO, Antonio. (2002). El Ordenamiento Constitucional. Un Enfoque Histórico y Formal de la Teoría Constitucional y de las Fuentes del Derecho. España. Editorial ECU.

GARCÍA DE ENTERRIA, Eduardo \& FERNÁNDEZ, Tomas Ramón. (2006). Curso de Derecho Administrativo I. Madrid, España. Civitas Ediciones, Décima Tercera Edición.

GONZÁLEZ RODRíGUEZ, Miguel. (2004). El Contencioso Contractual. Bogotá Colombia. Universidad Libre, 4를 Edición.

GÜECHÁ MEDINA, Ciro Nolberto. (2007). Contratos Administrativos. Bogotá Colombia. Grupo Editorial Ibáñez.

HOCK, Dee Ward. ( 2002). El Nacimiento de la Era Caórdica. España. Editorial Juan Granica S.A.

KELSEN, Hans. (2010). Teoría pura del derecho. Argentina. Eudeba.

LAFUENTE, Fernando. (2012). Aspectos del Comercio Exterior. España. Editorial BEUMED.

LAMPREA RODRíGUEZ, Pedro Antonio. (1979). Contratos Administrativos. Tratado Teórico y Práctico. Bogotá, D.E. Colombia. Imprenta y Publicaciones de las Fuerzas Militares.

MATALLANA CAMACHO, Ernesto. (2009). Manual de Contratación de la Administración Pública. Bogotá, Colombia. Universidad Externado, 2ª edición.

MELÉNDEZ, Marcela. (2015). Fortalecimiento de la Industria Local de Ingeniería. Cámara Colombiana de Infraestructura - Banco de Desarrollo de América Latina.

ORLER, José. (2010). El uso de encuestas en sociología jurídica. Los sondeos de opinión sobre la administración de justicia: posibilidad de un estudio CrossCountry en Argentina y España. Derecho y Ciencias Sociales. No. 2. Argentina. Red Instituto de Cultura Jurídica y Maestría en Sociología Jurídica. 
ORREGO LARRAÍN, Claudio. (2014). Corrupción y Modernización del Estado. Argentina. El Cid Editor, apuntes.

PALACIO HINCAPIÉ, Juan Ángel. (2003). La Contratación de las Entidades Estatales. Bogotá, Colombia. Librería Jurídica Sánchez R. Ltda. 4ª edición.

REGALADO HERNÁNDEZ, Rafael. (2007). Las MIPYMES en Latinoamérica. España. Editorial B - Eumed.

RICO PUERTA, Luis Alfonso. (2009). Teoría General y Oca de la Contratación Estatal. Bogotá Colombia. Editorial Leyer 6ํㅡㄹición.

RODRíGUEZ R., Gustavo Humberto. (1977). Contratos Administrativos - Código-. Bogotá D.E. Colombia. Editorial ABC.

ROSERO MELO, Bertha Cecilia. (2011). Contratación Estatal: Manual Teórico Práctico. Colombia. Ediciones de la U.

SÁNCHEZ GIL, Isabel. (2009). Integridad en la Contratación Pública Buenas Prácticas de la "A" a la "Z". Madrid, España. Instituto Nacional de la Administración Pública, Organización para la Cooperación y Desarrollo Económicos. (OECD)

SANTOFIMIO GAMBOA, Jaime Orlando. (2000). Delitos de celebración indebida de Contratos. Colombia. Universidad Externado de Colombia 1 edición.

SORIANO, Ramón. (2005). Sociología del derecho. Argentina. Editorial Ariel.

TRIBUNAL SUPERIOR DEL DISTRITO JUDICIAL, COLOMBIA. Sala Decisión Penal. M.P. FERNÁNDEZ CARLIER, Eugenio. Providencia de junio 01 de 2012.

VILLANUEVA HARO, Benito. (2012). Análisis Económico de la Corrupción. Argentina. El Cid Editor, apuntes.

\section{Documentos de Trabajo e Informes}

Banco Mundial. (2014). Doing Bussiness 2014 Entendiendo las Regulaciones para las Pequeñas $y$ Medianas Empresas. Recuperado de 
http://espanol.doingbusiness.org/ /media/GIAWB/Doing\%20Business/Documents/ Annual-Reports/Foreign/DB14-minibook-spanish.pdf

Cámara Colombiana de Infraestructura. (2012). Una Política Pública: Maduración de Proyectos Matriz de Riesgos Buenas Prácticas Contractuales. Bogotá, Colombia. Tercera Versión. Recuperado de http://www.infraestructura.org.co/nuevapagweb/ObservatorioContratacion/BUENA S\%20PRACTICAS.pdf

CEPAL. (2010). Avances en el Acceso y el Uso de las Tecnologías de la Información y la Comunicación en América Latina y el Caribe 2008 -2010. Naciones Unidas, Santiago de Chile. Recuperado de http://archivo.cepal.org/pdfs/2010/S2010189.pdf

Colombia Compra Eficiente. (2015). Guía para la Elaboración de Estudios del Sector. Recuperado de http://www.colombiacompra.gov.co/sites/default/files/manuales/cce_guia_estudio_ sector_web.pdf

Comisión Europea. (2010). Europa 2020 Una Estrategia para un Crecimiento Sostenible, inteligente e integrador. Bruselas. Recuperado de http://eurlex.europa.eu/LexUriServ/LexUriServ.do?uri=COM:2010:2020:FIN:ES:PDF

Comisión de las Comunidades Europeas. (2008). Código Europeo de Buenas Prácticas para Facilitar el Acceso de las PYME a los Contratos Públicos. Bruselas. Recuperado de http://ec.europa.eu/internal_market/publicprocurement/docs/sme_code_of_best_pr actices_es.pdf

Consejo Privado de Competitividad. (2014). Informe Nacional de Competitividad 2014 2015. Bogotá. Zetta Comunicadores. Recuperado de http://www.compite.com.co/site/wp-content/uploads/2014/11/CPC_INC-2014-2015Corrupcion.pdf

Convención Naciones Unidas. Programa de las Naciones Unidas para el Desarrollo PNUD. (2011). Buenas Prácticas de Transparencia en la Gestión Contractual. Primera impresión. Recuperado de http://www.pnud.org.co/img_upload/33323133323161646164616461646164/gobie rno/Libro\%20buenas\%20practicas.pdf 
Corporación Transparencia por Colombia. (2015). Colección de Documentos Observatorio de Integridad No. 16 Índice de Transparencia Nacional ítn 2013 2014. Bogotá Colombia. Recuperado de: http://www.indicedetransparencia.org.co/Portals/0/Documentos/ITN_Resultados_2 013-2014.pdf

Corporación Transparencia por Colombia. (2012). Colección Cuadernos de Transparencia No. 20 Tercera Encuesta Nacional sobre Prácticas contra el Soborno en Empresas Colombianas. Bogotá, Colombia. Gráficas Gilpor Ltda. Recuperado de http://www.anticorrupcion.gov.co/SiteAssets/Paginas/medicionesnacionales/cuaderno20_encuesta_practicas_contra_soborno_empresas.pdf

Corporación Transparencia por Colombia. (2008). Colección Cuadernos de Transparencia No. 15 Primera Encuesta Nacional sobre Prácticas contra el Soborno en Empresas Colombianas. Bogotá, Colombia. Gráficas Gilpor Ltda. Recuperado de http://www.anticorrupcion.gov.co/SiteAssets/Paginas/medicionesnacionales/cuaderno15_primera_encuesta_soborno.pdf

Corporación Transparencia por Colombia. (2011). Colección Documentos Observatorio de Integridad 12 ítn - Índice de Transparencia Nacional, resultados 2008- 2009. Bogotá, Colombia. Offset Gráfico Editores Ltda. Bogotá Colombia. Recuperado de http://www.anticorrupcion.gov.co/SiteAssets/Paginas/medicionesnacionales/\%C3\%8DNDICE\%20DE\%20TRANSPARENCIA\%20NACIONAL\%20R ESULTADOS\%202007-2008.pdf

Corporación Transparencia por Colombia. (2008). Colección Documentos Observatorio de Integridad No. 9 ítm Índice de Transparencia Municipal, resultados 2005 2006. Bogotá, Colombia. Offset Gráfico Editores Ltda. Recuperado de http://www.anticorrupcion.gov.co/SiteAssets/Paginas/medicionesnacionales/itm_2005-2006.pdf

Corporación Transparencia por Colombia. (2008). Colección Documentos Observatorio de Integridad No. 8 ítd - Índice de Transparencia Departamental, resultados 2005 - 2006. Bogotá Colombia, Gilpor Impresores. Recuperado de http://www.anticorrupcion.gov.co/SiteAssets/Paginas/medicionesnacionales/itd_2005-2006.pdf

Corporación Transparencia por Colombia. (2003). Colección Documentos Observatorio de integridad No. 2 Índice de Integridad de las Entidades Públicas Nacionales, resultados 2003.

Colombia.

Recuperado de 
http://www.anticorrupcion.gov.co/SiteAssets/Paginas/medicionesnacionales/indice_integridad_nacional2003.pdf

Departamento Administrativo Nacional de Estadística. (2009). Informe de Resultados 2008 Encuesta de Calidad de la Gestión Estatal para el Desarrollo Empresarial ECDE. Bogota Colombia. Recuperado de https://www.dane.gov.co/files/investigaciones/ecde/informe_ECDE_08.pdf

Naciones Unidas. (2014). Ley Modelo de la CNUDMI sobre la Contratación Pública. Recuperado de http://www.uncitral.org/pdf/spanish/texts/procurem/mlprocurement/2011-Model-Law-on-Public-Procurement-s.pdf

OCDE, Competition Committee. (2014). Combatiendo la Colusión en los Procesos de Contratación Pública en Colombia. Recuperado de http://www.oecd.org/daf/competition/2014_Fighting\%20Bid\%20Rigging\%20Colom bia_SPA.pdf

OECD. (2010). Convención para Combatir el Cohecho de Servidores Públicos Extranjeros en Transacciones Comerciales Internacionales y Documentos Relacionados. Recuperado de http://www.oecd.org/daf/antibribery/ConvCombatBribery_Spanish.pdf

ONU - Oficina de las Naciones Unidas contra la Droga y el Delito. (2004). Convención de las Naciones Unidas contra la Corrupción. Naciones Unidas, Nueva York. recuperado de https://www.unodc.org/documents/treaties/UNCAC/Publications/Convention/0456163_S.pdf

Presidencia de la República. (2014). Manual de Contratación. Bogotá. Recuperado de http://wsp.presidencia.gov.co/dapre/Documents/Contratos/Manual-ContratacionDAPRE-M-BS-01.pdf

Sistema Económico Latinoamericano y del Caribe - SELA. (2014). Las Compras Públicas como Herramienta de Desarrollo en América Latina y el Caribe. Venezuela. Recuperado de http://walk.sela.org/attach/258/EDOCS/SRed/2014/09/T023600006062-0-

Di_11_Compras_publicas.pdf

Sistema Económico Latinoamericano y del Caribe - SELA. (2015). Las Compras Públicas como Herramienta de Desarrollo en América Latina y el Caribe. 
Venezuela. Recuperado de http://www.sela.org/media/268508/las-compraspublicas-como-herramienta-de-desarrollo-en-alc.pdf

\section{Legislación, Disposiciones, Reglamentos y otros documentos}

Código de Procedimiento Administrativo y de lo Contencioso Administrativo, Legislación Complementaria. Legis. 2015.

Constitución Política de 1991 y Legislación Complementaria. Legis. 2015.

Constitución Política de 1886. Alcaldía Mayor de Bogotá D.C. Recuperado de http://www.alcaldiabogota.gov.co/sisjur/normas/Norma1.jsp?i=7153

Estatuto General de Contratación de la Administración Pública. Legis. 2015.

Consejo Nacional de Política, Económica y Social - CONPES 167. Estrategia Nacional de la Política Pública Integral Anticorrupción. 2013.

Consejo Nacional de Política, Económica y Social. CONPES 3249. Política de Contratación Pública para un Estado Gerencial. 2003.

Consejo Nacional de Política, Económica y Social. CONPES 3248. Renovación de la Administración Pública. 2003.

Consejo Nacional de Política, Económica y Social. CONPES 3186. Una Política de Estado para la Eficiencia y la Transparencia en la Contratación Pública. 2002.

Decreto Ley 019 de 2012, por el cual se dictan normas para suprimir o reformar regulaciones, procedimientos y trámites innecesarios existentes en la Administración Pública.

Decreto 1082 de mayo 26 de 2015, por medio del cual se expide el Decreto Único Reglamentario del Sector Administrativo de Planeación Nacional.

Decreto 1510 de 2013, por el cual se reglamenta el sistema de compras y contratación pública.

Decreto 1397 de 2012, por el cual se modifica el Decreto 734 de 2012 en lo relacionado con la capacidad residual. 
Decreto 734 de 2012, por el cual se reglamenta el Estatuto General de Contratación de la Administración Pública y se dictan otras disposiciones.

Decreto 2025 de 2009, por el cual se modifica parcialmente el Decreto 2474 de 2008 y se dictan otras disposiciones.

Decreto 2474 de 2008, por el cual se reglamentan parcialmente la Ley 80 de 1993 y la Ley 1150 de 2007 sobre las modalidades de selección, publicidad, selección objetiva, y se dictan otras disposiciones.

Decreto 066 de 2008, por el cual se reglamenta parcialmente la Ley 1150 de 2007 sobre las modalidades de selección, publicidad y selección objetiva y se dictan otras disposiciones.

Decreto 2434 de 2006, por el cual se reglamenta la ley 80 de 1993, se modifica parcialmente el decreto 2170 de 2002 y se dictan otras disposiciones

Decreto 2170 de 2002, por el cual se reglamenta la Ley 80 de 1993, se modifica el Decreto 855 de 1994 y se dictan otras disposiciones en aplicación de la Ley 527 de 1999.

Decreto 2150 de 1995, por el cual se suprimen y reforman regulaciones, procedimientos o trámites innecesarios, existentes en la Administración Pública.

Decreto 855 de 1994, por el cual se reglamenta parcialmente la Ley 80 de 1993 en materia de contratación directa.

Decreto 01 de 1984, por el cual se reforma el Código Contencioso Administrativo.

Decreto Ley 222 de 1983, por el cual se expiden normas sobre contratos de la Nación y sus entidades descentralizadas y se dictan otras disposiciones.

Decreto Ley 150 de 1976, por el cual se dictan normas para la celebración de contratos por parte de la Nación y sus entidades descentralizadas.

Decreto Ley 1670 de 1975, por el cual, se dictan normas para la celebración de contratos por parte de la Nación y sus entidades descentralizadas. 
Gaceta del Congreso de Colombia No. 607. Exposición de Motivos del proyecto de Ley 142 de 2010. 2010.

Gaceta del Congreso de Colombia No. 458. Exposición de Motivos del proyecto de Ley 20 de 2005. 2005.

Gaceta del Congreso de Colombia No. 75. Exposición de Motivos del proyecto de de Ley 149 de 1992. Colombia. 1992.

Ley 1508 de 2012, por la cual se establece el régimen jurídico de las Asociaciones Público Privadas, se dictan normas orgánicas de presupuesto y se dictan otras disposiciones.

Ley 1474 de 2011, por la cual se dictan normas orientadas a fortalecer los mecanismos de prevención, investigación y sanción de actos de corrupción y la efectividad del control de la gestión pública.

Ley 1450 de 2011, por la cual se expide el Plan Nacional de Desarrollo 2010 - 2014

Ley 1150 de 2007, por medio de la cual se introducen medidas para la eficiencia y la transparencia en la Ley 80 de 1993 y se dictan otras disposiciones generales sobre la contratación con Recursos Públicos.

Ley 80 de 1993, por la cual se expide el Estatuto General de Contratación de la Administración Pública.

Ley 167 de 1941, sobre organización de la jurisdicción Contencioso -administrativa.

\section{Sitios Web}

ec.europa.eu/europa2020/index_es.htm 26 /05/15. En (línea) 2015.

http://www.anticorrupción.gov.co/Paginas/comisionnacionalmoralizació.aspx, En (línea) 2005.

http://www.chilecompra.cl/. En (línea) 2015.

http://www.comprasgovernamentais.gov.br/. En (línea) 2015. 
http://www.contratos.gov.co. En (línea) 2015.

http://www.indicedetransparencia.org.co/. En (línea) 2015.

http://www.indicedetransparencia.org.co/Noticias/ArtMID/432/ArticleID/33/Caja-deHerramientas-Anticorrupci243n. En (línea) 2015.

http//www.mincit.gov.co. En (línea) 2015.

http://www.oas.org. En (línea) 2015.

http://www.oas.org/juridico/spanish/corr_ante.htm. En (línea) 2015.

http://www.oecd.org. En (línea) 2015.

http://www.oecd.org/about/history/. En (línea) 2015.

http://oecd.org/daf/competition/cartels/. En (línea) 2015

http://www.sia.eurosocial-ii.eu/actividad.php?id=2461, En (línea) 2015

http://wp.presidencia.gov.co/Paginas/Default.aspx, En (línea) 2015

http://www.ricg.org . En (línea) 2015.

www.transparenciacolombia.org.co. En (línea) 2014.

http:://www.transparency.org. En (línea) 2015.

http://www.transparency.org/news/pressrelease/indice_de_percepcion_de_la_corrupcio n_2014_el_crecimiento_transparente_en_r. En (línea) 2015.

http://www.uncitral.org/uncitral/es/uncitral_texts/procurement_infrastructure/2011Model.html. En (línea) 2015. 
https//www.unodc.org/pdf/corruption/publications_unodc_convention-s.pdf. En (línea) 2015.

https www.wto.org. En (línea) 2015.

https://www.wto.org/spanish/tratop_s/gproc_s/gp_gpa_s.htm. En (línea) 2015

https://www.wto.org/spanish/tratop_s/gproc_s/memobs_s.htm. En (línea) 2015

http://transparenciacolombia.org.co/es/noticias/indice-de-percepcion-de-corrupcion-2014 En (línea) 2015.

Radiografía de la Corrupción. En (línea) 2014. Fecha de Consulta (02 de diciembre de 2014)

Disponible

en: http://www.transparenciacolombia.org.co/index.php?option=com_content\&view=art icle\&id=106\&ltemid $=535$

\section{Bibliografía}

\section{General}

ARIAS, Alicia. (2011). Buenas Prácticas de Transparencia y Rendición Social de Cuentas en las que Intervienen las Organizaciones de la Sociedad Civil (OSC). Ecuador. Imprenta Nuevo Arte.

ARAÚJO RENTERÍA, Jaime. (1999). Principios de Derecho Constitucional. Bogota, Colombia. Editorial McGraw Hill.

BAUTISTA MOLLER, Pedro José. (1999). Contratos y Sanciones. Bogotá, Colombia. Ediciones Doctrina y Ley Ltda.

BENAVIDES, José Luis. (2004). El Contrato Estatal. Bogotá, Colombia. Universidad Externado de Colombia, $2^{\text {a }}$ Edición.

BETANCUR CUARTAS, Jaime. (2004). Nuevo Estatuto General de Contratación Pública. Medellín, Colombia. Biblioteca Jurídica Dike, 13ª Edición.

CARRILLO, Agustín. (2008) .e-Administración. España. Editorial UOC. 
CERRILLO MARTíNEZ, Agustí. (2014). El Principio de Integridad en la Contratación Pública. España. Editorial Aranzadi.

DAVILA VINUESA, Luis Guillermo. (2003). Régimen Jurídico de la Contratación Estatal. Bogotá, Colombia. Legis Editores, $2^{\mathrm{a}}$ edición.

DROMI, Roberto. (1995). Licitación Pública. Buenos Aires, Argentina. Ediciones Ciudad de Argentina, $2^{\underline{a}}$ Edición.

ESCOBAR GIL, Rodrigo. (1999). Teoría General de los Contratos de la Administración Pública. Bogotá, Colombia. Editorial Legis, Primera Edición.

EXPÓSITO VÉLEZ, Juan Carlos. (2009) .El Deber de Selección Objetiva. Bogotá, Colombia. Universidad Externado de Colombia.

FANDIÑO GALLO, Jorge Eliécer. (2014). La Contratación Estatal. Editorial Leyer.

FERNÁNDEZ ACEVEDO, Rafael \& VALCÁRCEL FERNÁNDEZ, Patricia. (2014). La Contratación Pública a debate: Presente y Futuro. Madrid, España. Editorial Civitas.

GIMENO FELEU, José Maria. (1995). El control de la Contratación Pública (Las normas comunitarias y su adaptación en España) Madrid, España. Editorial Civitas.

GÓMEZ LEE, Iván Darío. (2009).Contratación Segura. Estudio Normativo Compilatorio de la Contratación Estatal. Konrad Adenauer Stiftung - Instituto Seguridad Jurídica y Probidad. Primera Edición.

HENAO HIDRON, Javier. (2004). Panorama del Derecho Constitucional Colombiano. Bogotá, Colombia. Editorial Temis, 13ª edición.

LAMPREA RODRÍGUEZ, Pedro Antonio. (2007). Contratos Estatales. Bogotá, Colombia. Editorial Temis.

MABRAS GRANELL, Jordi. (2013). Las Empresas y el Sector Público: Cómo Vender a los Ayuntamientos. España. Editorial UOC.

MARIENHOFF, Miguel. (1992). Tratado de Derecho Administrativo. Buenos Aires, Argentina. Abeledo - Perrot Tomo III A 3 edición. 
MOLANO LÓPEZ, Mario Ernesto. (2009). La Nueva Estructura de los Procesos de Selectivos en la Contratación Estatal. Bogotá, Colombia. Ediciones Nueva Jurídica.

MORFIN, Antonio. (2015). Garantías y Apoyo al Comercio Exterior de las Pymes en América Latina. Naciones Unidas, Serie Financiamiento para el Desarrollo No. 255. Santiago de Chile.

NARANJO MESA, Vladimiro. (2010). Teoría Constitucional e Instituciones Políticas. Bogotá, Colombia. Editorial Temis.

PALACIO HINCAPIÉ, Juan Ángel. (2010). Derecho Procesal Administrativo. Bogotá, Colombia. Librería Jurídica Sánchez R. Ltda. $7^{a}$ edición.

PÉREZ ALEGRE, Virginia \& GARCÍA SERRANO, Javier. (2014). Ley de Contratos del Sector Público. España. Dykinson, 2ª ${ }^{\text {a }}$ ed.

PÉREZ ESCOBAR, Jacobo. (2010). Derecho Constitucional Colombiano. Bogotá Colombia. Editorial Temis, $8^{\mathrm{a}}$ edición.

PERNAS GARCÍA, José. (2013). Contratación Pública Estratégica. España. Editorial Aranzadi.

PINO RICCI, Jorge. (2005). El Régimen Jurídico de los Contratos Estatales. Bogotá, Colombia. Universidad Externado de Colombia.

REBELO DE SOUSA, Marcelo \& SALGADO DE MATOS, André. (2013). Derecho Administrativo General. Colombia. Leyer Editores, 1‥ ed., Tomo I.

RODRÍGUEZ RODRÍGUEZ, Libardo. (2013). Derecho Administrativo General y Colombiano. Bogotá, Colombia. Editorial Temis 18ª edición.

(2012). El Equilibrio Económico en los Contratos Administrativos. Bogotá, Colombia. Editorial Temis $2^{2}$ edición.

RODRÍGUEZ TAMAYO, Mauricio Fernando. (2013). Los Contratos Estatales en Colombia. Librería Jurídica Sánchez R. Ltda., 1ae edición. 
ROZENWURCEL, Guillermo \& BEZCHINSKY, Gabriel. (2012). Compras Públicas en América Latina y el Caribe. Diagnósticos y Desafíos. Argentina. Universidad Nacional de San Martín.

SANTOFIMIO GAMBOA, Jaime Orlando. (2009). Contracción Estatal - Legislación. Bogotá, Colombia. Universidad Externado de Colombia $2^{\underline{a}}$ edición.

(2004). Tratado de Derecho Administrativo, T. III, Contencioso Administrativo. Bogota, Colombia. Universidad Externado de Colombia.

(2004). Tratado de Derecho Administrativo, T. IV, Contratación Indebida. Bogota, Colombia. Universidad Externado de Colombia.

SOLANO SIERRA, Jairo Enrique. (2010). Contratación Administrativa. Bogotá, Colombia. Ediciones Doctrina y Ley, 4⿳ạ edición.

SOLARTE MAYA, Felipe Alirio. (2008). Contratos Estatales Atípicos. Ediciones Nueva Jurídica.

SOTOMAYOR URIBE, Oscar Augusto. (2013). Contratación Estatal. Bogotá, Colombia. Librería Ediciones del Profesional Ltda., 1aㅡ edición.

SUÁREZ BELTRÁN, Gonzalo. (2014). Estudios de Derecho Contractual Público. Legis Editores, $1^{a}$ edición.

URBINA SÁNCHEZ, Elisa, ACOSTA, Joaquín Emilio, DURÁN VINAZCO, Ricardo \& PALOMARES, Jorge Ricardo. (2012). Los Contratos en la Era Global. Bogotá, Colombia. Grupo Editorial Ibáñez - Universidad Santo Tomas.

YONG SERRANO, Samuel. (2012). EL Contrato Estatal en el Contexto de la Nueva Legislación. Bogotá, Colombia. Grupo Editorial lbáñez.

\section{Documentos Trabajos e Informes}

Consejo Privado de Competitividad. (2014) Índice Departamental de Competitividad 2014. Bogotá. Recuperado de http://www.compite.com.co/site/wpcontent/uploads/2014/10/IDC-2014.pdf 
Contraloría General de la Unión (CGU) - Instituto Ethos de Empresas y Responsabilidad Social. (2010). La Responsabilidad Social de las Empresas en el Combate a la Corrupción. Brasil. Recuperado de http://www.unodc.org/documents/lpobrazil/Topics_corruption/Publicacoes/Espanol-La-Responsabilidad-SocialEmpresas-Combate-Corrupcion.pdf

Ministerio de Tecnologías de la Información y las Comunicaciones, Programa Gobierno en línea. (2010). Cartilla de Introducción al Sistema Electrónico para la Contratación Pública. Tercera edición.

Organización de Estados Americanos - Agencia Interamericana para la Cooperación y Desarrollo. (2003). Programa Mejores Prácticas Perfiles de Sistemas Electrónicos Gubernamentales. Recuperado de https://www.oas.org/es/cidi/AICD.asp

Organización Mundial del Comercio. Acuerdo Sobre Compras del Sector Público. Recuperado de https://www.wto.org/spanish/docs_s/legal_s/tokyo_gpr_s.pdf

Red Interamericana de Compras Gubernamentales - Universidad Nacional de San Martín. (2012). La Dimensión Internacional de la Contratación Pública. Recuperado de http://www.unsam.edu.ar/escuelas/politica/ideas/ICT4GP/Doc17\%20Compras-

Dimension-Internacional.pdf

Corporación Transparencia por Colombia. (2015). Colección de Documentos Observatorio de Integridad No. 15 Índice de Transparencia Departamental 2013 2014. Bogotá Colombia. Recuperado de: http://www.indicedetransparencia.org.co/Portals/0/Documentos/ITD_Resultados_2 013-2014_my26.pdf

Corporación Transparencia por Colombia. (2015). Colección de Documentos Observatorio de Integridad No. 14 Índice de Transparencia Municipal 2013 - 2014. Bogotá Colombia. Recuperado de: http://www.indicedetransparencia.org.co/Portals/0/Documentos/ITM_Resultados_2 013-2014_may_26.pdf

Corporación Transparencia por Colombia. (2010) Colección Cuadernos de Transparencia No. 19 Segunda Encuesta Nacional sobre Prácticas contra el Soborno en Empresas Colombianas. Bogotá, Colombia. Gráficas Gilpor Ltda. 
Recuperado de http://www.anticorrupcion.gov.co/SiteAssets/Paginas/medicionesnacionales/cuaderno19_segunda_encuesta_soborno.pdf

Naciones Unidas. (2002). Ley Modelo de la CNUDMI Sobre Firmas Electrónicas. Austria. Recuperado de http://www.uncitral.org/pdf/spanish/texts/electcom $/ \mathrm{ml}$ elecsig-s.pdf

Oficina de las Naciones Unidas contra la Droga y el Delito. (2013) Programa anticorrupción de ética y cumplimiento para las Empresas: Guía Práctica. Naciones Unidas, Nueva York. Recuperado de https://www.unodc.org/documents/corruption/Publications/2013/1385255_Ebook.pdf 


\section{Notas}

1 Consulta: https://www.wto.org/spanish/tratop_s/gproc_s/gp_gpa_s.htm, en (línea) 2015.

2 lbídem.

3 Ibídem.

4 Consulta: www.ricg.org, en (línea) 2015.

5 SELA, 2014.

6 Consulta: http://www.uncitral.org/pdf/spanish/texts/procurem/ml-procurement/2011Model-Law-on-Public-Procurement-s.pdf, en (línea) 2015.

7 Consulta: https://www.wto.org/spanish/tratop_s/gproc_s/gp_gpa_s.htm, en (línea) 2015.

8 Consulta: https://www.wto.org/spanish/tratop_s/gproc_s/gpa_1994_s.htm, en (línea) 2015.

9 Consulta: https://www.wto.org/spanish/tratop_s/gproc_s/memobs_s.htm, en (línea) 2015.

10 Consulta: http://www.oas.org/juridico/spanish/corr_ante.htm, en (línea) 2015.

11 Consulta: www.oas.org/JURIDICO/SPANISH/TRATADOS/B-58.HTML, en (línea) 2015.

12 Consulta: http://www.oecd.org/about/history/, en (línea) 2015.

13 Consulta: http://www.oecd.org/daf/competition/cartels/, en (línea) 2015.

14 Consulta: http://www.anticorrupción.gov.co, en (línea) 2015.

15 Ibídem.

16 Ibídem.

17 Consulta: www.transparenciacolombia.org.co, en (línea) 2015.

18 Consulta: http://www.sia.eurosocial-ii.eu/actividad.php?id=2461, en (línea) 2015.

19 Ibídem.

20 Consulta: http://oecd.org/daf/competition/cartels/, en (línea) 2015.

21 Ibídem.

22 Consulta: https//www.wto.org, en (línea) 2015.

23 Consulta: www.ricg.org, en (línea) 2015.

24 Consulta: http://www.uncitral.org, en (línea) 2015.

25 Consulta:

http://www.transparency.org/news/pressrelease/indice_de_percepcion_de_la_corrupcion 2014_el_crecimiento_transparente_en_r, en (línea) 2015.

26 Consulta: www.ricg.org, En (línea) 2015.

27 Consulta: http://wsp.presidencia.gov.co/dapre, en (línea) 2014.

28 Consulta: www.colombiacompra.gov.co, en (línea) 2014. 